\title{
Severnaya Zemlya, Arctic Russia: a nucleation area for Kara Sea ice sheets during the Middle to Late Quaternary
}

\author{
Per Möller ${ }^{\mathrm{a}, *}$, David J. Lubinski ${ }^{\mathrm{b}}$, Ólafur Ingólfsson ${ }^{\mathrm{c}}$, Steven L. Forman ${ }^{\mathrm{d}}$, \\ Marit-Solveig Seidenkrantz ${ }^{\mathrm{e}}$, Dimitry Yu. Bolshiyanov ${ }^{\mathrm{f}}$, Hanna Lokrantz ${ }^{\mathrm{g}}$, \\ Oleg Antonov ${ }^{\mathrm{h}}$, Maxim Pavlov ${ }^{\mathrm{f}}$, Karl Ljung ${ }^{\mathrm{a}}$, JaapJan Zeeberg ${ }^{\mathrm{i}}$, Andrei Andreev ${ }^{\mathrm{j}}$ \\ ${ }^{a}$ GeoBiosphere Science Centre, Department of Geology, Quaternary Sciences, Lund University, Sölvegatan 12, SE-22362 Lund, Sweden \\ ${ }^{\mathrm{b}}$ Institute of Arctic and Alpine Research (INSTAAR), Campus Box 450, University of Colorado, Boulder, CO 80309-0450, USA \\ ${ }^{\mathrm{c}}$ Department of Geology and Geography, Askja, University of Island, IS-101 Reykjavik, Iceland \\ ${ }^{\mathrm{d}}$ Department of Earth and Environmental Sciences, University of Illinois at Chicago, 845 W. Taylor Street, Chicago, IL 60607-7059, USA \\ ${ }^{\mathrm{e}}$ Department of Earth Sciences, University of Aarhus, C.F. Mollers Allé 120, 8000 Århus, Denmark \\ ${ }^{\mathrm{f}}$ Arctic and Antarctic Research Institute (AARI), 38 Bering Street, St. Petersburg 199397, Russia \\ ${ }^{\mathrm{g}}$ Geological Survey of Sweden, Villavägen 18, P.O. Box 670, SE-75128 Uppsala, Sweden \\ ${ }^{\mathrm{h}}$ VSEGEI (A.P. Karpinsky All Russia Research Geological Institute), 74 Sredny Prospect, St. Petersburg 199106, Russia \\ ${ }^{i}$ Netherlands Institute for Fisheries Research (RIVO), Postbus 68, 1970 AB IJmuiden, The Netherlands \\ ${ }^{\mathrm{j}}$ Alfred-Wegener-Institut für Polar- und Meeresforschung, Forschungsstelle Potsdam, Telegrafenberg A43, 14473 Potsdam, Germany
}

Received 24 July 2005; accepted 26 February 2006

\begin{abstract}
Quaternary glacial stratigraphy and relative sea-level changes reveal at least four expansions of the Kara Sea ice sheet over the Severnaya Zemlya Archipelago at $79^{\circ} \mathrm{N}$ in the Russian Arctic, as indicated from tills interbedded with marine sediments, exposed in stratigraphic superposition, and from raised-beach sequences that occur at altitudes up to $140 \mathrm{~m}$ a.s.l. Chronologic control is provided by AMS ${ }^{14} \mathrm{C}$, electron-spin resonance, green-stimulated luminescence, and aspartic-acid geochronology. Major glaciations followed by deglaciation and marine inundation occurred during MIS 10-9, MIS 8-7, MIS 6-5e and MIS 5d-3. The MIS 6-5e event, associated with the high marine limit, implies ice-sheet thickness of $>2000 \mathrm{~m}$ only $200 \mathrm{~km}$ from the deep Arctic Ocean, consistent with published evidence of ice grounding at $\sim 1000 \mathrm{~m}$ water depth in the central Arctic Ocean. Till fabrics and glacial tectonics record repeated expansions of local ice caps exclusively, suggesting wet-based ice cap advance followed by cold-based regional ice-sheet expansion. Local ice caps over highland sites along the perimeter of the shallow Kara Sea, including the Byrranga Mountains, appear to have repeatedly fostered initiation of a large Kara Sea ice sheet, with exception of the Last Glacial Maximum (MIS 2), when Kara Sea ice did not impact Severnaya Zemlya and barely graced northernmost Taymyr Peninsula.
\end{abstract}

(C) 2006 Elsevier Ltd. All rights reserved.

\section{Introduction}

Knowledge of spatial and temporal variations of past Eurasian High Arctic ice sheets is essential for reconstructing Quaternary climates, constraining sea level, ocean current fluctuations and the flux of freshwater to the Arctic Ocean (Peltier, 1994; Weaver, 1995; Forman et al., 2000). Extensive field research over the past 15 years, evaluated

\footnotetext{
${ }^{*}$ Corresponding author. Tel.: + 46462229888 ; fax: + 46462224419 .

E-mail address: per.moller@geol.lu.se (P. Möller).
}

and summarized in Svendsen et al. (2004) and used as a basis for modelling by Siegert and Dowdeswell (2004), has led to reconstructions of a substantially larger ice sheet in the Barents Sea (BSIS) than the Kara Sea (KSIS) during the Last Glacial Maximum (LGM) (Fig. 1). There is also a growing consensus that successively smaller ice volumes repeatedly occupied the Kara Sea basin since Marine Oxygen Isotope Stage 6 (MIS 6).

Despite the recent progress, uncertainty remains on the reconstruction of ice extent and ice dynamics of LGM and pre-LGM ice sheets in the Kara-Barents Seas regions, 


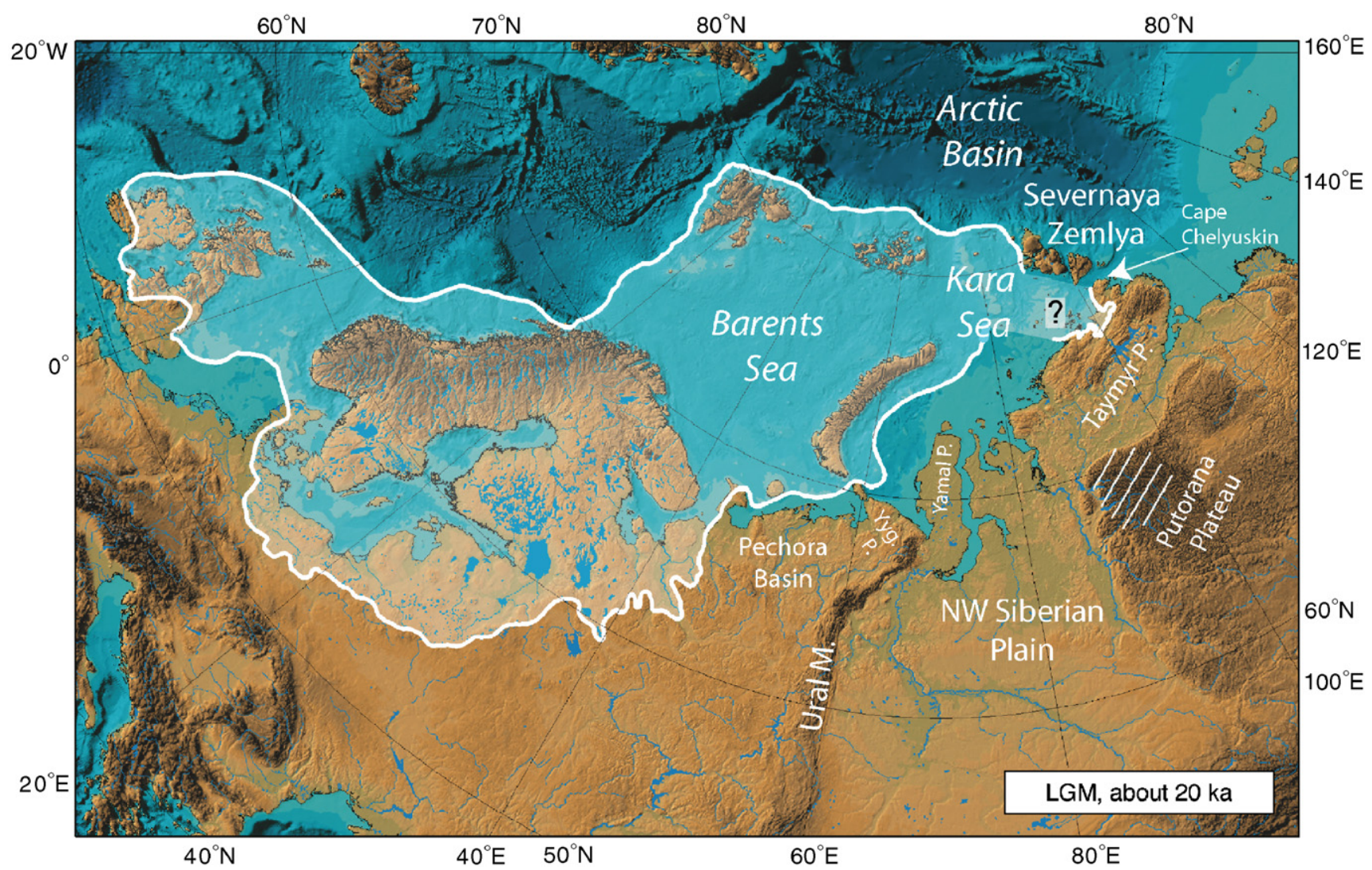

Fig. 1. The configuration of Eurasian ice sheets at the LGM (reprinted from Quaternary Science Reviews, 23/11-13, Svendsen et al. (2004), with permission of Elsevier Science).

especially in the enigmatic northern Kara Sea and its adjacent land areas. Ice from the northern portions of this region clearly flowed southward onto low-lying coastal areas of north-western Taymyr Peninsula (Fig. 1) between 20 and $12 \mathrm{ka} \mathrm{BP}$ (Alexanderson et al., 2001) but there is little record of a source for this ice to the north or a dynamic connection to the Barents Sea Ice Sheet across the deep Saint Anna Trough. Marine core data from the Kara Sea continental slope show a paucity of ice-rafted debris (IRD) during the LGM (Knies et al. 2001). A recent lake core study from October Revolution Island, Severnaya Zemlya (Fig. 1), yielded a similar result: there is no evidence for an LGM ice sheet overriding the lake site (Raab et al., 2003).

Even larger uncertainties exist with reconstructions of the extent and ice dynamics of pre-LGM ice sheets in the northern Kara Sea region because the records are often fragmentary, difficult to date, or distal to the ice margin. Möller et al. (1999a) and Alexanderson et al. (2002) concluded that northern Taymyr were subjected to extensive glaciations in Early to Middle Weichselian times (ca 90-80 and 70-60 ka BP; MIS 5 and 4), but evidence of older glaciations is sparse. Evidence of multiple preLGM glaciations is also present on Severnaya Zemlya (Bolshiyanov and Makeyev, 1995). However, the deposits have not yet been fully documented and conclusively dated. Marine records from the deep continental slope to the north are more complete than those from adjacent land areas. IRD peaks suggest KSIS advances onto the outer shelf, probably to the shelf edge, during MIS 6, 5d-a and 4, of which the MIS 4 Kara Sea glaciation is regarded to be the most extensive during the Weichselian (Knies et al., 2001). The MIS 6 glaciation appears to have been even more extensive given evidence for ice grounding on the $1000 \mathrm{~m}$ deep Lomonosov Ridge by a thick ice shelf or enormous icebergs at this time (Jakobsson et al., 2001; Polyak et al., 2001). Understanding the ice sheet geometry associated with this grounding event has been difficult because of the paucity of MIS 6 data from ice-proximal areas on the shelves and adjacent land areas. Ice dynamics for such an event and smaller glaciations in the region are no doubt complicated and influenced by external factors like the inflow of Atlantic Water to the Arctic basin, which provides critical moisture to the ice sheets. Arctic Ocean foraminifer abundance records suggest strong Atlantic inflows before the MIS 6, MIS 5b, and late MIS 4/early MIS 3 glaciations (Spielhagen et al., 2004).

The Severnaya Zemlya archipelago (Fig. 2) is situated in a proximal region for reconstructing the extent and dynamics of LGM and pre-LGM ice sheets in the northern Kara Sea region. Its southernmost island lies less than $100 \mathrm{~km}$ north of the Taymyr Peninsula, with its record of Kara ice impacting low coastal areas during the LGM (Alexanderson et al., 2001). The hitherto paucity 


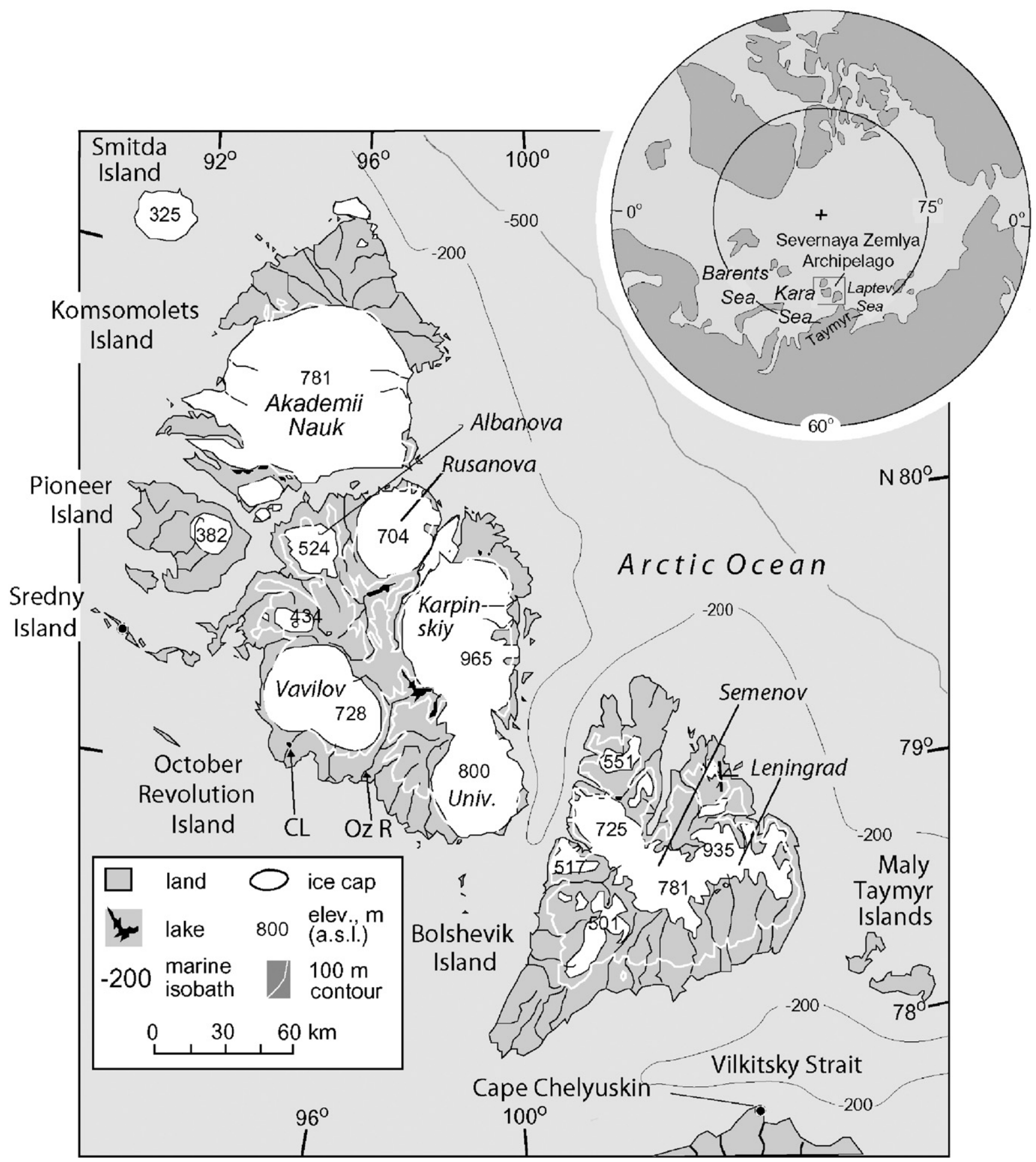

Fig. 2. The Severnaya Zemlya archipelago consists of more than 30 islands, situated on the Siberian continental shelf. Separated by the Vilkitsky Strait, Severnaya Zemlya lies immediately north of Cape Chelyuskin, the most northerly point of northern Eurasia. The four major islands, October Revolution, Bolshevik, Komsomolets, and Pioneer, cover a total area of about $37,000 \mathrm{~km}^{2}$ of which October Revolution Island is the largest island in the archipelago $\left(14,170 \mathrm{~km}^{2}\right)$. Our main studied sites in the Changeable Lake (CL, arrow) and the Ozernaya River $(\mathrm{Oz}$ R, arrow) areas are both situated south of the Vavilov Ice Cap on southern October Revolution Island.

of well-dated glacial-geologic and stratigraphic data from Severnaya Zemlya confounds delimiting whether this archipelago was inundated by the Kara Sea ice sheet, or supported local glacier expansion with large areas remaining ice-free during most glacial cycles. Evidence of past glaciations on Severnaya Zemlya is fragmentary (Bolshiyanov and Makeyev, 1995) and obvious glacial landforms, such as sculptured landscapes of different scales, moraine ridge systems, eskers and glacial striae are scarce. The discovery of mammoth bones (Mammuthus primigenius) on 
Severnaya Zemlya, yielding ${ }^{14} \mathrm{C}$ ages of $29.9-12.3 \mathrm{cal} \mathrm{ka} \mathrm{BP}$ (Table 4), have been interpreted either to signify preclusion of a LGM ice sheet over the archipelago (Velichko et al., 1984; Bolshiyanov and Makeyev, 1995) or to indicate transport of these bones to the islands by a northward advancing ice sheet (Grosswald, 1998). Recently, Raab et al. (2003) presented results from a sediment core retrieved from Changeable Lake on October Revolution Island (Fig. 3), situated only $\sim 4 \mathrm{~km}$ from the present Vavilov Ice Cap margin. Based on ${ }^{14} \mathrm{C}$ and luminescence ages of the lake succession above a basal diamicton it was concluded that the latest glacier expansion into this basin occurred prior to ca $53 \mathrm{ka}$. This was followed by a marine inundation, regression and desiccation of the lake basin, in turn followed by lacustrine sedimentation under cold and arid climate conditions ca $20 \mathrm{ka}$ ago, with higher sediment input during the warmer and wetter conditions at the Pleistocene-Holocene transition. The sedimentary succession in Changeable Lake suggests that southern October Revolution Island was outside the margin of the Barents-Kara Sea ice sheet during the LGM (Raab et al., 2003).

Bolshiyanov and Makeyev (1995) describe a long and complex stratigraphy (their field site 29) along the Ozernaya River on southern October Revolution Island (Fig. 2). There, a 47-m-thick succession was found to contain fossiliferous marine sediments and interbedded diamictons. Several subfossil shells from the marine sediments yielded conventional ${ }^{14} \mathrm{C}$ ages near or beyond the upper limit of this method ( $>43 \mathrm{ka} \mathrm{BP})$, and three ESR ages suggested deposition of the strata from $58 \mathrm{ka}$ to $>170 \mathrm{kaBP}$. The genesis of the diamict units is not well constrained but Bolshiyanov and Makeyev (1995) recognize signatures of possibly three different glaciations in the sequence; at the base of the section a glacial deposit (their 1st unit) is inferred to relate to a Middle Pleistocene glaciation, whereas the 5th and 7th units are diamictons interbedded with marine sediment and are considered to be glaciomarine in origin. Makeyev and Bolshiyanov (1986), Makeyev et al. (1992) and Bolshiyanov and Makeyev (1995) also describe raised beaches reaching $>100 \mathrm{~m}$ a.s.l. on October Revolution and Komsomolets Islands with age constrained by 14 conventional ${ }^{14} \mathrm{C}$ ages of associated marine fossils. Molluses and driftwood collected from raised beaches above $\sim 25 \mathrm{~m}$ a.s.l. yield ${ }^{14} \mathrm{C}$ ages of $>30-40 \mathrm{ka} \mathrm{BP}$, whereas molluscs from terraces at $\sim 25-15 \mathrm{~m}$ a.s.l. gave apparently younger ages of ca $28-21 \mathrm{ka}$ BP. Many of these ages were measured in the 1970s and 1980s, when detection of contamination by modern carbon and mixing of individual molluses of differing ages was not possible. Bolshiyanov and Makeyev (1995) conclude that the higher raised beaches may not necessarily reflect glacial isostasy, but recent tectonic movements. This opinion is inconsistent with the low historical seismicity of Severnaya Zemlya (e.g. USGS 1975-1995 data) and the lack of reported field evidence for neotectonism. We thus conclude that the age and genesis of glacial, fluvial, lacustrine and raised-marine sediment records on Severnaya Zemlya are inadequately

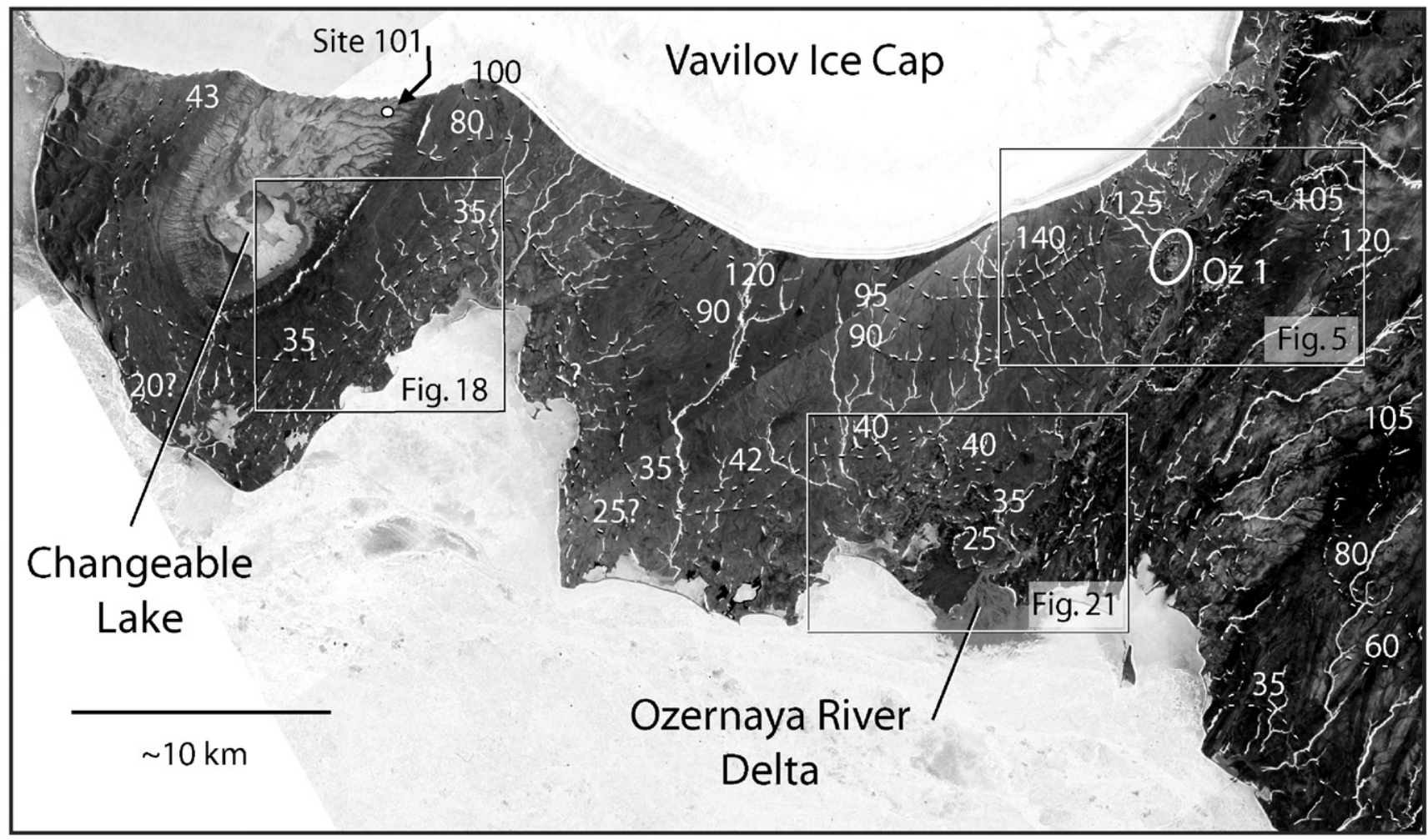

Fig. 3. Corona satellite image of southern October Revolution Island. Boxes mark positions for Figs. 5, 18 and 21 . The white circle marked 101 shows a site from Bolshiyanov and Makeyev (1995). 
constrained, and most stratigraphical sites have limited chronologic control and thus merit thorough reinvestigations.

The focus of our investigations was the stratigraphic and geomorphic record of three study areas on southwestern October Revolution Island, visited in 2002 and 2003 (Fig. 3). We employed morphologic, sedimentologic, stratigraphic and geochronologic techniques to help constrain glacier loading events that are preserved in the marine sediments and raised beaches up to $140 \mathrm{~m}$ a.s.l., highlight the significance of diamictons that occur repeatedly in stratigraphic sections and decide if they reflect local or Kara Sea-based glaciations during periods of Quaternary ice expansion. We also focused on collecting stratigraphic and geomorphic data that could relate to a possible LGM glaciation over Severnaya Zemlya.

\section{Geography and geology of Severnaya Zemlya and October Revolution Island}

The Severnaya Zemlya archipelago is situated on the Siberian continental shelf (Fig. 2) with four major islands, the October Revolution, Bolshevik, Komsomolets, and Pioneer Islands. October Revolution Island bedrock is Cambrian to Devonian in age, primarily consisting of Ordovician and Silurian limestones in the study area (Blieck et al., 2002). The bedrock outcrops over large areas, but is elsewhere covered by a relatively thin blanket of Quaternary deposits and periglacial regolith (Bolshiyanov and Makeyev, 1995). The geomorphology is characterized by broad valleys and extensive flat lowlands below $100 \mathrm{~m}$ a.s.l., transected by a number of river valleys and ravines of which the largest are those of the rivers draining the Vavilov and Karpinskiy Ice Caps (Fig. 2).

The present climate is high arctic (Vaikmäe et al., 1988), with an annual mean air temperature of $\sim 14{ }^{\circ} \mathrm{C}$ below zero. Only during 2 months, July and August, does monthly temperature average rise above $0{ }^{\circ} \mathrm{C}$. The summer climate is extremely windy, with a high frequency of storms from the Kara Sea, alternating with katabatic winds from the ice caps in summer (Bolshiyanov and Makeyev, 1995). The annual precipitation on October Revolution Island varies between 240 and $400 \mathrm{~mm}$, with most of the precipitation falling as snow on the ice caps (Andreev et al., 1997), though snowstorms can occur during the summer months. The ice caps of Severnaya Zemlya Island (Fig. 2) are coldbased, relatively thin $(<750 \mathrm{~m})$, and the ice cores that have been drilled to bedrock lack evidence to effectively constrain LGM or pre-LGM conditions (e.g. Kotlyakov et al., 2004).

\section{Methods}

Fieldwork was conducted in the Changeable Lake and Ozernaya River areas on southern October Revolution Island during July-August 2002 and 2003. Geomorphic observa- tions were combined with sedimentological assessment, glaciotectonic analyses and geochronological investigations.

Mapping - Satellite images, aerial photographs, and 1:500000 topographic maps were used to map marine terrace surfaces, raised beaches, and large sediment exposures over broad areas of October Revolution and Bolshevik Islands (Figs. 3, 5, 18, 21). Imagery included a Landsat 5 TM scene (1985/07/24, $30 \mathrm{~m}$ spatial resolution), numerous KH-4A Corona photographs (mission 1022-1, $1965 / 07 / 20, \sim 3 \mathrm{~m}$ resolution), and stereo aerial photographs for portions of the field areas (1952 and 1985). Image-based interpretations were refined in the field with a barometric altimeter $( \pm 2 \mathrm{~m})$, controlled against river-base levels and other points taken from 1:100 000 topographic maps.

Stratigraphic analyses - We concentrated on laterally extensive sections and targeted geochronological sampling. Logging was mostly at 1:10 scale using standardized lithofacies codes (Table 1). Diamicton fabric analyses were based on 25 clasts with longest axis $1-4 \mathrm{~cm}$ and $a / b$-axis ratios $>1.5$. All structural data were statistically evaluated, the fabric data according to the eigenvalues method (Mark, 1973).

Foraminiferal analyses - Samples from five sections were processed at the University of Aarhus using 75-100 g of dry sediment and sieve sizes of 63, 100 and $1000 \mu \mathrm{m}$ (cf FeylingHanssen 1983). A minimum of 300 specimens were identified in the $100-1000 \mu \mathrm{m}$ fraction, concentrated with a heavy liquid $\left(1.8 \mathrm{~g} / \mathrm{cm}^{3}\right)$. The $63-100 \mu \mathrm{m}$ fractions were

Table 1

Lithofacies codes (1st, 2nd and 3rd order code system) and their descriptions as used in this work (basic system according to Eyles et al., 1983)

\begin{tabular}{|c|c|}
\hline $\begin{array}{l}\text { Lithofacies } \\
\text { code: }\end{array}$ & $\begin{array}{l}\text { Lithofacies type description: Grain size, grain support } \\
\text { system, internal structures }\end{array}$ \\
\hline $\mathrm{D}(\mathrm{G} / \mathrm{S} / \mathrm{Si} / \mathrm{C})$ & $\begin{array}{l}\text { Diamicton, gravelly, sandy, silty or clayey. One or more } \\
\text { grain-size code letters within brackets }\end{array}$ \\
\hline $\mathrm{D}() \mathrm{mm}$ & Diamicton, matrix-supported, massive \\
\hline $\mathrm{D}($ )ms & Diamicton, matrix-supported, stratified \\
\hline $\mathrm{Co}-$ & Cobbles, as below \\
\hline $\mathrm{D}(\mathrm{)mm}(\mathrm{ng})$ & Diamicton, matrix-supported, massive, normally gradec \\
\hline $\mathrm{D}(\mathrm{mm}$ (ig) & Diamicton, matrix-supported, massive, inversely graded \\
\hline $\mathrm{D}($ )mm (ing) & $\begin{array}{l}\text { Diamicton, matrix-supported, massive, inverse to } \\
\text { normally graded }\end{array}$ \\
\hline Gmm & Gravel, matrix-supported, massive \\
\hline Gcm & Gravel, clast-supported, massive \\
\hline Gc(ng) & Gravel, clast-supported, normally graded \\
\hline Gc(ig) & Gravel, clast-supported, inversely graded \\
\hline $\mathrm{Sm}$ & Sand, massive \\
\hline $\operatorname{Sm}(n g)$ & Sand, massive, normally graded \\
\hline $\operatorname{Sm}(\mathrm{ig})$ & Sand, inversely graded \\
\hline Spp & Sand, planar parallel-laminated \\
\hline Spc & Sand, planar cross-laminated \\
\hline Stc & Sand, trough cross-laminated \\
\hline $\mathrm{Sr}$ & Sand, ripple-laminated \\
\hline $\mathrm{Sl}(\mathrm{def})$ & Sand, laminated, deformed \\
\hline $\operatorname{Sim}$ & Silt, massive \\
\hline Sil & Silt, laminated \\
\hline
\end{tabular}


Table 2

List of foraminiferal taxa mentioned in text and figures

Benthic foraminiferal taxa

Astrononion gallowayi (Loeblich and Tappan, 1953)

Buccella frigida (Cushman, 1922)

Buccella frigida calida (Cushman and Cole, 1930)

Buccella hannai arctic (Voloshinova, 1960)

Buccella tenerimma (Brady, 1950)

Cassidulina reniforme (Nørvang, 1945)

Cibicides lobatulus (Walker and Jacob, 1798)

Elphidium albiumbilicatum (Weiss, 1954)

Elphidium asklundi (Brotzen, 1943)

Elphidium bartletti (Cushman, 1933)

Elphidium excavatum, forma clavata (Cushman, 1930)

Elphidium hallandense (Brotzen, 1943)

Elphidium incertum (Williamson, 1858)

Elphidium ustulatum (Todd, 1957)

Eoeponidella pulchella (Parker, 1952)

Epistominella takayangii (Iwasa, 1955)

Epistominella vitrea (Parker, 1953)
Glabratella arctica (Scott and Vilks, 1991)

Haynesina depressula (Walker and Jacob, 1798)

Haynesina nivea (Lafrenz, 1963)

Haynesina orbiculare (Brady, 1881)

Islandiella helenae (Feyling-Hanssen and Buzas, 1976)

Islandiella inflata (Gudina, 1966)

Islandiella islandica (Nørvang, 1945)

Islandiella norcrossi (Cushman, 1933)

Miliolida

Stainforthia loeblichi (Feyling-Hanssen, 1954)

Trifarina angulosa (Williamson, 1858)

Trifarina fluens (Todd, 1947)

Planktonic foraminiferal taxa

Neogloboquadrina pachyderma (sinistral) (Ehrenberg, 1981)

Table 3

AMS ${ }^{14} \mathrm{C}$ ages from investigated sites on October Revolution Island, Severnaya Zemlya, Russia (for location of sites, see Figs. 5, 18 and 21 )

\begin{tabular}{|c|c|c|c|c|c|c|c|c|c|c|}
\hline Sites work & Sample no. & Dated material & Sed. unit & Sample/sea & evel $\mathrm{m}$ a..s.l. & Lab no. & Conv. ${ }^{14} \mathrm{C}$ age & Reserv. cor. ${ }^{14} \mathrm{C}$ age & $\delta{ }^{13} \mathrm{C}$ & Cal ka BP \\
\hline Changeable Lake 1 & CL $1 a^{1}$ & Mollusc & M-IV & 34.5 & ca 35 & CURL-6936 & $38690 \pm 260$ & $38250 \pm 260$ & $1.0 \%$ & $42673 \pm 262$ \\
\hline Changeable Lake 1 & CL $1 a^{2}$ & Mollusc & M-IV & 34.5 & ca 35 & LuS-5907 & $38400 \pm 1000$ & $37960 \pm 1000$ & & $42640 \pm 484$ \\
\hline Changeable Lake 3 & CL 3 & Mollusc & M-IV & ca 35 & ca 35 & LuS-5903 & $34000 \pm 600$ & $33560 \pm 600$ & & $39432 \pm 1243$ \\
\hline Changeable Lake 4 & $\mathrm{CL} 4 \mathrm{a}^{1}$ & Mollusc & M-IV & ca 35 & ca 35 & LuS-6904 & $38200 \pm 1000$ & $37760 \pm 1000$ & & $42541 \pm 467$ \\
\hline Changeable Lake 4 & $\mathrm{CL} 4 \mathrm{a}^{2}$ & Mollusc & M-IV & ca 35 & ca 35 & LuS-5905 & $31800 \pm 600$ & $31360 \pm 600$ & & $36576 \pm 645$ \\
\hline Changeable Lake 5 & CL $5 \mathrm{a}^{1}$ & Mollusc & M-IV & 28.5 & ca 31 & CURL-6937 & $44160 \pm 330$ & $43720 \pm 330$ & $0.5 \%$ & $46653 \pm 1430$ \\
\hline Changeable Lake 5 & CL $5 \mathrm{a}^{2}$ & Mollusc & M-IV & 28.5 & ca 31 & LuS-5906 & $42100 \pm 1600$ & $41660 \pm 1600$ & & $45008 \pm 1363$ \\
\hline Changeable Lake 5 & CL 5b & Mollusc & M-IV & 29.7 & ca 31 & CURL-6938 & $44350 \pm 490$ & $43910 \pm 490$ & $0.7 \%$ & $46825 \pm 1473$ \\
\hline Ozernay River 1a & $\mathrm{Oz} 1 \mathrm{a} / 26$ & Mollusc & M-II & 69.4 & $>70$ & CURL-6939 & $>54700$ & $>54260$ & $0.9 \%$ & Noncor. \\
\hline Ozernay River $1 \mathrm{~b}$ & $\mathrm{Oz} 1 \mathrm{~b} / 4$ & Mollusc & M-III & 79.3 & ca 82 & CURL-6940 & $49920 \pm 480$ & $49480 \pm 480$ & $2.8 \%$ & $50841 \pm 902$ \\
\hline Ozernay River 1d & $\mathrm{Oz} 1 \mathrm{~d} / 2$ & Mollusc & M-III & 81.7 & ca 82 & CURL-6941 & $>54700$ & $>54260$ & $1.3 \%$ & Noncor. \\
\hline Ozernay River le & $\mathrm{Oz} 1 \mathrm{e} / 17$ & Wood & M-I & 65.7 & $>66$ & CURL-6942 & $>51000$ & $>50560$ & $-27.9 \%$ & Noncor. \\
\hline Ozernay River 2 & SZ 02-32 & Mollusc & M-III & 98.5 & ca 100 & CURL-6948 & $44350 \pm 470$ & $43910 \pm 470$ & $2.5 \%$ & $46825 \pm 1469$ \\
\hline Ozernay River 2 & SZ 02-33 & Mollusc & M-III & 98.5 & ca 100 & CURL-6949 & $51710 \pm 460$ & $51270 \pm 460$ & $-0.6 \%$ & Noncor. \\
\hline Ozernay River 4 & $\mathrm{Oz} 1 \mathrm{f} / 10$ & Bone & M-IV & ca 54 & $>54$ & CURL-6943 & $49530 \pm 500$ & $49090 \pm 500$ & $-11.7 \%$ & $50422 \pm 1035$ \\
\hline Ozernay River 5 & SZ03-112(b) & Mollusc & & 57.3 & $>60$ & CURL-7585 & $44360 \pm 620$ & $43920 \pm 620$ & ams & $46834 \pm 1505$ \\
\hline Ozernay River 5 & SZ03-112(c) & Mollusc & & 57.3 & $>60$ & CURL-7586 & $42910 \pm 520$ & $42470 \pm 520$ & ams & $45363 \pm 931$ \\
\hline Ozernay R. delta 1 & SZ 02-07 & Mollusc & M-IV & 22.5 & ca 28 & CURL-6944 & $43230 \pm 330$ & $42790 \pm 330$ & $0.9 \%$ & $45627 \pm 941$ \\
\hline Ozernay R. delta 2 & SZ 02-15 & Mollusc & M-IV & 10 & ca 12 & CURL-6945 & $40330 \pm 360$ & $39890 \pm 360$ & $1.8 \%$ & $43558 \pm 502$ \\
\hline Ozernay R. delta 2 & SZ 02-18 & Mollusc & M-IV & 8 & ca 12 & CURL-6946 & $34760 \pm 180$ & $34320 \pm 180$ & $-1.2 \%$ & $40431 \pm 672$ \\
\hline Ozernay R. delta 3 & SZ 02-24 & Mollusc & M-IV & 33 & ca 35 & CURL-6947 & $37240 \pm 470$ & $36800 \pm 470$ & $1.4 \%$ & $42123 \pm 231$ \\
\hline
\end{tabular}

checked for additional species not present in the larger fraction; none were found. The foraminiferal specimens were generally well preserved. Except for a few single specimens of Neogloboquadrina pachyderma (sinistral), only benthic foraminifera were present. Analyses of sites Ozly and Ozlz by T. Dmitrieva at the "All Russian oil geology Institute," St. Petersburg, followed similar methods and have been standardized as much as possible with the Aarhus taxonomy (Table 2).

Geochronology-Four methods were employed: Accelerator Mass Spectrometer Radiocarbon (AMS ${ }^{14} \mathrm{C}$; mollusc, wood and whalebone), Electron Spin Resonance (ESR; mollusc), Green Stimulated Luminescence (GSL; sediment) and Amino Acid Geochronology of Aspartic
Acid (D/L Asp; mollusc). A total of 19 AMS ${ }^{14} \mathrm{C}$ ages were determined at two laboratories. One set of samples was prepared at the Laboratory for AMS Radiocarbon Preparation and Research at the University of Colorado, Boulder (CURL samples, Table 3), and measured at Wood Hole Oceanographic Institution and the University of California, Irvine. Concurrently measured blank ages were $54-56.9{ }^{14} \mathrm{C}$ ka BP. A second set of samples was prepared and measured at the Radiocarbon Dating Laboratory AMS, Department of Geology, Lund University, Sweden (LuS samples, Table 3). Concurrently measured blank ages were $47.1 \pm 0.57{ }^{14} \mathrm{C}$ ka BP. Pre-treatment of most mollusc shells at the Colorado laboratory included heavy leaching, with subsequent dating of the innermost $4-13 \%$ of the 
Table 4

Compilation of ${ }^{14} \mathrm{C}$ ages for mammoth remains on October Revolution Island, Severnaya Zemlya, Russia

\begin{tabular}{|c|c|c|c|c|c|c|c|}
\hline Sites mammoth remains & Sample type & Lat. ${ }^{\circ} \mathrm{N}$ & Long. ${ }^{\circ} \mathrm{E}$ & Comments & Lab no. & Conv. ${ }^{14} \mathrm{C}$ age & Cal ka BP \\
\hline E Vavilov Ice Cap ${ }^{a}$ & Mammoth tusk & 79.15 & 97.45 & & LuA-4820 & $10450 \pm 110$ & $12354 \pm 214$ \\
\hline SW Universitetskiy Ice Cap ${ }^{b}$ & Mammoth tusk & 78.82 & 97.67 & & LU-610 & $11500 \pm 60$ & $13403 \pm 121$ \\
\hline NW Albanova Ice Cap ${ }^{b}$ & Mammoth tusk & 79.9 & 94.58 & Outer part & LU-654A & $19640 \pm 330$ & $23424 \pm 503$ \\
\hline same as above & Mammoth tusk & & & Inner part & LU-654B & $19270 \pm 130$ & $23046 \pm 337$ \\
\hline NE Vavilov Ice Cap ${ }^{b}$ & Mammoth tooth & 79.47 & 96.75 & & LU-688 & $19970 \pm 110$ & $23875 \pm 247$ \\
\hline NE Vavilov Ice Cap ${ }^{b}$ & Mammoth tibia & 79.52 & 96.92 & Standard method & LU-749A & $24910 \pm 200$ & $29890 \pm 308$ \\
\hline same as above & Mammoth tibia & & & Purified collagen & LU-749C & $24960 \pm 210$ & $29920 \pm 314$ \\
\hline
\end{tabular}

${ }^{a}$ Unpublished data; personal communication J. Nilsson and C. Hjort, Lund university, Sweden.

${ }^{\mathrm{b}}$ Makeyev et al. (1979).

original shell mass. Two small shells could only be leached to $53 \%$ and $69 \%$ (CURL-6945, CURL-6946). Most of the Lund samples were leached to $\sim 70 \%$ of their original mass. Because ${ }^{14} \mathrm{C}$ age seems to increase with additional leaching in some samples, all mollusc ${ }^{14} \mathrm{C}$ ages should be considered as minimum estimates. The dating of a narwhal tusk followed pre-treatment to extract the ENV-cleaned aminoacid fraction (modified from Stafford et al., 1991). Wood pre-treatment employed standard Acid-Base-Acid washes. Mollusc and whalebone ages were reservoir-corrected by subtraction of 440 years from the laboratory-reported, $\delta^{13} \mathrm{C}$-corrected ages (Mangerud and Gulliksen, 1975; Olsson, 1980; Forman and Polyak, 1997). To assist a first-order comparison to other dating methods, corrected ages up to $50{ }^{14} \mathrm{C}$ ka were calibrated based on the University of Cologne Radiocarbon Calibration Program Package (CALPAL) using the CALPAL 2004 SFCP data set (CALPAC website). It allows calibration beyond the ca $26 \mathrm{ka}$ limit of INTCAL04, although the calibrated ages must be considered rough approximations (van der Plicht et al., 2004).

The 25 ESR ages (Table 5) on marine molluscs were performed at the Research Laboratory for Quaternary Geochronology at Tallinn Technical University, Estonia. Unexposed shell samples were retrieved from within cleaned sections, followed by sampling of sediments enclosing the dated shell for measurements on background dose rates. Standard analytical procedures were used (Molodkov, 1988; Molodkov et al., 1998).

All 25 GSL ages (Table 6) were determined at the Luminescence Dating Research Laboratory, University of Illinois at Chicago, USA. The multiple-aliquot regeneration (MAR) method (Singhvi et al., 1982; Jain et al., 2003) was used on the $100-200 \mu \mathrm{m}$ quartz fractions. All samples consisted of well-sorted fine to medium sand, composed of $>80 \%$ quartz. The quartz fraction was further isolated using the heavy liquid Na-polytungstate, and a 40-min immersion in HF was applied to etch the outer $10+$ microns of grains (Mejdahl and Christiansen, 1994). The purity of quartz separate was evaluated by petrographical inspection. Samples that showed $>1 \%$ of non-quartz minerals were re-treated with HF. Duplicate or triplicate reaction with HF was often needed. The purity of selected samples was further tested by exposing small aliquots to infrared excitation $(880 \mathrm{~nm})$, which preferentially excites feldspar minerals. The selected samples showed weak emissions ( $<300$ counts), indicating a spectrally pure quartz extract. Multiple aliquot regenerative (MAR) ages were determined using the component-specific dose normalization (Table 6), similar to Jain et al. (2003). An Automated Daybreak 1100 reader used green light excitation $(514 \hat{\mathrm{A}} \pm 20 \mathrm{~nm})$. Laboratory solar resetting of natural luminescence was by an 8-h exposure to a $275 \mathrm{~W}$ GE Mercury Vapor Sunlamp (Richardson, 1994). A normalization dose $\left(\sim 82 \mathrm{~Gy} \hat{\mathrm{I}}^{2}\right)$ was applied to all discs prior to analysis. A pre-heat of $150 \hat{\mathrm{A}}^{\circ} \mathrm{C}$ for $1 \mathrm{~h}$ yielded a luminescence distribution most similar to the natural emissions. To determine dose rate, the $\mathrm{U}$ and $\mathrm{Th}$ content were measured by inductively coupled plasma-mass spectrometry (ICP-MS) or by alpha counting. The radioactive potassium component $(40 \mathrm{~K})$ is determined from the assayed $\mathrm{K}_{2} \mathrm{O}$ content of the sediment by ICP-MS. The beta and gamma dose was adjusted according to grain diameter (Fain et al., 1999). The estimated dose rate includes a small cosmic ray component between 0.15 and $0.20 \mathrm{~Gy} / \mathrm{ka}$ dependent on depth of sediment (Prescott and Hutton, 1994). A moisture content of $20-30 \%$ is assumed, which is water saturated values, consistent with the presence of permafrost (Table 6).

More than 130 separate $\mathrm{D} / \mathrm{L}$ Asp (Aspartic Acid) analyses were measured on marine mollusc shell samples using a Reverse-Phase Liquid Chromatograph (RPLC) at the Amino Acid Geochronology Laboratory at Northern Arizona University. Sample preparation follows that of Kaufman and Manley (1998). Simultaneous measurement of $\mathrm{D} / \mathrm{L}$ Glutamic and $\mathrm{D} / \mathrm{L}$ Serine helped recognize and exclude a few aberrant samples. A single $\mathrm{D} / \mathrm{L}$ Asp ratio was calculated for each stratigraphic horizon at each site by averaging the results from 4 to 8 shells. No systematic differences in $\mathrm{D} / \mathrm{L}$ Asp ratio were observed between mollusc taxa: Hiatella arctica, Mya truncata, Macoma ssp., Portlandia ssp. and Astarte ssp. The D/L Asp results provide a relative dating tool to help correlate stratigraphic horizons between field sites (Table 7). 


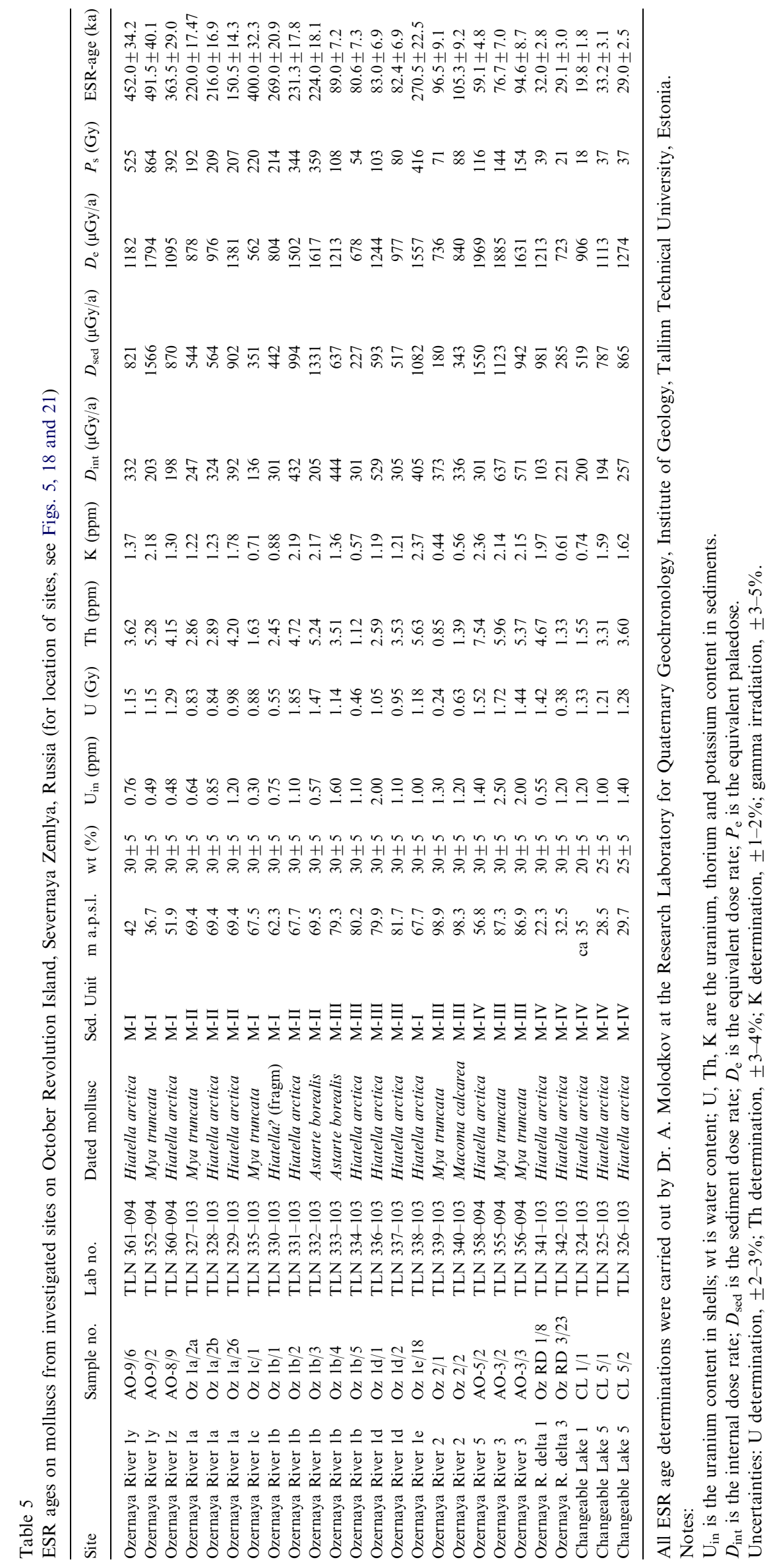




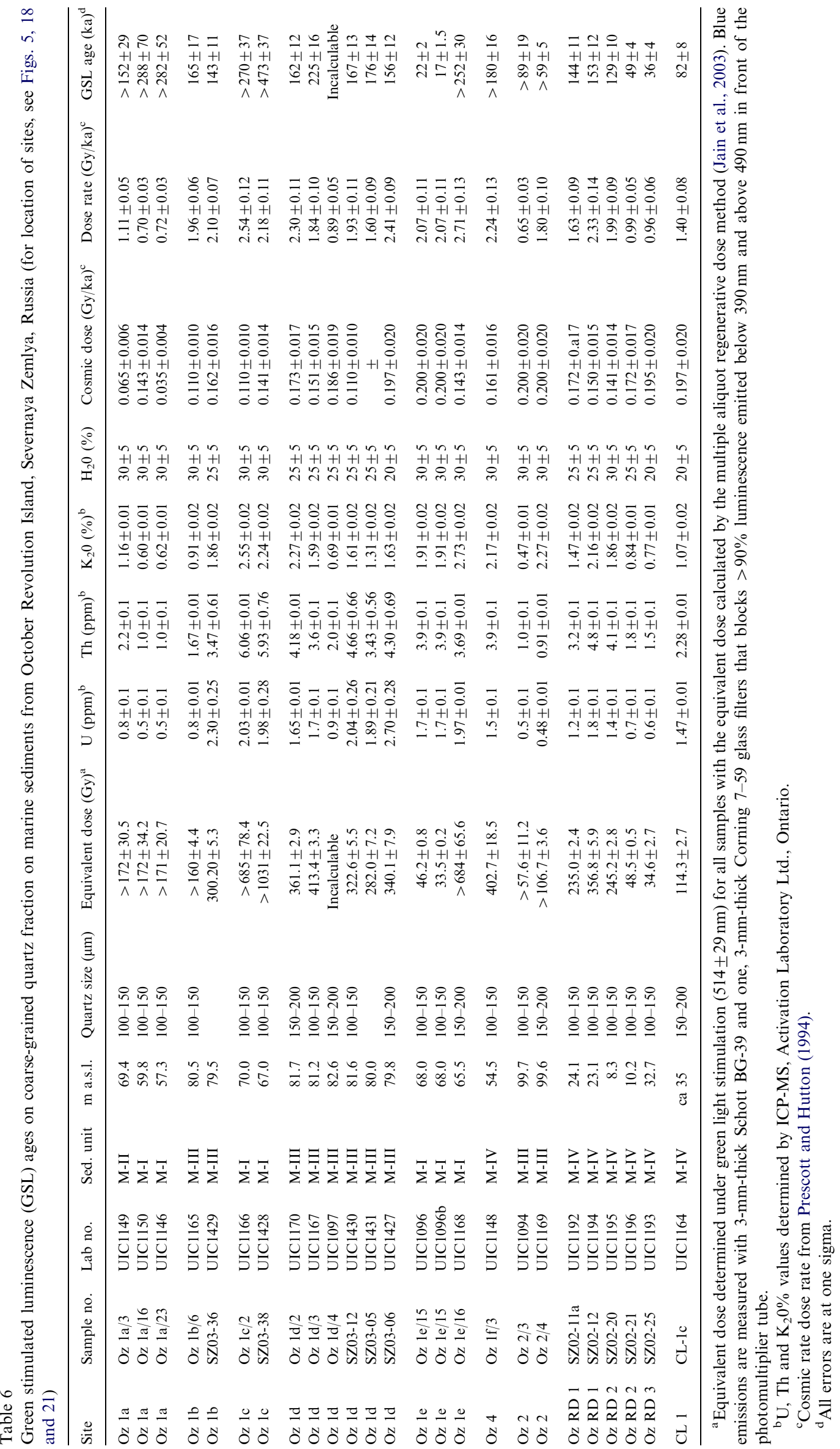


Table 7

$\mathrm{D} / \mathrm{L}$ Asp amino acid results by site and marine lithologic unit on October Revolution Island

\begin{tabular}{lllrl}
\hline Site & Unit & D/L Asp & Count & Ave altitude \\
\hline High shorelines & M-III & $0.188 \pm 0.003$ & 4 & 120.2 \\
Oz-2 & M-III & $0.192 \pm 0.015$ & 17 & 100.0 \\
Oz-3 & M-III & $0.185 \pm 0.019$ & 4 & 87.2 \\
Oz-1d & M-III & $0.201 \pm 0.015$ & 10 & 81.0 \\
Oz-1b & M-III (upper) & $0.209 \pm 0.020$ & 7 & 79.7 \\
Oz-1b & M-III (lower) & $0.262 \pm 0.015$ & 3 & 75.7 \\
Oz-1a & M-II & $0.227 \pm 0.016$ & 6 & 69.4 \\
Oz-1b & M-II & $0.267 \pm 0.023$ & 8 & 68.6 \\
Oz-1c & M-II (outlier?) & $0.226 \pm 0.013$ & 7 & 68.4 \\
Oz-1e & M-I & $0.283 \pm 0.005$ & 6 & 65.0 \\
Oz-1b & M-I & $0.281 \pm 0.007$ & 5 & 62.0 \\
Oz-5 & M-IV & $0.125 \pm 0.010$ & 4 & 60.0 \\
Oz-1a & M-I & $0.296 \pm 0.007$ & 3 & 58.3 \\
Oz-1z & M-I & $0.261 \pm 0.009$ & 5 & 51.2 \\
Oz-1y & M-I & $0.300 \pm 0.035$ & 2 & 42.8 \\
Oz-1y & M-I (outlier?) & $0.212 \pm 0.011$ & 4 & 42.8 \\
D-3 & M-IV & $0.132 \pm 0.016$ & 11 & 31.1 \\
CL-5 & M-IV & $0.143 \pm 0.009$ & 3 & 28.9 \\
D-1 & M-IV & $0.092 \pm 0.015$ & 7 & 22.2 \\
D-2 & M-IV & $0.112 \pm 0.014$ & 6 & 8.5 \\
\hline
\end{tabular}

${ }^{\mathrm{a}} \mathrm{D} / \mathrm{L}$ Asp ratio differs between the upper and lower portions of the MIII unit at this site.

${ }^{b} \mathrm{D} / \mathrm{L}$ Asp ratio is lower at this site than for the M-I unit at other sites.

${ }^{c} \mathrm{D} / \mathrm{L}$ Asp ratio is lower than other samples within the same unit at this site.

\section{Geomorphic and lithostratigraphic overview}

\subsection{Raised marine landforms}

Geomorphic signatures of higher-than-present sea levels are common in satellite and aerial images of October Revolution and Bolshevik Islands, particularly escarpments, beaches and terraces. Such features were previously observed in the field (Bolshiyanov and Makeyev, 1995) but never mapped until our study. The raised marine landforms are best expressed where the former coastline is perpendicular to the strike of gently dipping bedrock. Field observations on southern October Revolution Islandwhere raised marine landforms are abundant - confirms the image-based interpretations (Fig. 4). Abundant marine landforms were also observed on satellite-based images of northwestern and southwestern Bolshevik Island.

Elevations of the raised marine landforms on S October Revolution Island and NW and SW Bolshevik Island range from approximately 12 to $150 \mathrm{~m}$ a.s.l. (Fig. 4). The landform elevations were first approximated with 1:500 000 topographic maps (25-50 m contour interval, plus spot elevations). Improved estimates for portions of south central and southwestern October Revolution Island were made with 1:100 000 maps (10 m contour interval, plus spot elevations). Even more refined values were assembled for sample sites on southern October Revolution Island, where elevations of shorelines and terraces were directly measured.
The highest confirmed marine landforms outline a shoreline at $\sim 140$ ma.s.l. in the study area on southern October Revolution Island (Fig. 4). Large areas above this height were searched on foot to test for the absence of higher landforms evident on images. Indeed, no such landforms were found. Potentially higher marine landforms exist on Bolshevik Island as suggested by multiple escarpments with bases at $\sim 150 \mathrm{~m}$ a.s.l., which is an estimate $( \pm 10-20 \mathrm{~m})$ derived from 1:500 000 topographic maps. The most prominent raised marine feature identified on images and confirmed in the field is a shoreline at $\sim 35$ m a.s.l. on southern October Revolution Island, which extends $\sim 70 \mathrm{~km}$ between the Vavilov and University ice caps (Fig. 4). The lowest confirmed marine landform is a single terrace at $12 \mathrm{~m}$ a.s.l. near the mouth of the Ozernaya River. The present shoreline is characterized by abundant spits and barrier islands.

\subsection{Quaternary sediment sections}

Prior geologic studies on all three of the main islands of Severnaya Zemlya show that Quaternary sediment sections are mostly restricted to river valleys and other topographic depressions (Bolshiyanov and Makeyev, 1995). Most of these sediments are of marine origin, but also sediments of glacial and glaciofluvial origins occur. A few of the largest sediment sections can be seen on satellite and aerial images (Figs. 3, 5, 18 and 20). Sediments in higher areas are often limited to a thin mantle over bedrock.

The Quaternary deposits on southern October Revolution Island thinly blanket the Palaeozoic sedimentary bedrock. This is evident along much of the Ozernaya River, the main southdirected meltwater river from the Vavilov and Karpinskiy ice caps, which has cut a wide and up to $50-70 \mathrm{~m}$ deep channel into the surrounding lowlands. The river channel is mostly flanked by sedimentary rocks but occasionally thick Quaternary sediment successions are revealed laterally bounded by rising bedrock surfaces, representing palaeo-valley fills. One such locality is the $\mathrm{Oz} 1$ site situated on the western bank of the Ozernaya River (Fig. 5). This site provides critical context for the Quaternary stratigraphy of October Revolution Island, similar to previous efforts by Bolshiyanov and Makeyev (1995; site 29). Our investigations confirm their principal stratigraphic framework, refine the stratigraphy, and provide additional insights on the chronological and environmental history.

The stratigraphy from the Ozernaya 1 site is supplemented by a number of sites, some nearby (Oz 2-5; Fig. 5) and others tens of kilometres away, located near the river mouth of the Ozernaya River (the Ozernaya River Delta localities, Fig. 21) and in the Changeable Lake area (Fig. 18). Some of these sites reveal sediment successions that are correlated to the units identified within the $\mathrm{Oz} 1$ site, but others are stratigraphically younger than the $\mathrm{Oz} 1$ units and too distant for physical correlation. An age envelope for each identified sediment unit was calculated based on using ESR ages as minimum estimates and GSL ages as close, but possibly overestimates (see discussion in Section 6 below). 


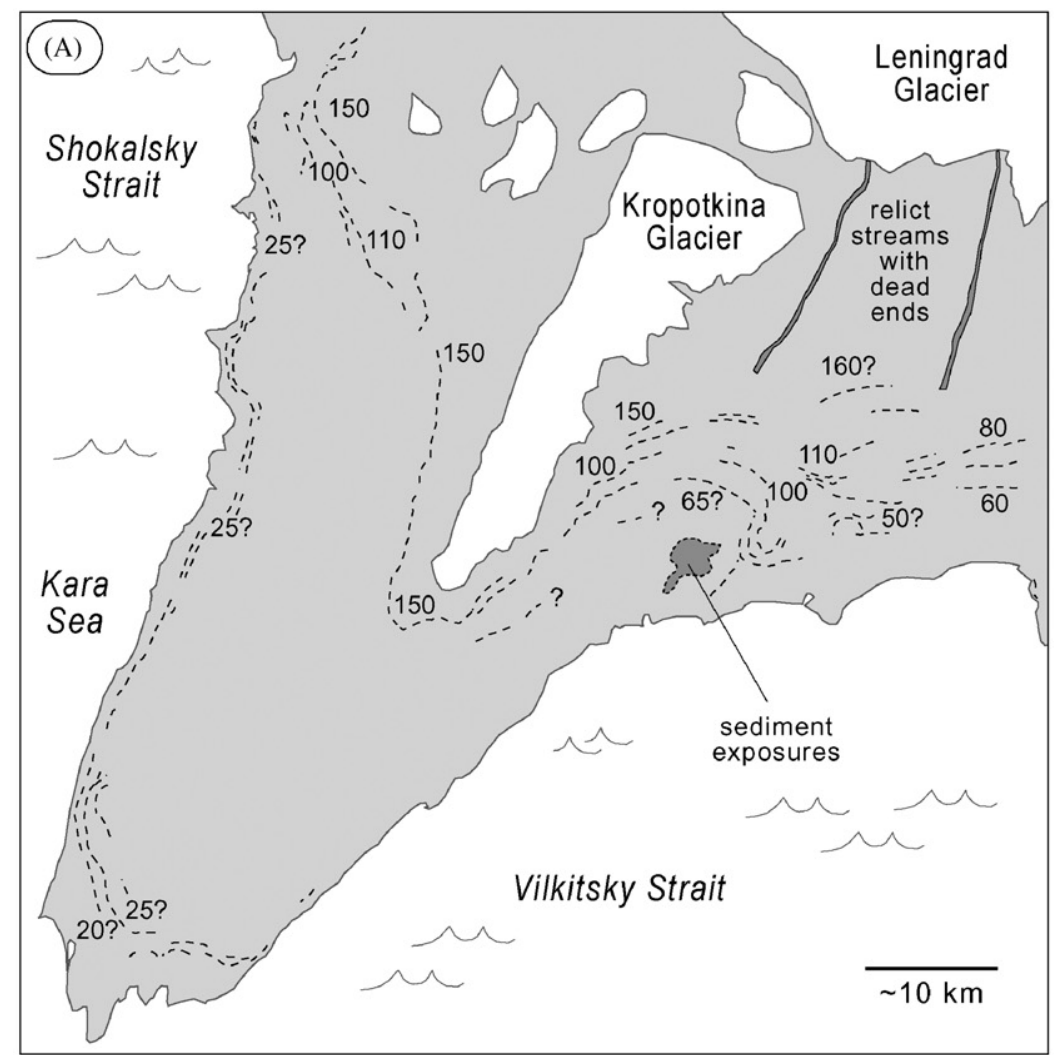

\section{SW Bolshevik Island}

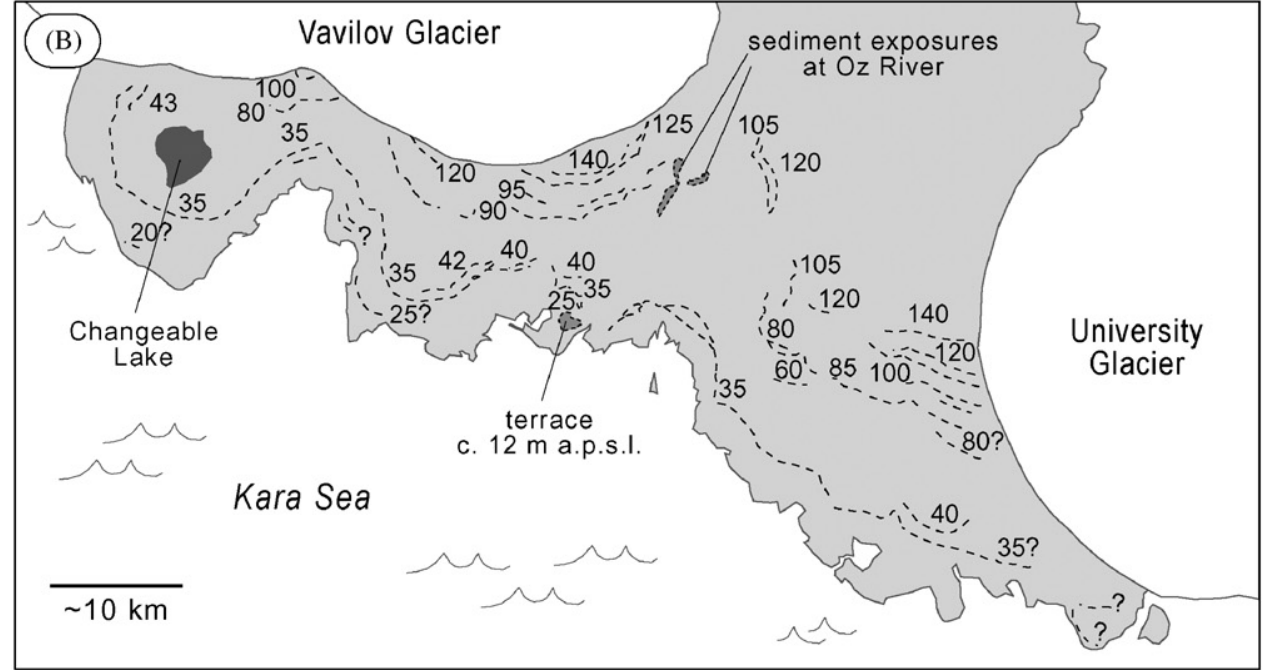

S. October Revolution Island

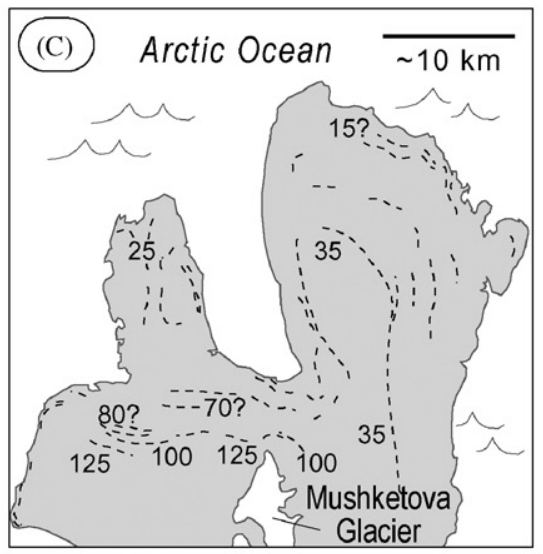

NW Bolshevik Island
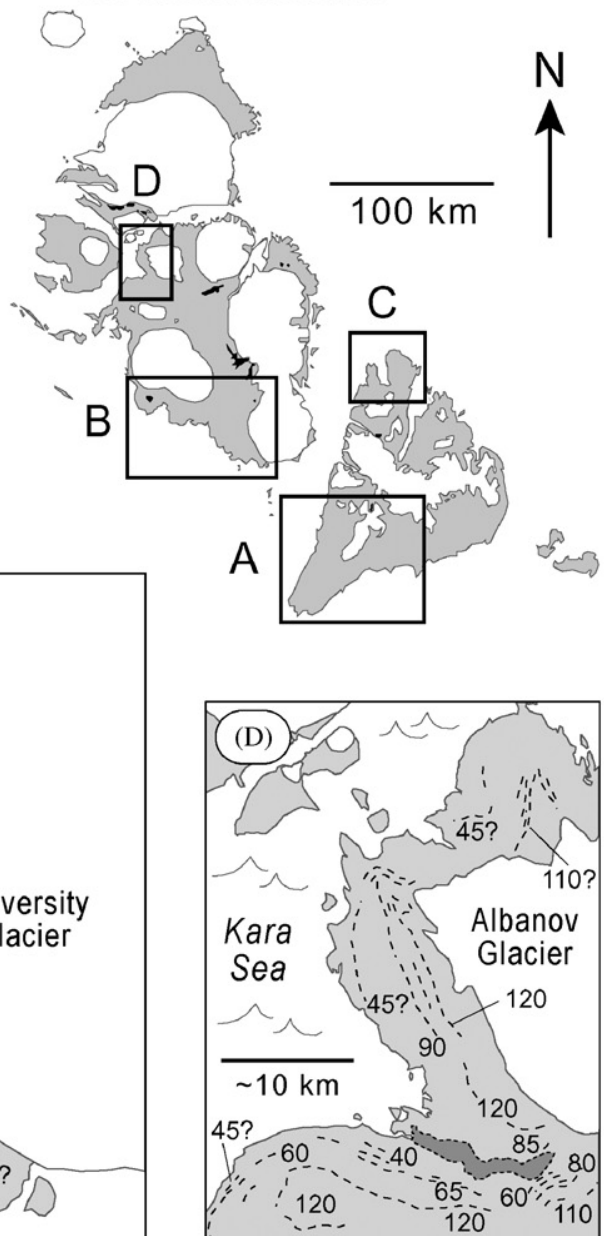

NW October Revolution Island

Fig. 4. Raised beaches on October Revolution and Bolshevik Islands, as interpreted from Corona satellite images, aerial photographs, and in the case of southwestern October Revolution Island, from field studies.

\section{Study sites}

\subsection{Ozernaya River, site $1(\mathrm{Oz} 1)$}

The Quaternary strata are exposed for $>1 \mathrm{~km}$ along the Ozernaya River at site 1. Slumping and fluvial erosion have left a series of erosional-remnant ridges (Fig. 6A) leading up to a flat sediment surface at $80-85$ ma.s.l. Identified sediment horizons could be correlated visually from ridge to ridge and in the erosional back-walls beneath the top surface forming a sediment succession $\sim 50 \mathrm{~m}$ thick and comprising three marine units (Marine units I-III) divided by four glacial till units (Till units I-IV), all erosively cut and stratigraphically overlain by a fluvial gravel unit (left side in Fig. $6 \mathrm{~A}^{1}$ ). The sedimentary units were mapped and logged at seven different subsites, marked y, z, a, b, c, d 


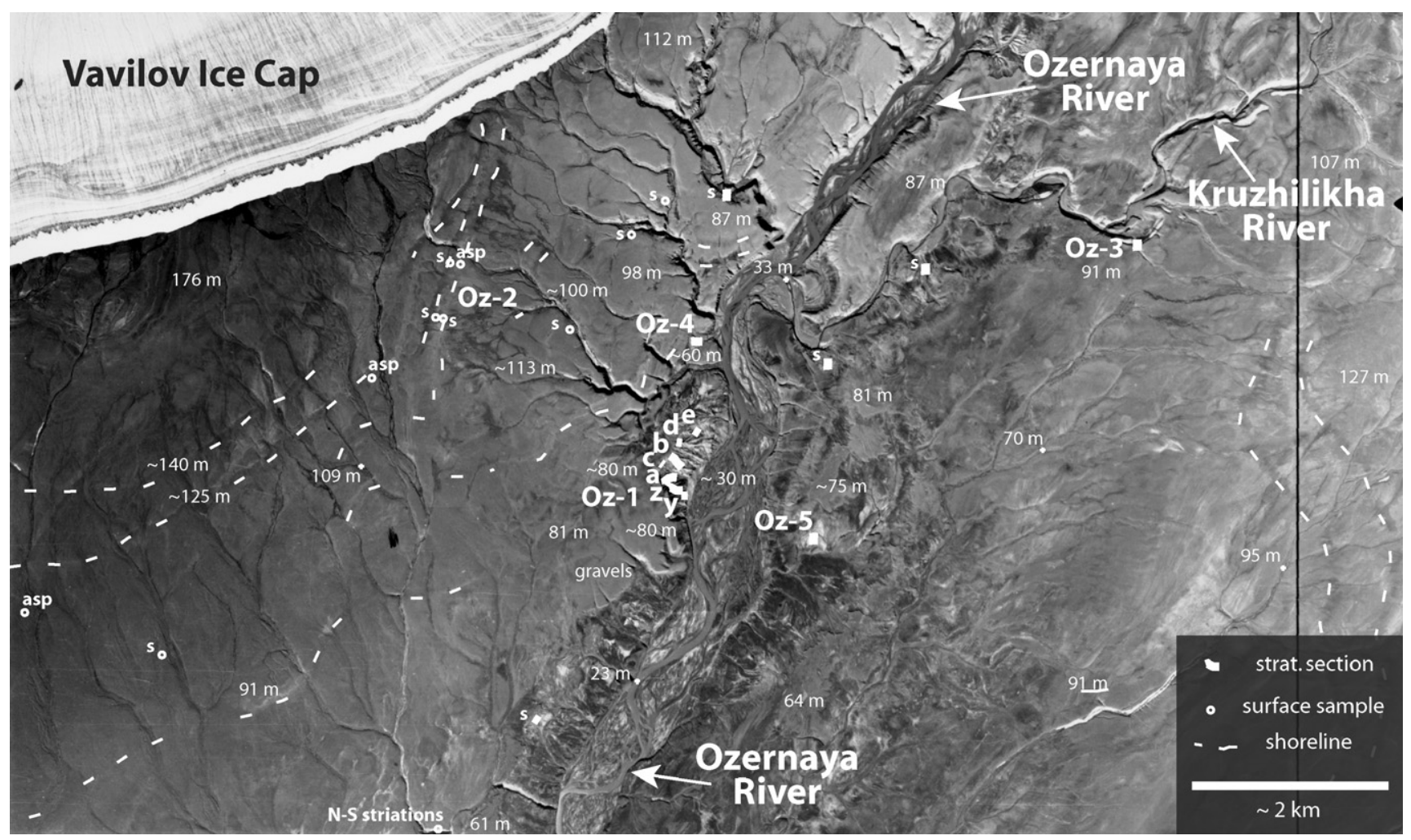

Fig. 5. Aerial photograph of the upper part of the Ozernaya river valley, showing raised beach features, sampling localities and studied stratigraphic sections. Circles marked "asp" show sites where collections of molluscs from the surface were analysed for aspartic-acid geochronology. Circles marked 's' are similar sites, but not analysed.

and e from south to north over a distance of ca $750 \mathrm{~m}$ (Figs. 5 and $6 \mathrm{~A}^{1}-\mathrm{A}^{2}$ ), the stratigraphy summarized in Fig. 7 and with detailed logs in Fig. 8.

Till unit I; description-T-I is a matrix-supported, massive and clast-rich clayey silty diamicton, only encountered in the lowermost part of section Oz-1y, here being $+1.7 \mathrm{~m}$ thick, poorly exposed and the base obscured by thick slump deposits with permafrost. T-I is probably no more than a few metres thick based on a reconnaissance of deposits a few $100 \mathrm{~s}$ m south of Oz-1y. This reconnaissance also indicated an underlying marine sediment (Marine unit 0), but this was not further investigated because of their discovery at the very end of our field work.
Till unit I; interpretation - The diamicton is tentatively interpreted as a subglacially deposited till. In absence of structural data, the source area and ice-flow direction during deposition is unknown.

Marine unit I; description - M-I sediments at sites Oz-1y, $-1 \mathrm{z}$ and $-1 \mathrm{a}$ (Fig. 8) are coarsening upward and bed geometry changes with rising altitude. The original minimum thickness of the unit is at least $35 \mathrm{~m}$ (35-70 $\mathrm{m}$ a.s.1.), and possibly more as there is an erosive contact to the overlying T-II. The succession starts with thick massive clay beds, interbedded with $1-5 \mathrm{~cm}$ thick beds of fine sand and occasional fine gravel stringers (Oz-1y). The strata dip $2-6^{\circ}$ towards the north-northeast.

Fig. 6. (A) Overview of the Ozernaya River site $1\left(\mathrm{~A}^{1}\right.$, southern part; $\mathrm{A}^{2}$ northern part; view direction towards NE). The dissected sediments constitute a palaeo-valley fill, $\sim 50 \mathrm{~m}$ thick and forming a plateau at $80 \mathrm{~m}$ a.s.l. Position of logged sections (see Fig. 5) are indicated by letters $\mathrm{y}, \mathrm{z}$ and a-e. The Vavilov Ice Cap is seen in the background; its margin is situated $4 \mathrm{~km}$ from the river bed. (B) M-I sediments, site Oz-1a; low-angle foresets of interbedded fine sand and silt, occasionally with large out-runner clasts. (C) M-I sediments, site Oz-1a; interbedded sand and silt, the silt beds drawn down into the sand beds due to bioturbation (white arrows) and thus yield diffuse bed contacts. (D) M-I sediments, site Oz 1e; massive, interbedded coarse and fine silt beds with thin sand beds in upper part. (E) M-I sediments, site Oz-1e; wood in massive silt beds. Wood fragments and seaweed mats are concentrated to specific horizons in the sediment sequence. (F) M-I sediments and T-II, site Oz-1a; synclinal folding and extensional faulting of laminated marine sediments beneath contact to overlying till. Plotted fold limbs and faults indicate deformational stress from the north. (G) Detail of fold in (F). (H) M-I sediments and T-II, site Oz-1b; drag fold in marine sediments beneath contact to overlying till. Plotted fold limbs and faults indicate deformational stress from NNW. (I) M-II sediments, site Oz-1b; massive silty clay with floating drop-clasts. (J) M-II sediments, site Oz-1a; Serripes groenlandicus in massive M-II silt. (K) T- III, site Oz-1b; stratified diamicton (reddish band at arrows) due to smeared-out of weaker clast lithologies. (L) M-II sediments and T-III, site Oz-1b; marine silty clay with thin fine sand intrabeds. Note the sharp till boundary with undeformed marine sediments below. (M) M-III sediments and TIV, site Oz-1d; sheared contact (shear zone) between till and underlying marine sand is demarcated. (N) T-IV, site Oz-1d; striated clast in the contact to underlying M-III sand. (O) M-III sediments, site Oz-1d; massive silty clay with sand bed, carrying floating pebble- to cobble-sized clasts and frequent occurrence of shell fragments. (P) M-III sediments, site Oz-1d; stratified gravelly sand with frequent occurrences of in situ molluscs. Note burrow trace at white arrow. 

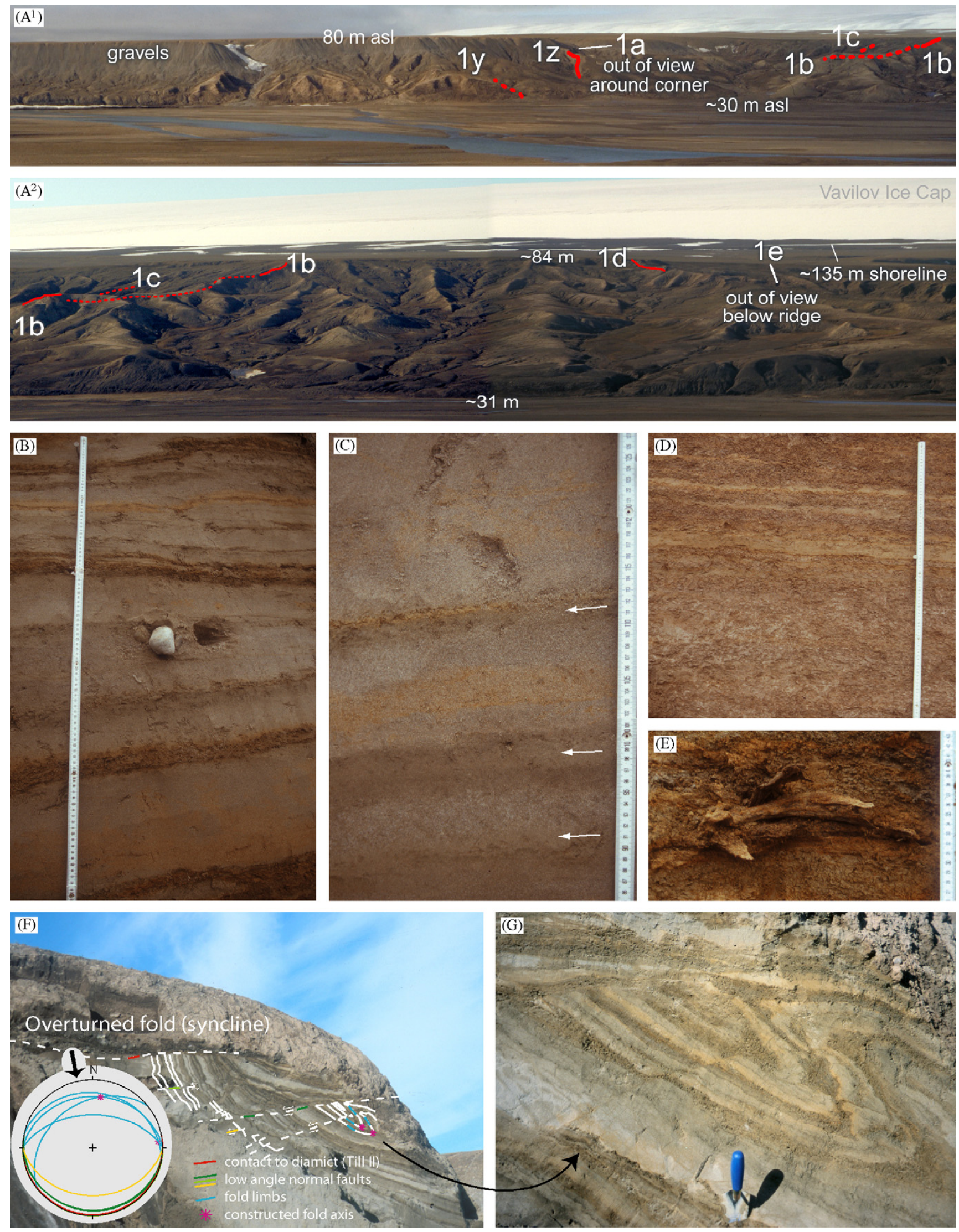

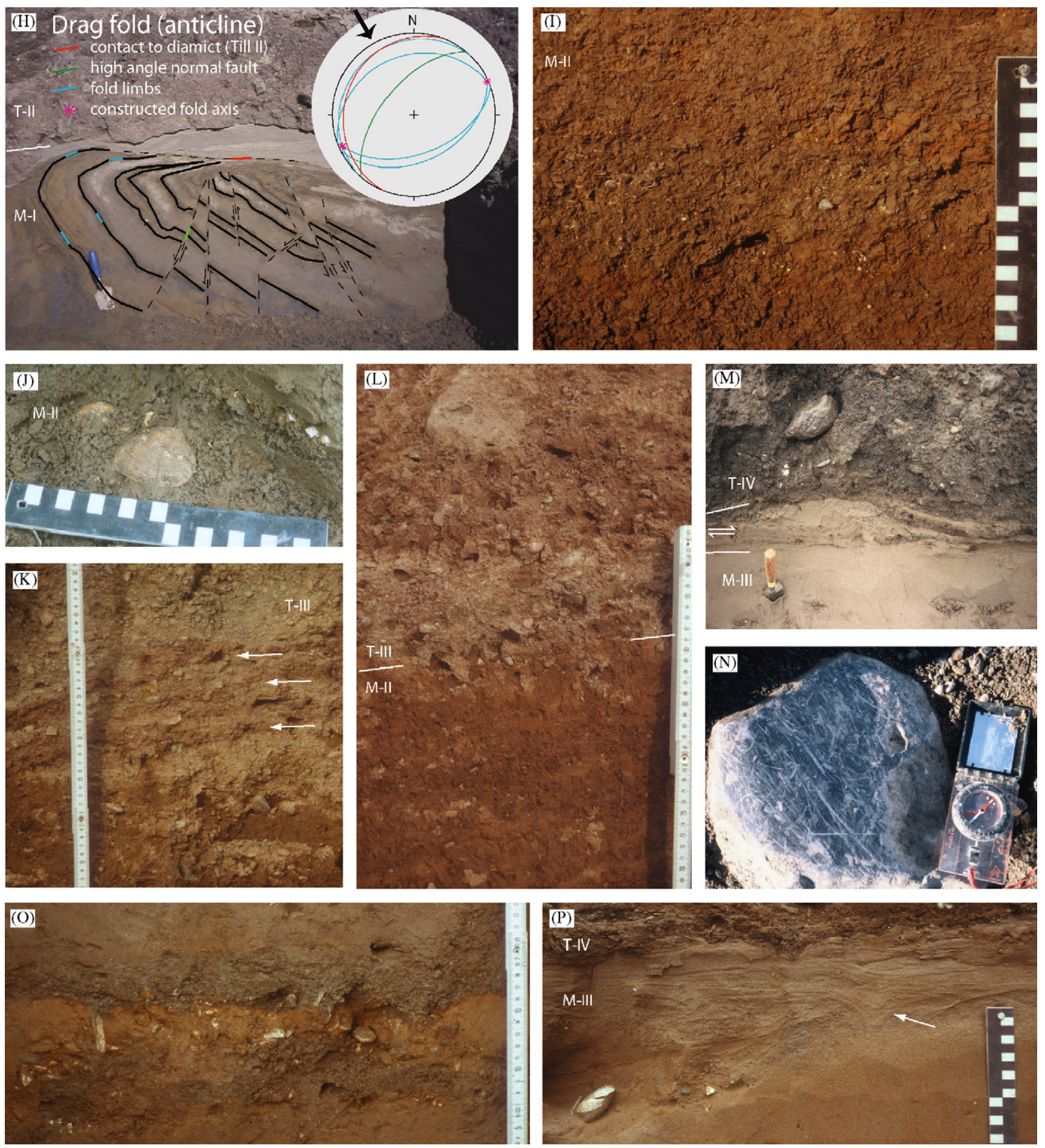

Fig. 6. (Continued)

Rare single floating clasts $(1-5 \mathrm{~cm})$ are randomly dispersed in the clay beds and bivalves occur both as shell fragments and as single and paired shells (Hiatella arctica and Portlandia arctica). Upwards (Oz-1z) massive to weakly laminated clayey silt is interbedded with increasing frequency and thickness of predominantly massive beds of fine sand. Minor facies constituents are vaguely planar parallel-laminated sand and some 3-7-cm thick beds of gravelly sand with erosional lower boundaries. Bed dip is $\sim 6^{\circ}$ towards SW, rising to a mean bed dip of $9^{\circ}$ above $60 \mathrm{~m}$ a.s.l., with dip directions toward the NNE. Molluse shells are frequent in the lower part of the section, but become rare above $\sim 53 \mathrm{~m}$ a.s.l. The M-I sediments displays the most diverse facies combinations at site Oz-1a, the succession showing a general bed dip of $15^{\circ}$ towards NNE-NE. Predominating facies are massive to weakly planar parallel-laminated beds of fine-to-medium sand, interbedded with thin beds (usually $0.5-4 \mathrm{~cm}$ ) of massive 


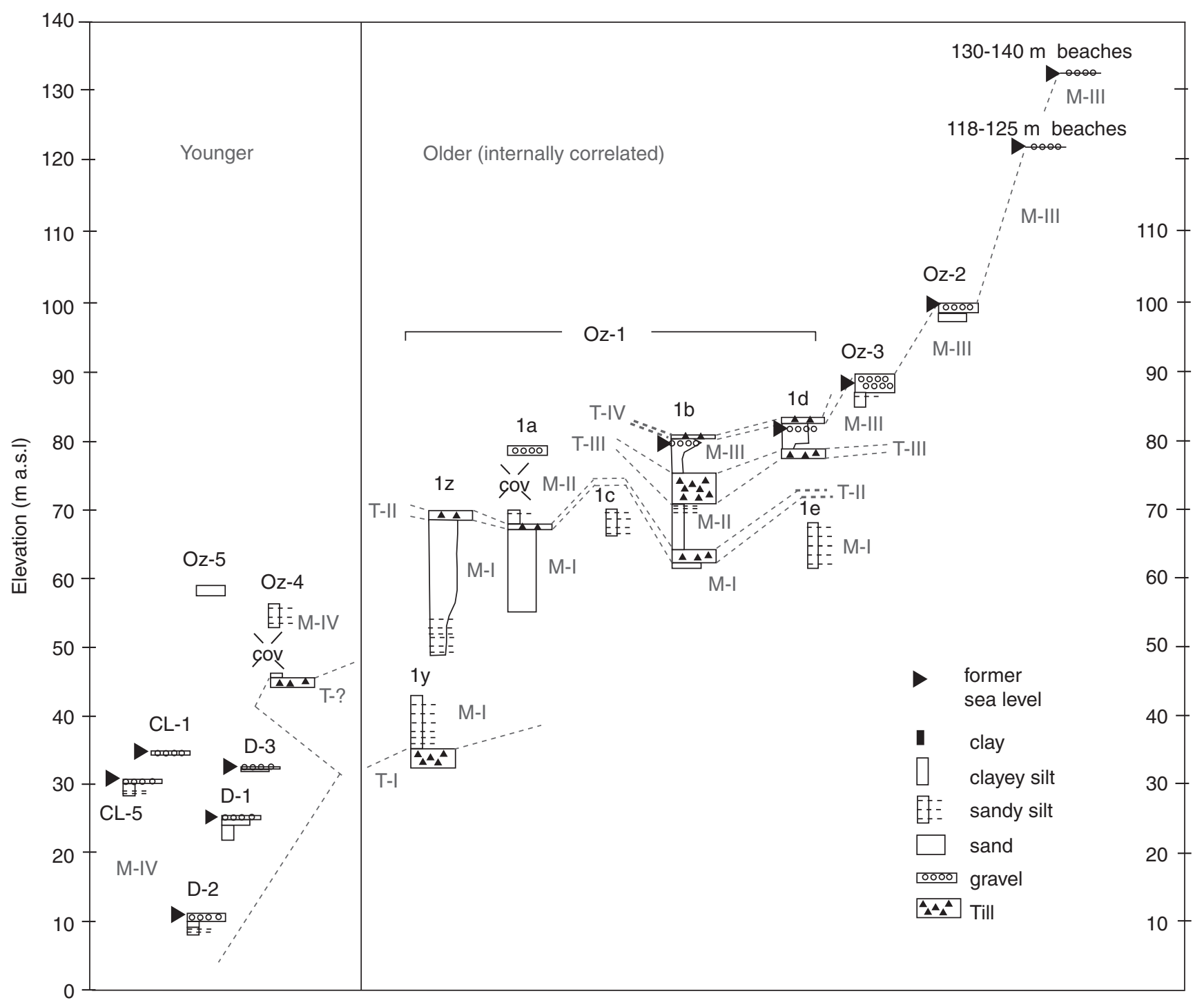

Fig. 7. Simplified stratigraphy and correlation chart for October Revolution Island.

silt. Occasionally the silt beds are $4-10 \mathrm{~cm}$ thick and then often internally laminated. The most common bed thickness for sand beds is $5-15 \mathrm{~cm}$, though bed thicknesses up to $90 \mathrm{~cm}$ occur. Many of the sand beds show a normal grading from medium sand at the base to fine sand at the top and a few beds carry single or agglomerated out-sized clasts $(2-7 \mathrm{~cm}$; Fig. 6B). Minor facies constituents are ripplelaminated fine sand, sometimes just occurring as thin form sets, and usually lying in successions from normally graded sand to ripple-laminated sand to silt draping. A few sand beds also reveal an inverse to normal grading. Many sand beds show increasing silt contents in their upper $2-5 \mathrm{~cm}$, starting diffusely from the clean yellow sand and becoming more silty and greyish towards the top (Fig. 6C) with no silt interbed to the next sand bed. On horizontal surfaces such top layers occur as subcircular to elongated pods of silt and sand, and are clearly the result of bioturbation with a previously deposited silt bed dragged down into the sand during burrowing activity. However, just a few gastropods and bivalves were encountered but the marine provenance was further supported by finds of fossil seaweed and a number of whalebones that have eroded out of the unit.

The foraminiferal faunas of Oz-1y, -z and -1a (Fig. 11) are dominated by Cassidulina reniforme, while assessory species include Elphidium excavatum forma clavata, Elphidium hallandense, Islandiella norcrossi and Haynesina orbiculare. Islandiella islandica is most commonly found in Oz-1y. Elphidium asklundi and miliolina are also present, particularly in Oz-1y and Oz-1z.

The sediment successions at sites $\mathrm{Oz}-1 \mathrm{c}$ and $-1 \mathrm{e}$ have facies compositions that differ considerably from those described above. At Oz-1c there is a stacked sequence of subhorizontally interbedded massive silty clay, clayey silt and thin beds of fine sand $(2-7 \mathrm{~cm})$, all with a lowfrequency occurrence of single floating clasts $(1-3 \mathrm{~cm}$, largest clast $25 \mathrm{~cm}$ ). In situ-positioned bivalves are frequent throughout the sequence, but were difficult to recover in identifiable pieces. Seaweeds occur in distinct horizons and 


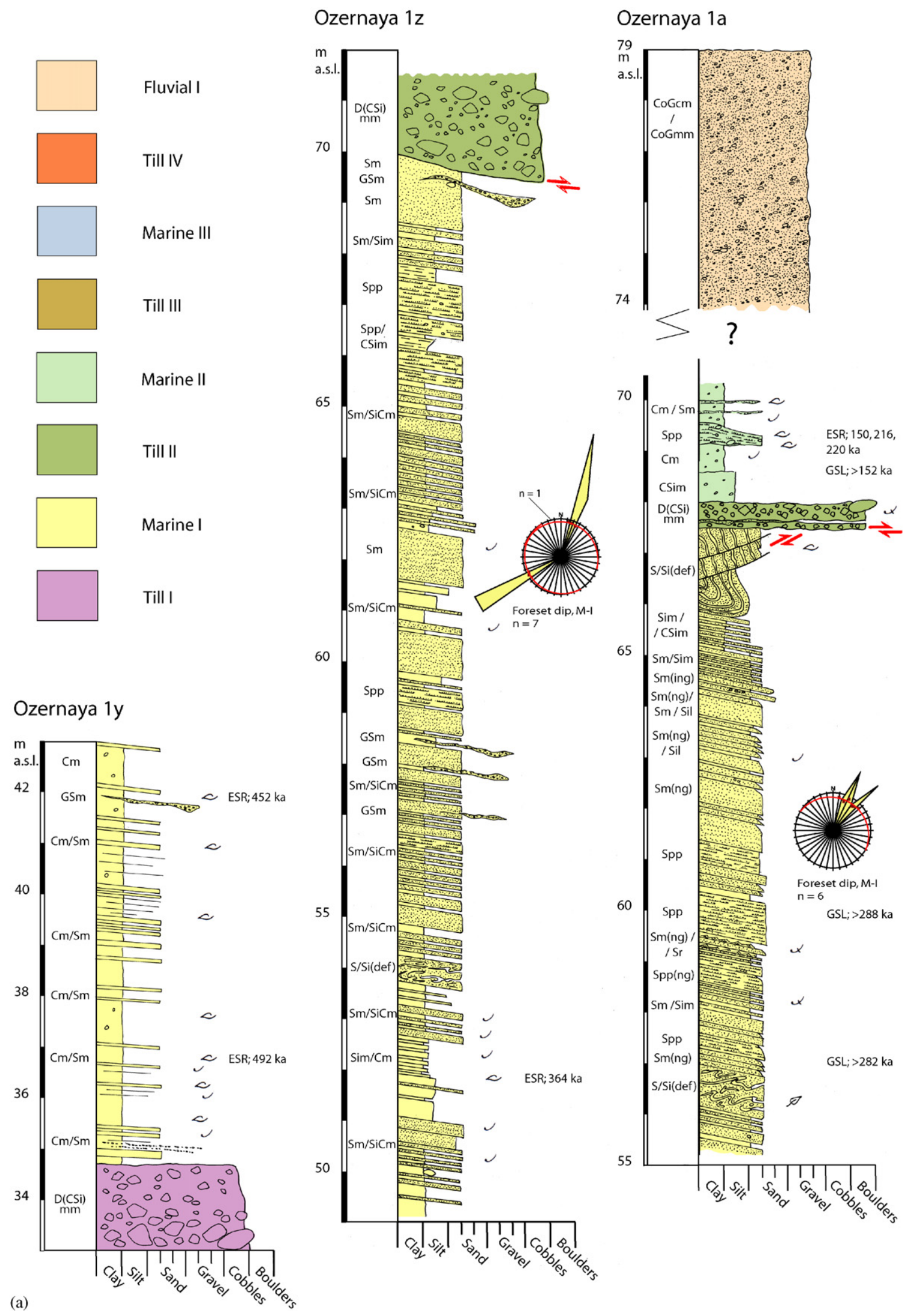

Fig. 8. Stratigraphic logs for the Ozernaya River site 1 (Oz 1) subsites (Fig. 5 for location). 


\section{Ozernaya $1 \mathrm{~b}$}

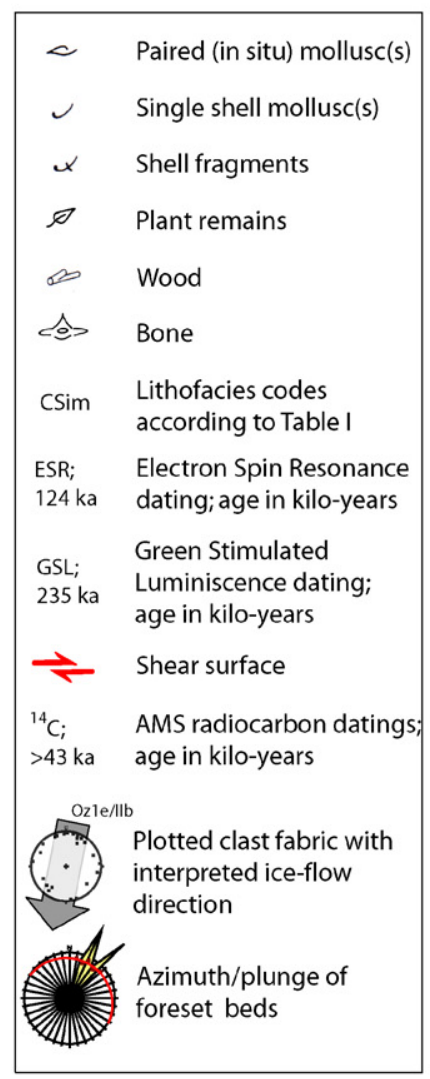

\section{Ozernaya 1c}

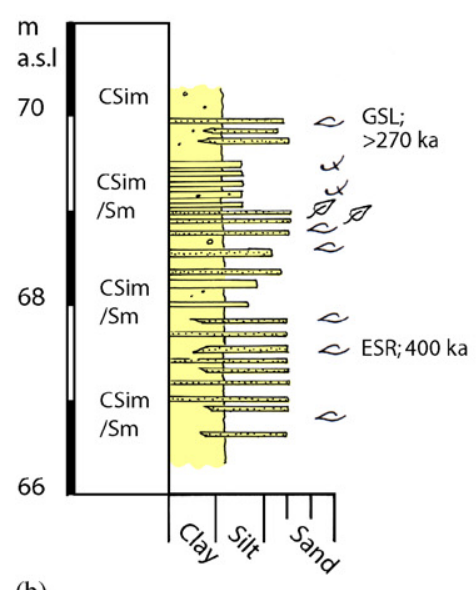

(b)
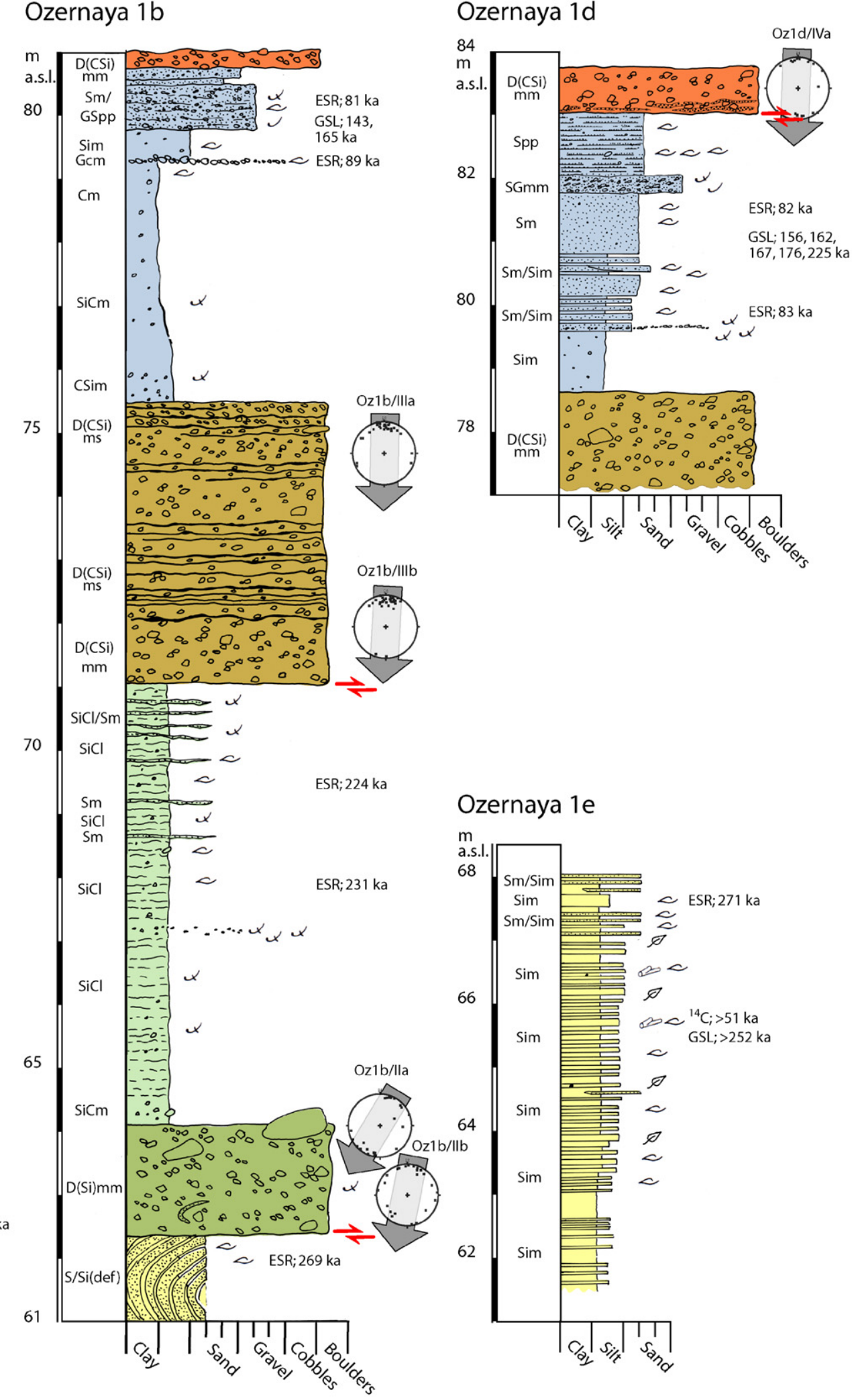

Ozernaya 1e

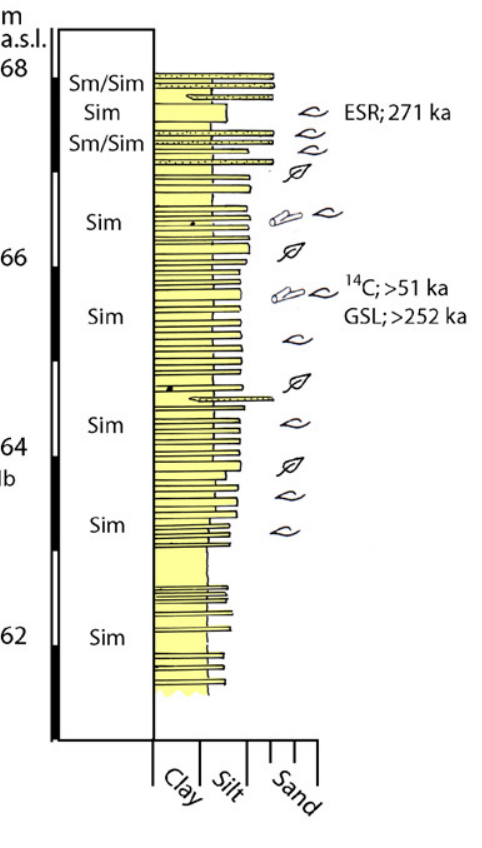

Fig. 8. (Continued)

wood fragments were observed at the base of the section but not found in situ. Site Oz-1e resembles site -1c in its top-most part but downwards the sand beds are lacking and instead there are interbedded fine and coarse silt beds
(Fig. 6D). Wood (Fig. 6E) and seaweed occur frequently in distinct horizons, the latter usually on bed contacts. The largest wood fragments observed in the section were twigs, $2-5 \mathrm{~cm}$ in diameter and $20-30 \mathrm{~cm}$ long. Logs, up to $20 \mathrm{~cm}$ in 


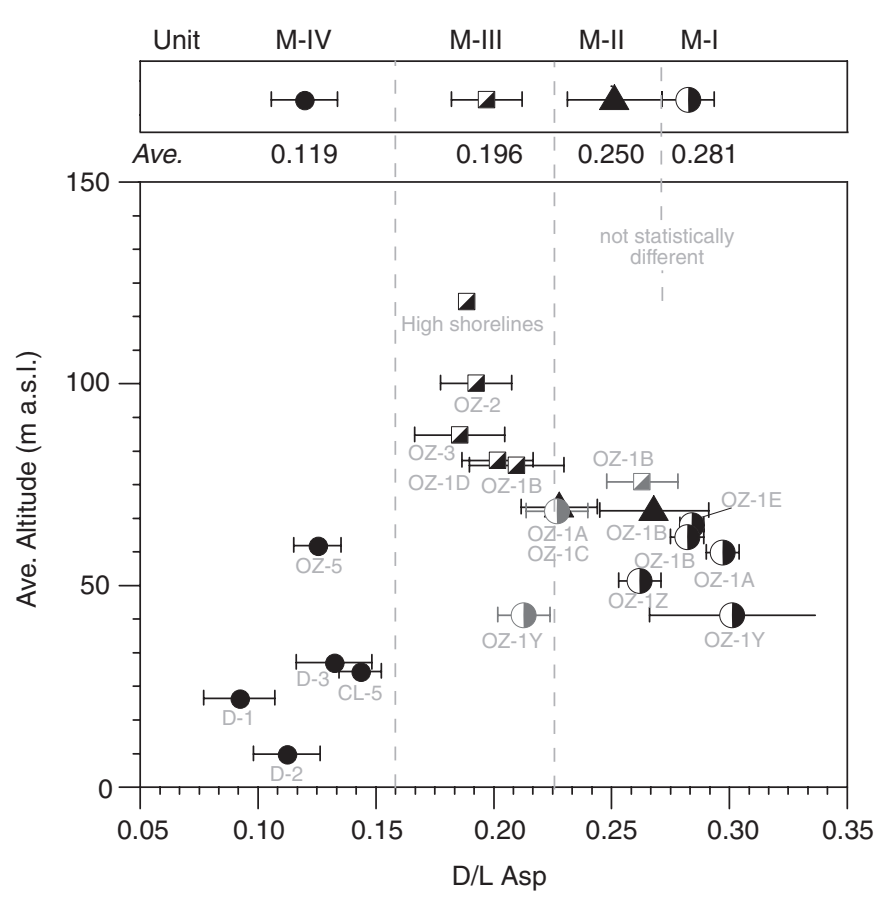

Fig. 9. Average $\mathrm{D} / \mathrm{L}$ Asp amino acid results by marine stratigraphic unit for investigated sites on October Revolution Island, plotted against the average altitude for the marine unit at that site.

cross section, some with preserved roots, are numerous on the surrounding ground surface. The mollusc fauna sampled beneath the exposure shows frequent occurrence of Astarte warhami, Mya truncata and Hiatella arctica, but Astarte elliptica and Macoma calcarea occur more sparsely.

The foraminiferal assemblages (Fig. 11, Oz-1c and -1e) are dominated by Cassidulina reniforme, with Elphidium albiumbilicatum and Elphidium excavatum f. clavata as assessory species. Other specimens belong to Astrononion gallowayi, Buccella spp., Islandiella norcrossi and Haynesina orbiculare. Epistominella spp., Islandiella norcrossi and Elphidium ustulatum decrease upwards, while Haynesina nivea increases.

Chronology-A wood sample yielded a ${ }^{14} \mathrm{C}$ age of $>50$ calka (Table 3 ). The average $\mathrm{D} / \mathrm{L}$ Asp ratio is $0.28 \pm 0.01(n=18$; Table 7; Fig. 9). Six ESR ages form two groups, one between 269 and $363 \mathrm{ka}$ and the other between 400 and $492 \mathrm{ka} \mathrm{BP}$ (Table 5). Four GSL samples provide support of the ESR ages as they suggest an age $>252-288 \mathrm{ka}$ BP (Table 6), with one additional outlier of $>473 \mathrm{ka}$ BP. One GSL sample was dated twice, due to the surprisingly young age received (sample Oz-1e, Table 6), ca 22 and $17 \mathrm{kaBP}$, respectively. We regard these results as erroneous indicators of the M-I depositional age because the GSL ages are considerably younger than corresponding ESR and ${ }^{14} \mathrm{C}$ ages (Fig. 8, Oz-1e). We suspect that the dated sample, taken in the topmost part of the sediment succession, is locally redeposited by slope processes and thus solar-resettled.

Marine unit I; interpretation - The sediment sequence as observed at sites $\mathrm{Oz}-1 \mathrm{y},-1 \mathrm{z}$ and $-1 \mathrm{a}$ is interpreted as a transition from deeper-marine to a prograding deltaic deposition, with the increasing energy level reversing the clay/silt to sand bed thickness ratio with rising altitude. The deltaic progradation is also shown in gradually rising - but still moderate - bed dips and shift in depositional direction. Obviously the latter was directed by a palaeo-geography different than that of today as bed dip is preferentially up-valley with respect to present hydrography. The bulk of the sequence represents mid-delta to lower delta slope foreset facies, deposited from sediment gravity flows along deltaic lobes prograding to the NE. The predominant facies suggest that sandy density currents dominated in transporting the sediments down-slope. Direct suspension sedimentation from fully turbulent flows is indicated by the frequently occurring Sng and Sm beds, the S3 sandy turbidite division of Lowe (1982), whereas the Spp beds suggest a bed-load traction stage before deposition, the S1 sandy turbidite division of Lowe (1982). Successions continue into ripple-laminated sand and eventually fine sand and silt drapings ( $\mathrm{Sng} \Rightarrow \mathrm{Sr} \Rightarrow$ $\mathrm{Sm} / \mathrm{Sim}$ ), thus forming complete Bouma turbidite sequences (Bouma 1962), gradually deposited during waning flow events. The few inversely graded beds indicate laminar mass flows, set of due to slope failure, with dispersive pressure as the main grain support mechanism (e.g. Nemec, 1990) before sediment flow collapse/freeze (S2 sandy turbidite division; Lowe 1982). Some sediment gravity flows were channelled into delta slope chutes with deposition of a gravelly sandy load (GSm beds), though most coarse clasts are deposited as out-runners or as drop-stones. In distal direction thin sand beds, deposited from more distal sediment gravity flows, interfinger with bottomset marine muds, deposited from suspension settling.

The benthic foraminiferal assemblages in M-I are relatively diverse and dominated by arctic species such as Cassidulina reniforme, Elphidium excavatum f. clavata and Elphidium hallandsense. Other abundant species include Haynesina orbiculare, which are currently found in riverproximal environments in the Kara and Laptev Seas (Bude, 1997; Polyak et al., 2002) as well as the higher salinity demanding Islandiella norcrossi, Miliolina and Trifarina fluens. The upwards decrease in higher salinity demanding, deeper-water species and the increase in E. albiumbilicatum, Haynesina nivea and Astrononion gallowayi indicates a lowering of the water depth and an increased depositional energy, as also indicated by the increasing grain size (Fig. 8). A significant feature of M-I sediment is also the relatively high frequencies of Elphidium ustulatum and particularly Islandiella inflata. Elphidium ustulatum is an extinct species (Gudina and Evzerov, 1973; Gudina and Levchuk 1989, as Toddinella lenticularis) and except for one occurrence in presumably Middle Weichselian deposits from northern Denmark (Lykke-Andersen, 1987), it is not found in deposits younger than Eemian in NW Europe. Although Islandiella inflata has been described from the present continental shelves of the northern seas and the 
Bering Sea (Gudina and Evzerov, 1973, as Cassandara inflata), it is not found in the area today (Polyak et al., 2002). In NW Europe its hitherto youngest appearance is in the Late Saalian (cf Seidenkrantz, 1993), although it was found by Lorange (1977) in Holocene sediments from the Barents Sea.

The stacked sequences of M-I massive clays, silts and fine sands at sections Oz-1c and -1e, showing an almost rhythmical sedimentation pattern, are interpreted as lagoonal sediments, possibly upwards shallowing as indicated by the benthic foraminifera, and deposited lateral to the main deltaic body of the M-I sediments at substantially shallower depositional depth. Trapped organic debris, driftwood and seaweed sunk and were incorporated with the clastic sediment load. Possibly due to a moderate sediment deposition rate, a habitat more favourable for a richer mollusc fauna was formed, contrary to the area of prograding delta sediments with a sparse fauna.

Till unit II and associated glaciotectonics; descriptionT-II is a consolidated, matrix-supported, massive, clastrich clayey silty diamicton, which can be correlated from section Oz-1z to $-1 \mathrm{a}$ and $-1 \mathrm{~b}$ (Fig. 8) with a maximum observed thickness of $1.75 \mathrm{~m}$. Striated clasts are abundant and the largest observed clast in section was $\sim 1 \mathrm{~m}$ in diameter, though diametres of $60-80 \mathrm{~cm}$ are more common. The diamicton has a low content of shell fragments. The lowermost part of the diamicton at site Oz-1a is intrabedded with thin sand and gravelly sand beds, subparallel to the lower boundary and showing small-scale bed folding. A sand bed in the lower part of the diamicton at Oz-1b also forms a fold structure, attenuated in a southerly direction and a large boulder in the contact with the underlying M-I sediments is associated with deformational structures in the sorted sediments and has a striated top surface, the striae orientated N-S. Two fabric analyses were carried out in T-II at site Oz-1b (Fig. 10). The lower shows larger spread but a statistically significant preferred long-axis orientation $\left(\mathrm{S}_{1}\right.$ eigenvalue 0.61$)$ towards $11^{\circ}$. The uppermost analysis $(\mathrm{Oz} 1 \mathrm{~b} / \mathrm{IIa})$ reveals a strong long-axis orientation $\left(\mathrm{S}_{1}\right.$ eigenvalue 0.78$)$, although the dip is inconclusive for stress-transfer direction (SSW or NNE).

The contact to underlying marine sediments is undulating but everywhere sharp, and at sites Oz-1a and $-1 \mathrm{~b}$ it is associated with deep-reaching deformation. At Oz-1a the M-I beds stand near-vertical (plunge $70-80^{\circ}$ towards north) but form a synclinal bending of the laminas at depth, the deformation reaching at least $4 \mathrm{~m}$ downward (Figs. 4F, G).

Fig. 10. Clast fabric and glaciotectonic data from Ozernaya River, site 1. Clast long-axis orientations from till units II, II and IV are plotted as Schmidt equal-area, lower-hemisphere projections. Calculated largest eigenvector $\left(V_{1}\right)$ and normalized eigenvalues $\left(S_{1}, S_{2}, S_{3}\right)$ according to Mark (1973). Measured glaciotectonic structures in M-I are according to Figs. 6G and $\mathrm{H}$ and plotted as Schmidt equal-area, lower-hemisphere projections. Measured striae on clasts in T-III are plotted in a bidirectional rose diagram. Interpreted ice-flow and induced stress directions are shown by large arrow in each plot.
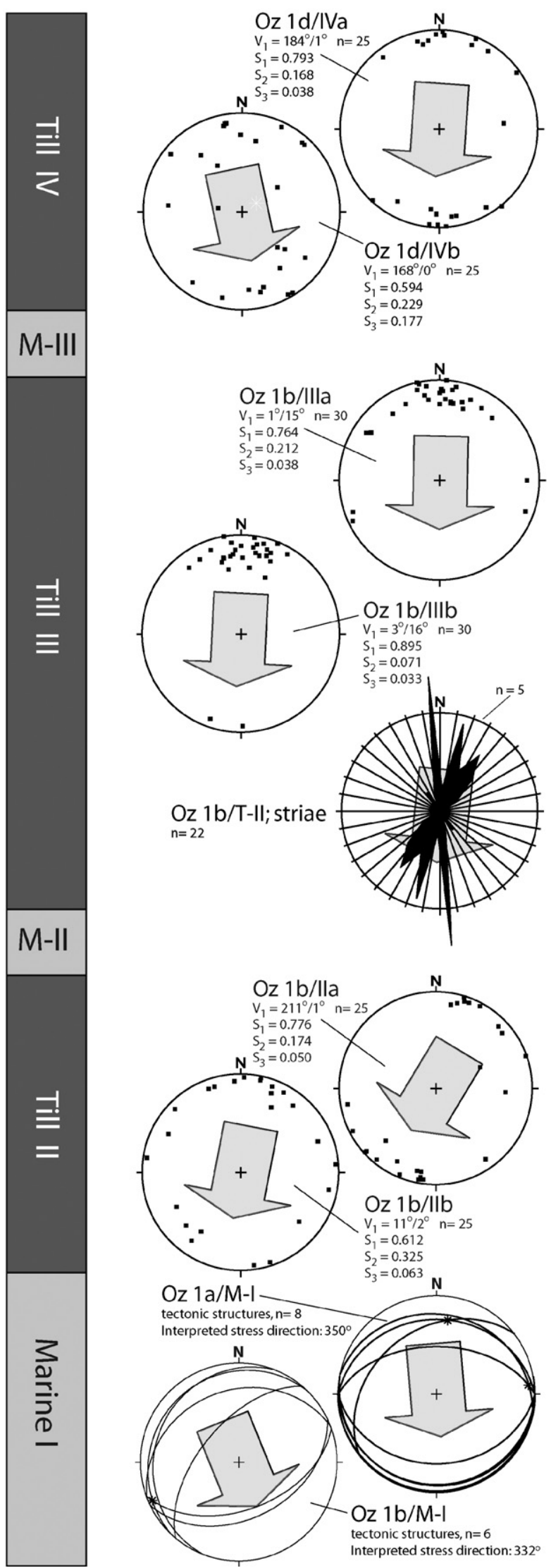


\section{Ozernary River}

Foraminiferal species, Marine unit I

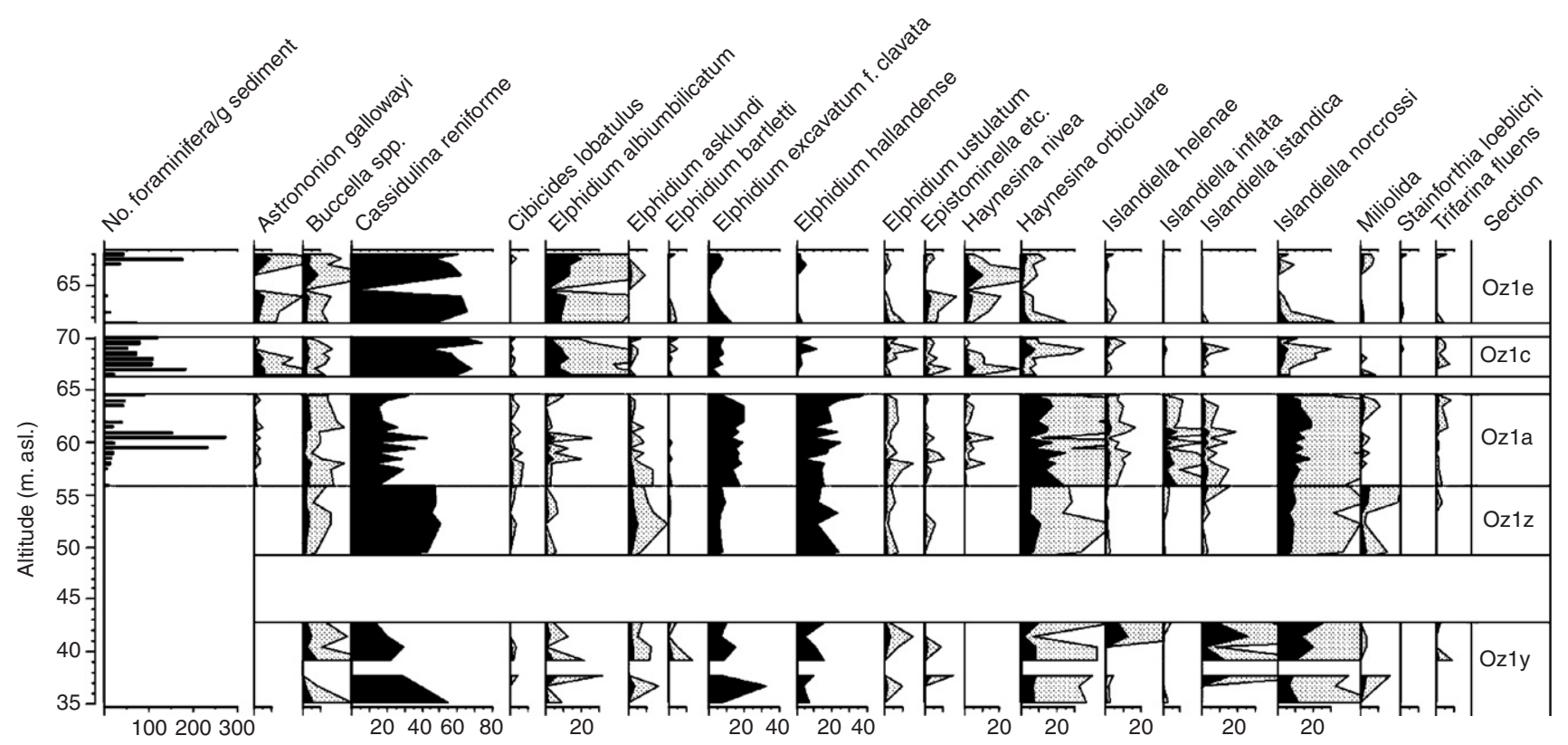

Fig. 11. Total number of benthic foraminifera and relative frequencies of selected foraminiferal species from M-I at sites Oz-1y, -1z, -1a, -1c and -1e. The relative frequencies of all species are shown on the same scale (black curves) and for many of the species, a $5 \times$ exaggeration (grey fill) is also shown in order to illustrate the often significant variations in the less frequent species. Only species which are significant in at least one section are selected. Grouped as Buccella spp. are Buccella frigida, Buccella hannai arctic and a few specimens of Buccella frigida calida and Buccella tenerimma. "Epistominella, etc." represents a group of species including Epistominella takayangii, Epistominella vitrea, Eoeponidella pulcella and Glabratella arctica, while "Haynesina nivea" also includes some specimens of Haynesina depressula (Table 2). The sites are presented according to altitude and presumed stratigraphical order, although the sediments from Oz-1c and -le may be of the same age. Note that there is a change in the altitude scale between sites Oz-1c and -1e.

The folded sediments are cut off, but also set off at depth, by a series of linear normal faults plunging in a southerly direction. Tectonic structures (Fig. 10) suggest a deformational stress from north. At Oz-1b, high-plunging M-I beds are overturned in a drag-fold (Fig. $6 \mathrm{H}$ reaching $\sim 1.5 \mathrm{~m}$ below the contact to above-lying diamicton, indicating a deformational stress from NNW (Fig. 10).

Till unit II; interpretation-The diamicton is interpreted as a subglacially deposited till, the intralamination of sand and deformed sorted sediment bodies in the basal part of the sequences representing shear banding and folding of incorporated sediment from the underlying $M-I$ in a deforming bed zone (e.g. Benn and Evans, 1996). Such stratification implies moderate strain rates during deposition of the lower portion of the diamict unit, which is supported by a girdle-shaped fabric. The increasing massiveness upwards suggests increasing strain rates with total homogenization of the deforming bed. The deforming bed was probably thin with gradual vertical accretion due to frictional freezing of sediment. This is indirectly indicated from fabric data; unimodal and clustered fabric shapes are suggested to be indicative of thin deforming-bed zones (Hart 1994; Benn, 1995; Hart and Rose, 2001) undergoing ductile shear (Boulton and Hindmarsh, 1987; Benn and Evans, 1996). The lower bed contact and deformational structures beneath it suggest ductile nonpenetrative deformation of M-I sediment, resulting in large-scale folding to varying depths. At site Oz-1a, the deformational structures imply proglacial isoclinal compressional folding of the strata, later eroded as marked by the present diamict/sand bed contact and then subjected to extensional faulting in the applied stress direction. All structural data taken together imply that ice movement direction was from a northern sector during deposition of Till II, thus also suggesting deposition during expansion of the local ice cap(s) (Fig. 10).

Marine unit II; description-The M-II sediments are exposed in sections Oz-1a and $-1 \mathrm{~b}$, in the latter section with a total thickness of $7 \mathrm{~m}$ (Fig. 8). The basal part constitutes clast-rich massive silty clay, grading into vaguely laminated to massive silty clay, the lamination due to thin coarse silt and fine sand intrabedding (Figs. 6I and L). Single floating clasts occur as well as one horizon enriched in pebbles and mollusc fragments. The upper part of the sequence reveals an increasing frequency of massive fine sand intrabeds $(2-5 \mathrm{~cm})$. Molluscs in differing preservation states occur throughout the succession, but with a pre-dominance of paired bivalves in the upper part (Mya truncata, Hiatella arctica and Macoma calcarea). A mollusc-rich sand bed at Oz-1a also contained Astarte elliptica, Astarte warhami, Serripes groenlandicus (Fig. 6J) and Portlandica arctica. The foraminiferal fauna of M-II is best developed at site Oz-1b (Fig. 12) with Cassidulina reniforme dominating the fauna through the entire section. Important additional taxa 


\section{Ozernary River}

Foraminiferal species, Marine unit II, III \& IV

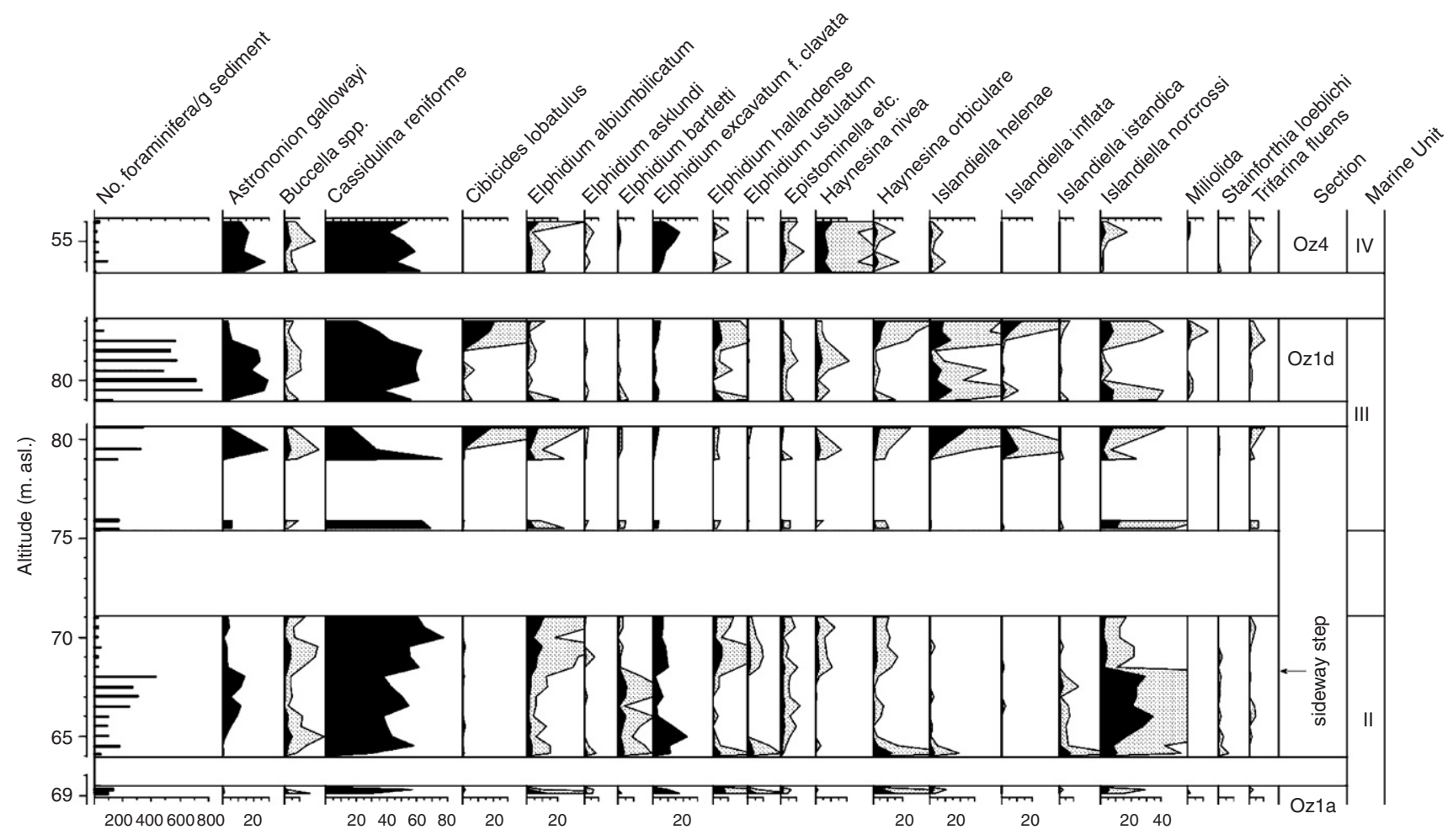

Fig. 12. Total number of benthic foraminifera and relative frequencies of selected foraminiferal species from Marine units II, III and IV at sites Oz-1a, -1b, $-1 \mathrm{~d}$ and $\mathrm{Oz} 4$. The relative frequencies of all species are shown on the same scale (black curves) and for many of the species, a $5 \times$ exaggeration (grey fill) is also shown in order to illustrate the often significant variations in the less frequent species. For explanation on foraminiferal groupings, see Fig. 11. The sites are presented according to stratigraphical order and the altitude of each section is given to the left. Note that there are several changes in the altitude scale. An arrow marks the location of the approximately $170 \mathrm{~m}$ long side-ways step between two subsections during the sampling of M-II at site Oz- $1 \mathrm{~b}$.

in the lower part are, e.g. Islandiella islandica and Haynesina orbiculare, changing to Islandiella norcrossi, Astrononion gallowayi and Elphidium bartletti in the middle part of the section and again to Elphidium albiumbilicatum, Elphidium hallandense and Haynesina orbiculare in the upper part.

Chronology-A single shell valve yielded the ${ }^{14} \mathrm{C}$ age of $>50$ cal ka (Table 3) and quartz grains yielded a single GSL age of $>152 \mathrm{ka}$ (Table 6). Four out of five ESR dates come out consistently around $220 \mathrm{kaBP}$, just with one outlier at $150 \mathrm{ka} \mathrm{BP}$ (Table 5). The average $\mathrm{D} / \mathrm{L}$ Asp ratio is $0.25 \pm 0.02(n=14)$ (Table 7; Fig. 9).

Marine unit II; interpretation-The lower part of M-II is dominated by the deposition of fine-grained sediment $(\mathrm{SiCm})$ out of suspension from the water column and at considerable water depths. The marked frequency change of floating out-sized clasts suggests a glacio-marine, possibly deglacial environment, changing into a marine environment with just sporadic delivery of ice-rafted clasts. The gradually more frequent intrabeds of sand in the upper part are interpreted to have been deposited from highdensity turbidity currents, possibly generated during storm events (e.g. Elliot, 1986). This also indicates a transition from an off-shore to a lower shoreface depositional environment, probably due to glacioisostatic uplift. The fossil mollusc fauna of M-II resembles the present-day high-arctic mollusc fauna in the region (S. Funder, personal communication, 2004).

The environmental changes, as indicated from the sediment succession, are supported by the changes in the foraminiferal fauna of M-II, in general illustrating a regressive succession. In the lowermost part the fauna is particularly characterized by Islandiella islandica, Haynesina orbiculare and some Elphidium asklundi, the later two of which are today found in river-proximal regions of the Kara and Laptev Seas (Bude, 1997; Polyak et al., 2002) and thus indicating somewhat reduced salinities that can be due to the melting glaciers at the end of a glaciation/stadial. The low but significant presence of Stainforthia loeblichi may be ascribed to seasonal sea-ice cover (see Steinsund et al., 1994). This concurs with the high content of icerafted material in the sediment, indicating a glaciomarine environment.

The middle part of the section is characterized by Islandiella norcrossi, Astrononion gallowayi and Elphidium bartletti, indicating less fresh-water input and salinities $>33 \%$, which is supported by the disappearance of icedropped material. A peak of the opportunistic species Elphidium excavatum f. clavata (Fig. 12) may illustrate unstable conditions. The foraminifera represent relatively 
deep-water conditions $(>40-50 \mathrm{~m})$, superposing the till (T-II), and suggest a deglacial flooding.

A significant change in the faunal composition is seen at $68.25 \mathrm{~m}$ a.s.1., a level where we had to side step $\sim 170 \mathrm{~m}$ from one subsection to another to continue sampling (marked with an arrow in Fig. 12). The faunal change at this level, which could not be recorded in the sediment succession, may indicate a hiatus of unknown length. The section above this horizon is characterized by relatively shallow-water species such as Elphidium albiumbilicatum, Elphidium hallandense, Haynesina nivea and Haynesina orbiculare, indicating a reduced water depth as supported by the presence of fine-sand layers and reduced bottomwater salinities (30-32\%o), at least during spring and summer, when freshwater outflow was at a maximum. An increased freshwater supply may also explain the relatively high frequencies of Buccella spp., possibly related to an increased nutrient supply. The short interval of M-II at site Oz-1a can presumably be correlated to the lower or middle part of M-II at Oz-1b. Notably, Elphidium ustulatum occurs in the intervals of somewhat reduced salinities in MII, whereas Islandiella inflata, found in M-I and M-III (see above and below), is absent.

Till unit III; description-T-III is a compact, matrixsupported, clast-rich clayey silty diamicton, exposed in sections Oz-1b and -1d (Fig. 8) with a maximum observed thickness of $4.5 \mathrm{~m}$. The contact to underlying M-II clay is sharp with no observable mixing or deformation (Fig. 6L). The diamicton has a low content of shell fragments in its basal part and shell fragments were not observed higher than $0.5 \mathrm{~m}$ above the basal contact. Clasts, the largest in section $30-40 \mathrm{~cm}$, are often striated. Measured clast striae cluster in $\mathrm{N}-\mathrm{S}$ directions (Fig. 10). The diamicton has an overall massive appearance, especially in its lowermost part, but becomes subhorizontally stratified in three distinct zones with $1-4 \mathrm{~cm}$ thick and tightly clustered reddish layers (Fig. 6K). Two fabric analyses were carried out in T-III at site Oz-1b (Fig. 10, Oz 1b/IIIa and b), revealing unimodal and clustered fabric shapes with strong long-axis orientations $\left(S_{1}\right.$ eigenvalues 0.76 and 0.90$)$. The $V_{1}$-axis orientations (azimuth $3^{\circ} / 16^{\circ}$ and $1^{\circ} / 15^{\circ}$ ) suggest a stress-transfer direction from north.

Till unit III; interpretation-The diamicton is interpreted as a subglacially deposited till. The sharp boundary to the underlying M-II sediments, showing no signs of glacially induced deformation/folding in the subhorizontal primary bedding, as is the case for the M-I sediments is probably due to the very different rheological/shear strength properties; all shear stresses seem to have been released along a decollément plane - the sharp basal boundarywith no stress transfer downwards into the sediments beneath T-III.

The diamicton varies in structure between massive and a reddish banding, the latter due to sheared-out clasts of weaker lithologies, indicating a high strain. High strain during deposition of T-III is also indicated from unidirectionally striated clasts within the diamicton and the tightly clustered pebble fabrics with substantial up-glacier imbrications. All sedimentary properties of the diamicton indicate vertical accretion of the till bed from freezing of thin deforming bed units and the till could be interpreted as a classical lodgement till. The structural data imply that ice movement direction was from a northern sector towards south, thus suggesting deposition during expansion of the local ice cap(s).

Marine unit III; description-M-III sediments are exposed between T-III and T-IV in section Oz-1b $(5.2 \mathrm{~m})$ and $-1 \mathrm{~d}(4.3 \mathrm{~m})$ (Fig. 8). Both sections reveal similar patterns of upwards coarsening and facies change. The succession starts with clast-rich $(1-5 \mathrm{~cm})$ massive silty clay. The frequency of dispersed clasts become lower upwards and clasts are markedly well rounded in the uppermost part of the succession. Clasts occur also in more continuous gravel-cobble horizons, accompanied with concentrations of shell fragments (Fig. 6O). At Oz-1d the succession gradually coarsens upwards with massive fine sand with dispersed floating pebbles interbedded with thin massive silt beds, followed by massive to vaguely stratified sand and gravelly sand and matrix- to near-to clast-supported sandy gravel. The latter change becomes more abrupt at Oz-1b. Paired, in situ bivalves are abundant in the uppermost parts of M-III sediment (Mya truncata, Hiatella arctica, Astarte warhami, Astarte montagaui and Astarte borealis dominate but with Serripes groenlandicus, Ciliatocardium ciliatum and Macoma calcarea also present), and a number of burrow traces were identified (Fig. 6P). One find of the subarctic gastropod Buccinum undatum also shows traces of Balanus crenatus and burrows from Polydoria ciliata on its shell surface.

At site Oz-1d the foraminiferal fauna of M-III may be divided into three sections (Fig. 12). In the lower part (79.0-79.75 m a.s.1.) the fauna is, in addition to Cassidulina reniforme, characterized by Islandiella norcrossi, Islandiella helenae, Elphidium hallandense and Elphidium albiumbilicatum. The middle part (79.75-81.75 $\mathrm{m}$ a.s.1.) is characterized by Cassidulina reniforme, Astrononion gallowayi, Haynesina nivea and Epistominella, whereas the uppermost part (81.75-80.60 m a.s.1.) has a diverse fauna including Islandiella norcrossi, Islandiella helenae, Haynesina orbiculare, Elphidium hallandense and Cibicides lobatulus.

Chronology - One of two mollusc samples yielded an infinite ${ }^{14} \mathrm{C}$ age (>54 cal ka) and the other is close to infinite $(51 \mathrm{cal} \mathrm{ka})$ and should be treated with caution (Table 3). The average $\mathrm{D} / \mathrm{L}$ Asp ratio is $0.20 \pm 0.02(n=42)$ (Table 7; Fig. 9). Four ESR ages cluster between 80 and $89 \mathrm{ka}$ BP (Table 5), whereas six out of seven GSL ages cluster between 143 and 176, with one outlier at $225 \mathrm{ka}$ (Table 6).

Marine unit III; interpretation-The lower part is predominated by deposition of fine-grained sediment $(\mathrm{SiCm})$ out of suspension and at considerable water depths, intercalated with probably storm-induced turbidite beds, as indicated from floating coarse clasts in a sand matrix and enrichments in shell fragments (Fig. 6O). The pronounced 
but gradual vertical sediment fining $(\mathrm{SiCm} \Rightarrow \mathrm{Cm})$ and frequency-reduction in floating out-sized clasts suggests a glacio-marine deglacial environment, changing into a marine off-shore environment with sporadic delivery of IRD. An upward change into interlaminated silts and sands and eventually into massive and laminated gravelly sand and sandy gravel, all associated with an abundant mollusc fauna, suggest a transition from off-shore to shoreface and eventually foreshore depositional environments, and thus a full isostacy-driven regressional sediment sequence. The predominating mollusc assemblage is a typical high-arctic community. However, the occurrences of Buccinum undatum (present occurrence is further south in the Kara Sea, off Yamal Peninsula) and Balanus crenatus suggest somewhat warmer waters than presentday Holocene conditions (S. Funder, personal communication, 2004). The foraminiferal fauna changes support the interpretation of sedimentary environmental changes, suggesting a full regressional cycle. In the basal part Cassidulina reniforme, Islandiella norcrossi and Islandiella helenae suggest deposition in relatively deep water (>30-40 m) above the till (T-III), and Elphidium hallandense and Elphidium albiumbilicatum indicate freshwater influx presumably from melting glaciers, as indicated by abundant drop-stones in the fine-grained sediment. In the middle part of MIII Cassidulina reniforme, Astrononion gallowayi and Epistominella infer a decreased meltwater flux. This is followed by reduced water depth and lower salinity during forced regression, as indicated in the upper part of the section by shallow-water, lower salinity species such as Haynesina orbiculare and Elphidium hallandense, while high frequencies of Cibicides lobatulus suggest increased energy-level. High energy may also explain the influx of Miliolina, which may have been washed in from the open sea.

The occurrence a few specimens of Trifarina cf. angulosa (an intermediate form between the cold Trifarina fluens and the boreal Trifarina angulosa; not shown on Fig. 12) in section Oz-1b may indicate some influence of Atlantic water in the offshore area. Trifarina angulosa is today found in the region influenced by Atlantic water off the coast of NW Norway; Hald and Steinsund, 1992), although it may also be found in areas of high-energy environments near Greenland (MSS unpublished data) and Antarctica (Mackensen et al., 1995; Mackensen, 1997). M-III contains Islandiella inflata and a few Elphidium ustulatum.

Till unit IV; description-T-IV is a compact, matrixsupported, massive clayey silty diamicton which is exposed in sections Oz-1b and -1d (Fig. 8) with a maximum observed thickness of $0.7 \mathrm{~m}$. The contact with the underlying M-III sand is sharp but the lowermost $15 \mathrm{~cm}$ of the diamicton carries frequent thin sand beds and also intraclasts (Fig. 6M) of the same lithology as the M-III sand. The basal part of the diamicton is also rich in wellrounded gravel to cobble-sized clasts, a few of the latter showing striation in north-south direction on the upper surface. Striated clasts are also common further up in the diamicton (Fig. 6N).

Two fabric analyses were carried out in T-IV (Fig. 10). Fabric analysis from the lower, sand-interbedded part of the diamicton shows a unimodal but weakly clustered fabric shape $\left(S_{1}=0.59 ; V_{1}\right.$-axis azimuth $\left.168^{\circ} / 0^{\circ}\right)$, whereas analysis from the upper part of the diamicton reveals a tightly clustered fabric shape $\left(S_{1}=0.79 ; V_{1}\right.$-axis azimuth $184^{\circ} / 1^{\circ}$ ).

Till unit IV; interpretation-The diamicton is interpreted as a subglacial till. M-III sediments are incorporated into the lower part of T-IV, both as a part of the clast population with still recognizable beach pebble and cobble lithologies, sand intraclasts, and as sheared-out sand intrabeds. This shear banding and intermixing disappears upwards, indicating cut-off from the underlying sediment source and a higher degree of homogenization of the deforming bed. The fabric shape shows the same vertical pattern as in T-II, i.e. upwards increasing clustering of the pebble fabric, which can be interpreted as a result of increasing strain during the vertical accretion of the till bed. The structural data shows an ice movement orientation $(\mathrm{N}-\mathrm{S})$ but is inconclusive with regards to ice movement direction (north or south) due to the subhorizontal axial planes.

Fluvial unit I; description-The M-II sediments at site Oz-1a are overlain by a more than $10 \mathrm{~m}$ thick unit of sandy to cobbly gravel, reaching $80-85 \mathrm{~m}$ a.s.l. (Fig. 8). However, due to a combination of the unstable nature of the gravel and the shallow depth to permafrost, the contact to M-II sediments could not be excavated. The cleared sections repeatedly collapsed before sedimentary structures and bed geometry could be documented. This unit thins out towards the north and is not present at site Oz-1b, whereas it forms a thickening, topmost unit towards the south (Fig. 6 $\mathrm{A}^{1}$ ). These relations suggest sediment infill in an erosional basin, cut down into T-IV and older sedimentary units, forming the youngest sediments at the Ozernaya 1 site.

Fluvial unit I; interpretation - It is difficult to forward an environmental interpretation of this unit due to lack of observable sedimentologic features. However, this unit probably reflects fluvial deposition with post-glacio-isostatic emergence.

\subsection{Ozernaya River, sites 2 and 3}

These sites are situated on a gravel plateaux at 90-110 m a.s.1., flanking the Ozernaya River (Fig. 5). The $\mathrm{Oz} 2$ site is in a ravine cut by a small side-stream to the Ozernaya River, which has left a $2 \mathrm{~m}$ high section. The $\mathrm{Oz} 3$ site is a $5 \mathrm{~m}$ high section, cut by the Kruzhilikha River, a tributary to the Ozernaya River (Fig. 5). In both cases, the upper plateau surface nearby includes several $1 \mathrm{~m}$ high beach ridges, too small and subtle to be discerned in satellite or aerial images.

Sediment description - Both sections (Figs. 13 and 14) reveal coarsening upwards successions. Oz 2 site has 


\section{Ozernaya River 2}

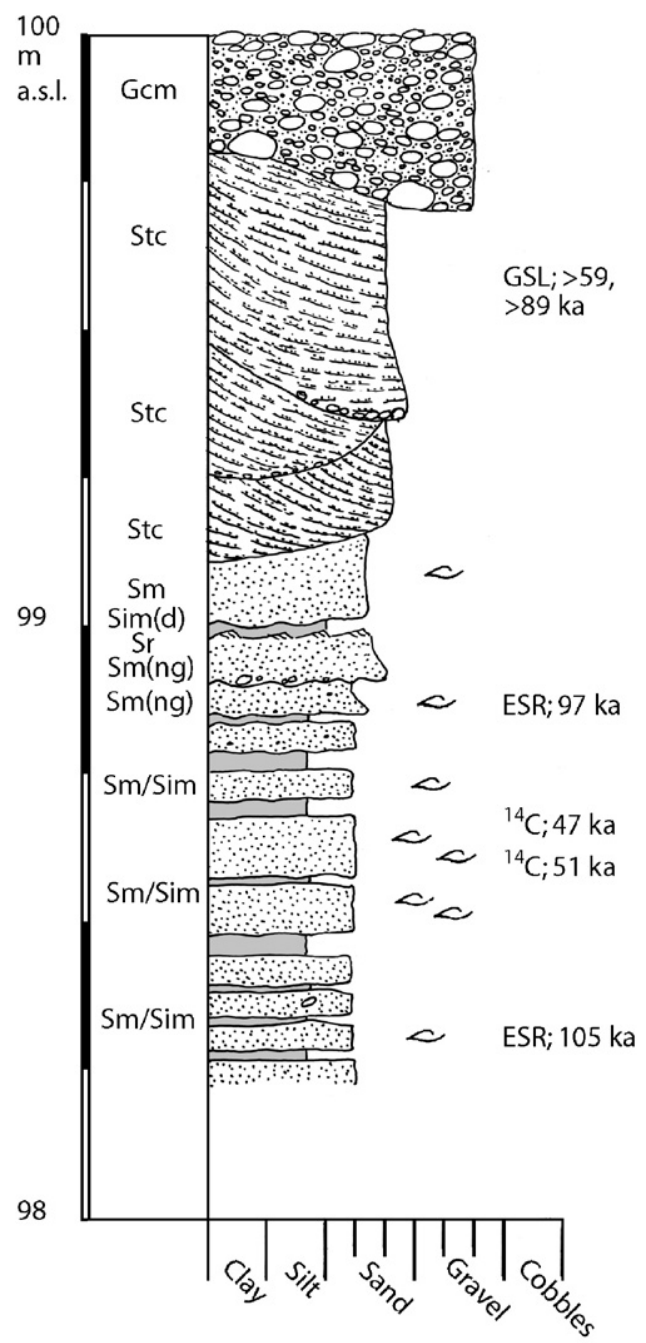

Fig. 13. Stratigraphic log for the Ozernaya River site 2 (Oz 2; Fig. 5 for location).

$5-10 \mathrm{~cm}$ thick massive sand beds, interbedded with $1-4 \mathrm{~cm}$ thick massive silt beds. Occasionally the sand beds show normal grading and ripple-laminated or erosive, pebblestrewn upper surfaces. All beds have rich in situ fossil molluscs, predominantly Macoma calcarea, Hiatella arctica and Mya truncata. The sequence is terminated upwards with trough cross-laminated sand and clast-supported gravel. The succession at the Ozernaya 3 site starts with massive clay and clayey silt with occasional floating clasts $(1-3 \mathrm{~cm})$, interbedded with thin intrabeds of massive sand. A bedset of trough cross-laminated sand is followed by laminated silt, erosively cut and overlain by a $3.5 \mathrm{~m}$ thick unit of massive gravelly sand and sandy gravel, rich in wellrounded pebbles and with occasional floating boulders (maximum size $0.5 \mathrm{~m}$ ). The fine-grained lower part of the sequence carries rich in situ fossil molluscs, predominantly Hiatella arctica and Mya truncata, whereas the gravelly upper part carries fragmented mollusc shells.

\section{Ozernaya River 3}
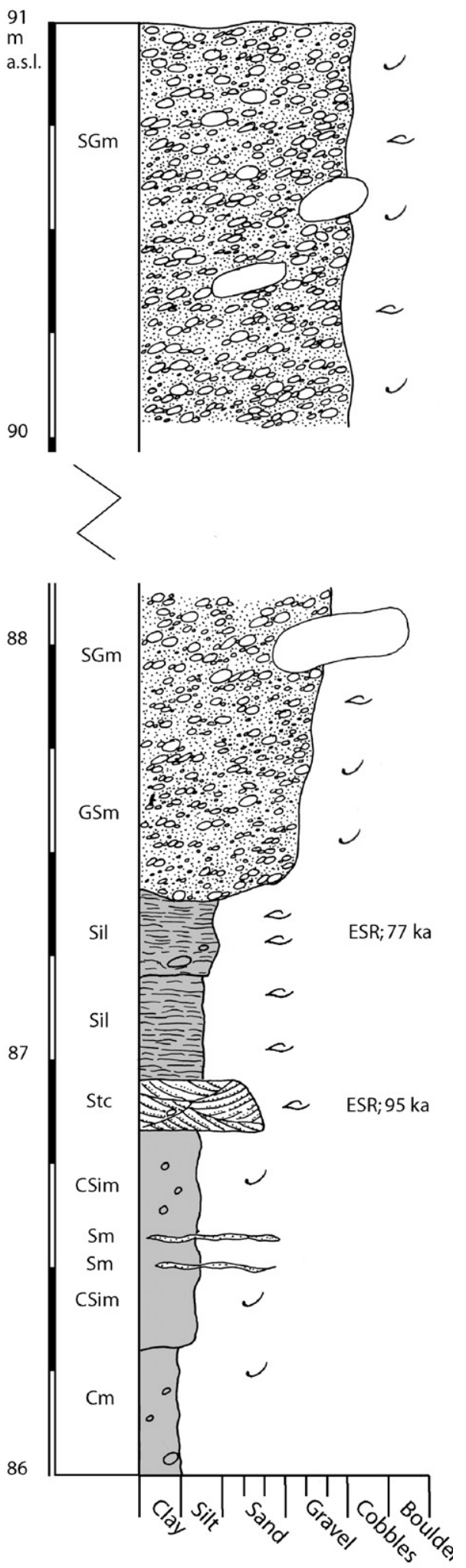

Fig. 14. Stratigraphic log for the Ozernaya River site 3 (Oz 3; Fig. 5 for location). 
Chronology-We regard two ${ }^{14} \mathrm{C}$ ages of 47 and $>51 \mathrm{cal}$ ka on molluse shells from $\mathrm{Oz} 2$ as infinite in age (Table 3). The average $\mathrm{D} / \mathrm{L}$ Asp ratio is $0.19 \pm 0.02(n=17)$ (Table 7; Fig. 9), which is similar ratios in M-III sediments elsewhere. Four ESR samples suggest an age of 97-105 ka, whereas ESR samples at the $\mathrm{Oz} 3$ site may indicate a slightly younger age, 77-95 ka BP (Table 5), but overlap at 2 sigma and thus are not statistically different. Two GSL samples yield ages of $>59$ and $>96 \mathrm{ka}(\mathrm{Oz} 2$ site; Table 6$)$, and do thus not contradict the other geochronological results.

Sedimentological and environmental interpretation-The Oz 3 massive to laminated clays and silts with floating outsized clasts suggest gradually shallowing off-shore marine conditions, with interbedded sands representing storm events. The $\mathrm{Oz} 2$ interlaminated silts and sands $(\mathrm{Oz} 2)$ with an abundant mollusc fauna, followed by crosslaminated sands and clast- to matrix-supported sandy gravels suggest transition from offshore to shoreface and eventually to a foreshore/beachface environment. The transition to a beachface environment at the $\mathrm{Oz} 3$ site seems to follow an erosional event. Although these regressional sediment sequences does not contain identifiable tills they are correlated with Marine unit III at the Ozernaya $1 \mathrm{~b}$ and $1 \mathrm{~d}$ sites (Fig. 8), based on similarities in sedimentology, altitude, and ESR and $\mathrm{D} / \mathrm{L}$ Asp results for the enclosed molluscs.

\subsection{Ozernaya River, high shoreline sites}

A series of six surficial-sampling sites (Fig. 5; localities between three sites marked 'asp') lie on the seaward flank of a prominent several-metre high beach escarpment at $\sim 125 \mathrm{~m}$ a.s.l. (Figs. $17 \mathrm{D}$ and E). At the base of the escarpment, the surface is veneered in gravel and cobbles, fining seawards. The escarpment is mostly composed of limestone bedrock, frost shattered in place. Although no outcrops could be found, shell fragments (mostly Hiatella arctica) were present at the surface of all six sites. A few hundred metres to the north is the highest shoreline at $\sim 140$ m a.s.l. (Fig. 17D), in places a broad gravel beach terrace (depositional landform) and elsewhere a steep 2-10 $\mathrm{m}$ high erosional escarpment with a veneer of cobbles and gravel being highest in the easternmost $\sim 2 \mathrm{~km}$ stretch nearest the Vavilov Ice Cap. Both shorelines clearly continue below the present Vavilov Ice Cap, suggesting a smaller than present ice cover at the time of shoreline formation (Fig. 5).

Chronology - Mollusc shell fragments yield an average $\mathrm{D} / \mathrm{L}$ Asp ratio of $0.19 \pm 0.01$ (Table 7; Fig. 9). An additional shell with $\mathrm{D} / \mathrm{L}$ Asp of 0.28 is considered an outlier and may reflect re-working from older deposits or exposure to higher temperatures at the surface for an unknown period of time.

Environmental interpretation - The high shoreline sites at 118-125 ma.s.l., being predominantly erosional terraces, probably reflect a storm beach rather than a shoreface environment. Collected shell fragments show a consistent $\mathrm{D} / \mathrm{L}$ Asp ratio of 0.19 , identical to the ratios at marine terrace sites $\mathrm{Oz} 2$ and $\mathrm{Oz} 3$ at $90-110 \mathrm{~m}$ a.s.l. Thus, the high shorelines and the $\mathrm{Oz} 2$ and $\mathrm{Oz} 3$ sites probably correlate with regressional M-III sediments at the $\mathrm{Oz}-1 \mathrm{~b}$ and $-1 \mathrm{~d}$ sites (Fig. 8) because of similar chronologies and elevations. The uppermost sediments of $\mathrm{M}$-III at site $\mathrm{Oz} 1$ were deposited in a similar environment too; they form a marine terrace at $\sim 80 \mathrm{~m}$ a.s.l. which, however, is patchily covered with diamicton of Till unit IV. The morphology of the undated $\sim 140 \mathrm{~m}$ a.s.l. shoreline is similar to that of the $125 \mathrm{~m}$ shoreline, suggesting a similar age. In all likelihood, the marine landforms from $140 \mathrm{~m}$ down to at least $80 \mathrm{~m}$ a.s.l. span a single regressive cycle.

\subsection{Ozernaya River, sites 4 and 5}

Site $\mathrm{Oz} 4$ is an erosional remnant of interbedded silts, clays and fine sands on the west bank of the Ozernaya River (Fig. 5), starting at $\sim 60 \mathrm{~m}$ a.s.l. and exposed in a system of gullies eroded by water flows and solifluction (Fig. 15). The base of the sequence overlies a till at $45 \mathrm{~m}$ a.s.1., but only $3 \mathrm{~m}$ of the upper part of the succession could be logged as the general bed dip of $3-4^{\circ}$ parallels the slope. The surface carries a dispersed lag of sometimes striated pebbles and small cobbles, out-sized clasts that are not present in the logged sequence. A pod of closely spaced and almost complete skeletons of at least 9 narwhals (Monodon monoceros Linné.; Figs. 17A and B) are presently in the process of eroding out of the sediment surface at $\sim 50 \mathrm{~m}$ a.s.l. (first described by Bolshiyanov and Makeyev, 1995). Site $\mathrm{Oz} 5$ is a small section below a terrace at $\sim 60 \mathrm{~m}$ a.s.l. on the east bank of the Ozernaya River (Fig. 5). The section is just $1.25 \mathrm{~m}$ high (Fig. 16) and also here the top surface carries a dispersed lag of sometimes striated pebbles and small cobbles.

Description-The upper $2.5 \mathrm{~m}$ of the $\mathrm{Oz} 4$ section reveal a repeated pattern of stacked cosets of fine sand to coarse silt, interbedded with thin beds $(0.2-1 \mathrm{~cm})$ of massive clay and cosets of massive silty clay, interbedded with thin beds $(0.2-1 \mathrm{~cm})$ of massive fine sand (Fig. 17E). The sequence thus shows a rhythmical sedimentation pattern, consisting of 120 fine sand/silty clay couplets. Just one in situpositioned paired mollusc shell was encountered which splintered during extraction into non-identifiable pieces. The lowermost part revealed no internal lamination but just interbedding between thicker units of silt and clay; however, this part was wet and near permafrost and possibly internal lamination was obscured. The underlying till, a massive silty clayey diamicton, is poorly exposed in the shallow gully. Its contact to the overlying silty clay could not be assessed due to permafrost.

The foraminiferal assemblage in this section is dominated by Cassidulina reniforme, with Astrononion gallowayi, Elphidium excavatum forma clavata and Haynesina nivea as assessory species (Fig. 12). Other taxa include a.o. Haynesina orbiculare, Elphidium albiumbilicatum, Elphidium 


\section{Ozernay River 4}
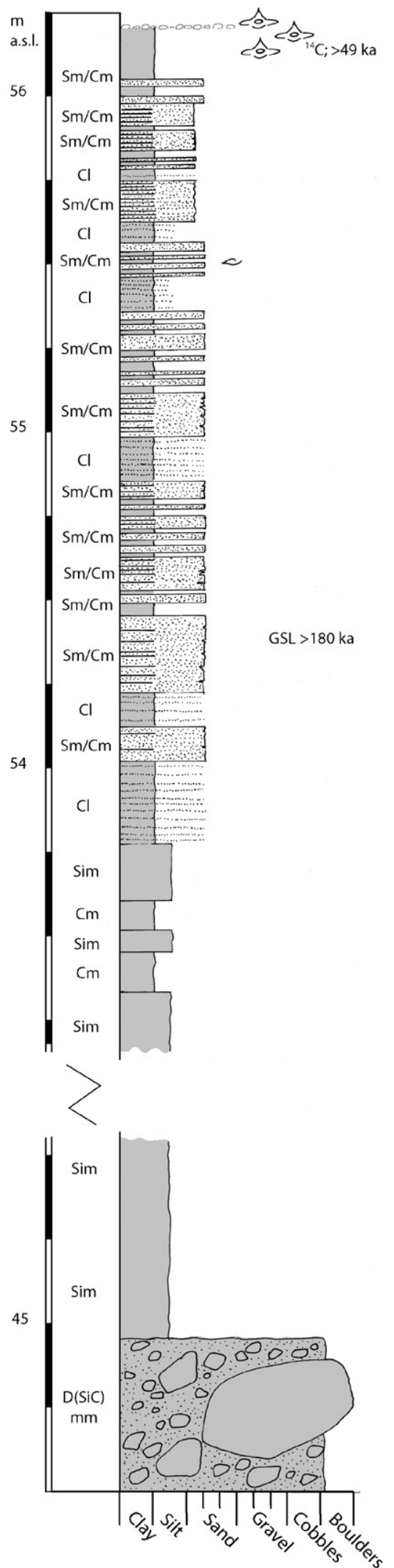

Fig. 15. Stratigraphic log for the Ozernaya River site 4 (Oz 4; Fig. 5 for location). hallandense, Islandiella norcrossi and Islandiella helenae in lower numbers. This species composition shows a mixed high- and low-salinity fauna. Notable is also the absence of Islandiella inflata and Elphidium ustulatum.

The sediment sequence at the $\mathrm{Oz} 5$ site (Fig. 15) resembles that described above for site $\mathrm{Oz} 4$, but is thinner. These sediments are also poor in molluscs; however, one paired shell of Hiatella arctica and several Portlandia were recovered from the section. Within $100 \mathrm{~m}$ of the section and a few metres higher in elevation lies a small patch of similar sediment with several Hiatella arctica and Astarte molluscs lying half-exposed at the surface, still oriented in situ.

Chronology-Dating possibilities for these sites are limited due to sparseness of dateable material. A narwhal tusk at site $\mathrm{Oz} 4$ yields a finite ${ }^{14} \mathrm{C}$ age of ca $50 \mathrm{cal} \mathrm{ka}$, which should be considered a minimum due to multiple boneprocessing steps that could add small amounts of modern carbon. A single GSL sample yields a substantially higher age, $>181 \mathrm{ka} \mathrm{BP}$. At site $\mathrm{Oz} 5$, a single shell is ESR-dated to $59 \mathrm{ka} \mathrm{BP}$ while two ${ }^{14} \mathrm{C}$ samples yield ages of 45 and $47 \mathrm{cal} \mathrm{ka} \mathrm{BP}$. The average D/L Asp ratio of several shells is relatively low at $0.13 \pm 0.01(n=4$; Table 7 ; Fig. 9).

Interpretation - The uniform, rhythmical deposition of the fine-grained sediment at site $\mathrm{Oz} 4$ suggests a lowenergy, deeper-water environment. A possible palaeoenvironmental interpretation is a high-stand sea level ( $+65 \mathrm{~m}$ a.s.1.) with marine waters inundating the Ozernay River valley, forming a deeply embayed estuary behind a valley-mouth bar/barrier system. This environment would explain the mixed foraminiferal fauna of in situ and allochtonous specimens collected in this relatively deep basin. A high sediment input, and thus high sedimentation rate, from the subaerial part of the Ozernaya drainage system made the environment less favourable for bottomdwelling fauna, as indicated from the sparse occurrence of molluscs.

The closely spaced skeletons of the narwhals, lying all in the same stratigraphical position on the erosional top surface of deeper-water sediment, suggest that all were trapped when the Ozernaya palaeo-fjord froze over and sea ice became too thick and sealed their breathing holes. Such ice-trapping of narwhals (and other whales) is described from Greenland as "savssats" (Porsild, 1918; Rosing, 1986), there exploited by Inuits as the perfect hunting situation.

\subsection{Changeable lake sites}

The most prominent shoreline of southern October Revolution Island is found at $30-40$ ma.s.l., traceable in the field on aerial photographs and satellite images from west of Changeable Lake, across the Ozernaya River valley, to west of the University Glacier in the east, a distance of more than $70 \mathrm{~km}$ (Fig. 4). East of Changeable Lake (Fig. 18) it forms a broad high-lying beach terrace (depositional landform), occasionally with one or more discernable berm crests, elsewhere an erosional escarpment 


\section{Ozernay River 5}

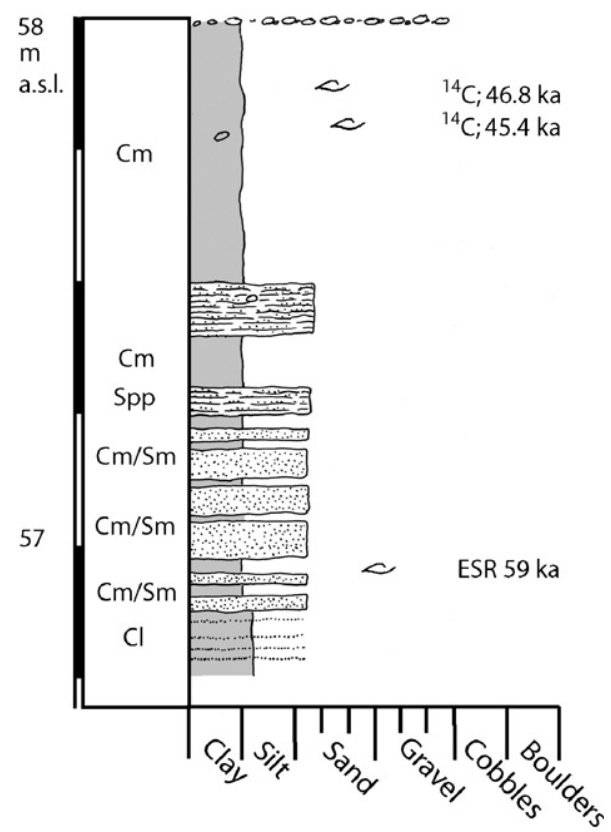

Fig. 16. Stratigraphic $\log$ for the Ozernaya River site 5 (Oz 5; Fig. 5 for location).

with a veneer of beach gravel. The gravels form low ridges over valleys and other basins, cut at numerous places by streams coming from the Vavilov Ice Cap. The unstable gravel deposits give, however, usually poor exposures of the internal sediments. The best-exposed sections are near Changeable Lake 1 (CL 1; Figs. 18 and 20A). There a $\sim 5 \mathrm{~m}$ high beach ridge overlies the limestone surface, and the beach sediments are traced down-slope towards the sea, at site CL 5 overlying marine clays and silts.

Description-The sediment sequence at site CL 1 (Figs. 18 and 19), a $\sim 5 \mathrm{~m}$ high beach ridge that overlies the limestone surface, shows preserved sedimentary structures only in the uppermost $1 \mathrm{~m}$. The sediments form an interbedded succession of massive sand with gravel stringers and clast-supported gravel. Some gravel beds reveal open-work frameworks and clast imbrications towards the south (Fig. 20B). The sediments are rich in mollusc shells, mostly fragmented, but paired in situ shells of Hiatella arctica are also found. Approximately $500 \mathrm{~m}$ to the south the river has cut a $1.5 \mathrm{~m}$ high section $(\mathrm{CL} \mathrm{5}$, Figs. 18 and 19) into clayey silt, rich in out-sized floating clasts and interbedded with massive sand beds, $3-7 \mathrm{~cm}$ thick (Fig. 20C). All beds are rich in paired, in situ positions molluscs, predominantly thick-shelled Hiatella arctica and Astarte borealis.

Chronology-Five ${ }^{14} \mathrm{C}$ ages, and three additional ${ }^{14} \mathrm{C}$ dated samples from nearby sites CL 3 and CL 4 (Fig. 18) cluster between 36.6 and $46.8 \mathrm{cal} \mathrm{ka} \mathrm{BP}$, ages that potentially could be finite (less than ca $52 \mathrm{cal} \mathrm{ka}$ ) and thus suggesting a Mid-Weichselian (MIS 3) age of this marine event. However, this suggestion is ambiguous as the oldest of them lie close to the limit of ${ }^{14} \mathrm{C}$ dating and all samples might be slightly contaminated by young carbon. These ${ }^{14} \mathrm{C}$ ages are inconsistent with three ESR ages of ca 29-32 ka age for the fine-grained sediments at site CL 5 and an even younger age of ca $20 \mathrm{ka}$ for the gravel deposits at site CL 1 . The average $\mathrm{D} / \mathrm{L}$ Asp ratio is a relatively low $0.14 \pm 0.01$ ( $n=3$; Table 7; Fig. 9).

Interpretation - The exposed sediments at site CL 1 are deposited in the wave-swash zone in a beachface environment, as suggested from open-work gravel frameworks and seawards-imbricated clasts. From morphology and position in the terrain it is evident that these beach deposits formed barriers across low-lying terrain and thus creating shallow lagoons on the backshore side during beach formation. The beach gravel deposits at $30-40 \mathrm{~m}$ a.s.l. form the highest-positioned unit of this set, followed by a more diffuse gravel deposition at lower altitudes during the regressional phase. At site CL 5 these beach gravels drape off-shore marine sediments from the same marine sequence.

\subsection{Ozernaya river delta sites}

Three sediment successions were investigated within $3 \mathrm{~km}$ of the Ozernaya River Delta (Fig. 21), situated beneath prominent gravel-capped beaches and terraces with upper surfaces at $35 \mathrm{~m}, 27$, and $12 \mathrm{~m}$ a.s.1. The highest site, Delta-3 (D-3), lies on the seaward flank of a $100 \mathrm{~m}$ broad beach where several $1 \mathrm{~m}$ deep stream channels dissect the crest of the regionally extensive $35 \mathrm{~m}$ a.s.l. shoreline. No apparent tilting of this shoreline was observed between the Changeable Lake and Ozernaya River field sites, a span of $25 \mathrm{~km}$, thus implying a $\sim \mathrm{W}-\mathrm{E}$ isobase direction. Lying a few metres below the elevation of the D-3 beach crest and less than a $\mathrm{km}$ distant are several distinct marine terraces on both sides of the river. A north-south trending tombolo-like morphological feature connects two of the terraces on the west side of the river, the best exposure revealed at site D-1. Still lower and closer to the present delta is another distinct marine terrace at $12 \mathrm{~m}$ a.s.l., the upper few metres of this terrace exposed at site D-2. The shape of its terrace mimics an even lower surface at $2 \mathrm{ma}$ a.s.l. and the coastline of the adjacent lagoon; both surfaces have a deltaic-like shape (Fig. 21).

Description-The beach crest section at D-3 (Fig. 22) predominantly consists of a few metres of medium-tocoarse, planar parallel-laminated sands with near horizontal to slightly dipping beds (up to $8^{\circ}$ toward the sea). Occasional outsized clasts $(1-3 \mathrm{~cm})$ occur throughout but are more common in the upper $0.5 \mathrm{~m}$. The sand is interbedded with several $1-5 \mathrm{~cm}$ thick massive silt layers and lenses. Mollusc shells are particularly common in the uppermost $50 \mathrm{~cm}$ of the section, mostly consisting of in situ Mya truncata. Delicate paired shells of other taxa including Hiatella arctica, Astarte, and Portlandia lie on the surface of eroded sand nearby. 

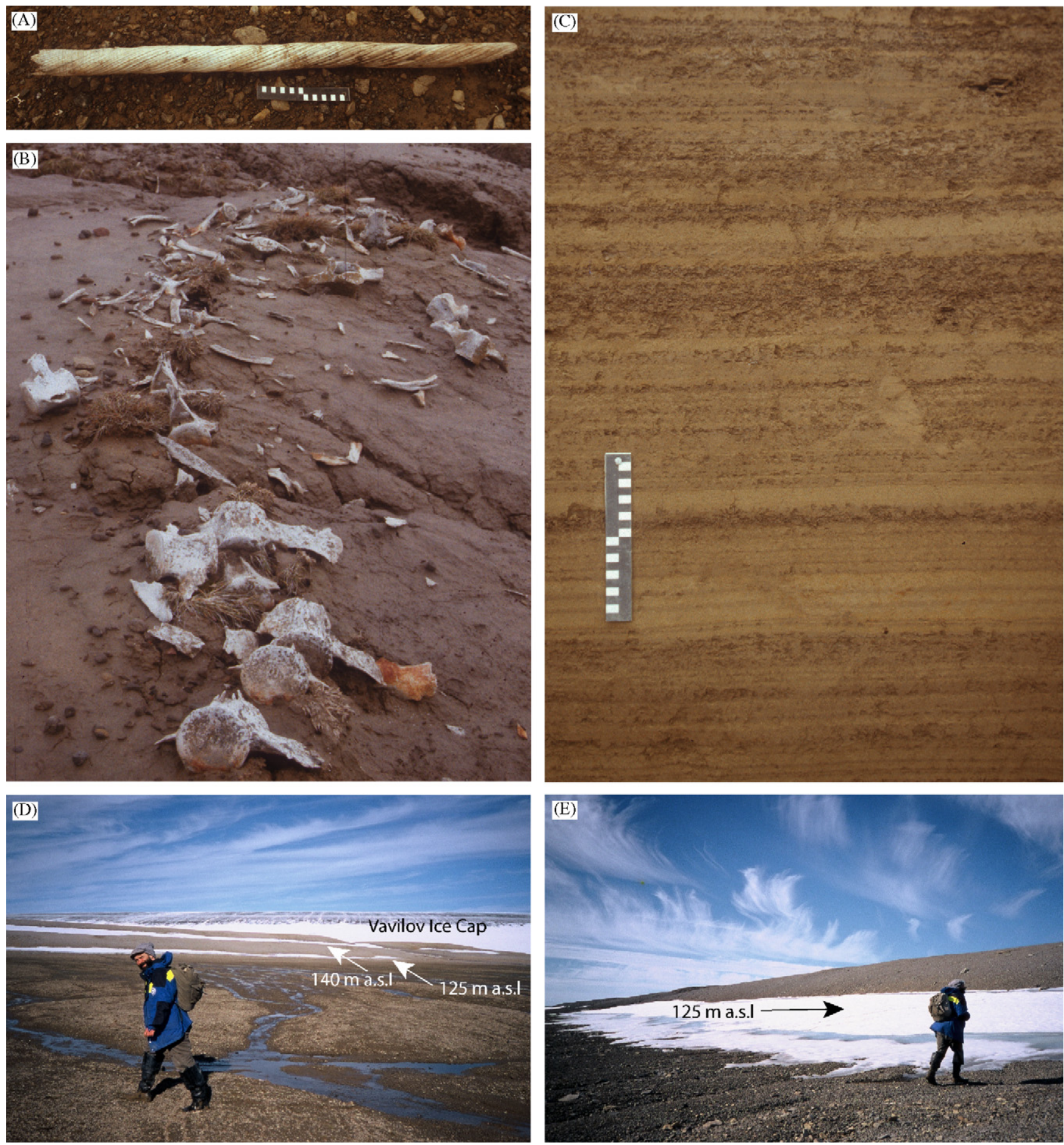

Fig. 17. (A) Narwhal tusk and (B) one of the near-to complete narwhal skeletons, eroding out of the silt deposits at site Oz 4. (C) Rhythmically laminated silts and clays at site $\mathrm{Oz} 4$, interpreted as a lagoonal deposit. (D) Two prominent marine escarpments highlighted by snow banks (arrows) with bases at $125 \mathrm{~m}$ and $140 \mathrm{~m}$ a.s.l. (for location, see Fig. 5). (E) The base of the $125 \mathrm{~m}$ a.s.l. marine escarpment close to Vavilov Ice Cap.

Sediment sections at sites D-1 and D-2 (Fig. 22) both show coarsening upwards successions. The lower half of each section is composed of massive silts and clays intrabedded with thin sand lenses $(1-2 \mathrm{~cm})$ that occur about 3-5 times per metre. In situ mollusc shells appear occasionally, with Portlandia present at both sites. Mya truncata and Astarte are also present at D-1. Erosional contacts at both sites mark transitions to coarser sediments, with the transition being particularly abrupt at the lower elevation D-2 site. Here, the upper half of the section consists entirely of laminated sand/gravel and massive gravel. The transition at D-1 is more variable with a combination of trough cross-laminated sands, massive silts, parallel-laminated sands, and other deposits eventually yielding to an uppermost section of parallel planar gravels and sands dipping $\sim 15^{\circ}$ to the southwest. Mollusc 


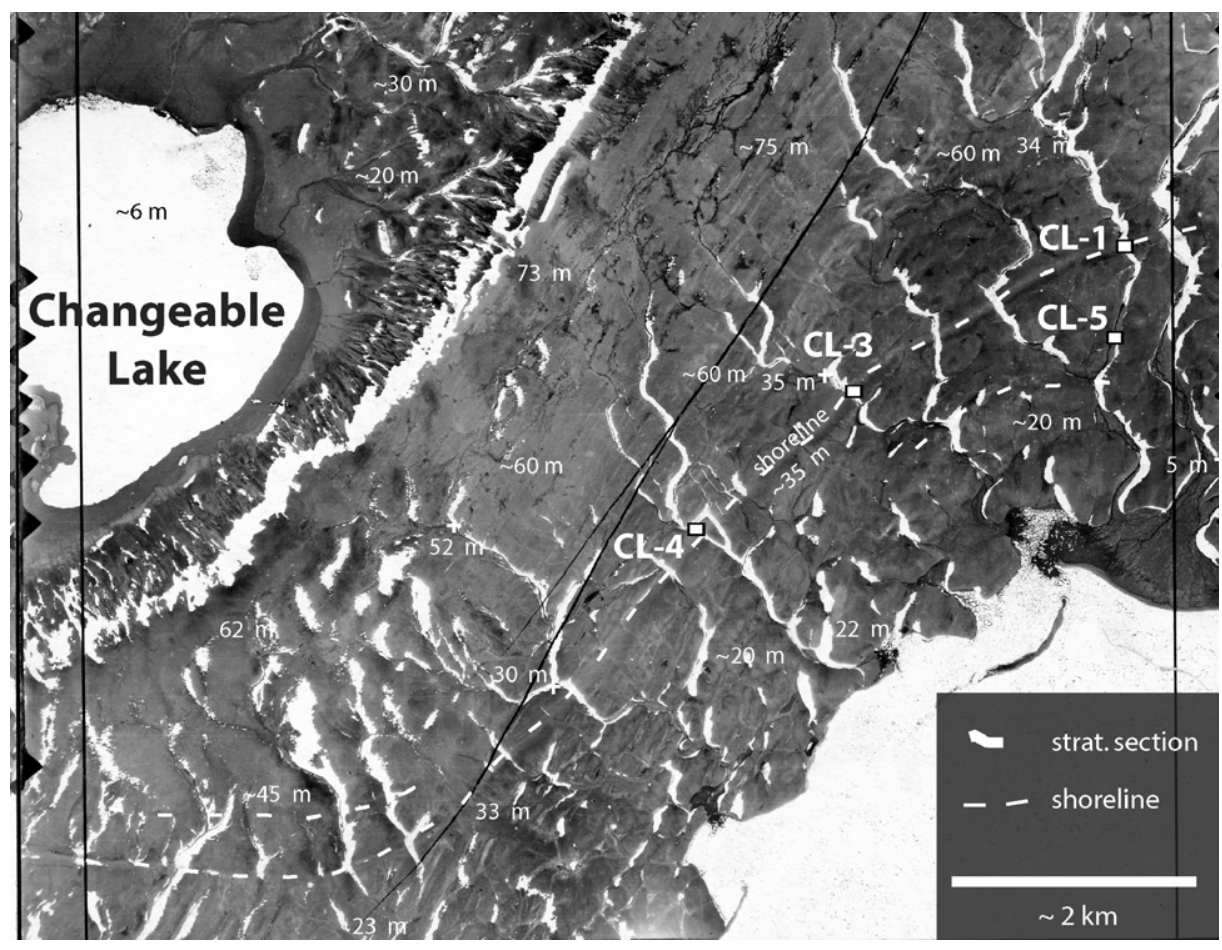

Fig. 18. Aerial photograph image of the Changeable Lake area. The $30-40 \mathrm{~m}$ a.s.l. raised shoreline forms a continuous and prominent feature in the landscape. Sampling localities and studied stratigraphic sections (CL 1-5) are indicated.

shell fragments were observed in the coarser sediments at both sites.

Chronology-Four in situ marine mollusc shells from the three sites yielded a ${ }^{14} \mathrm{C}$ age span of $40.4-45.6 \mathrm{cal} \mathrm{ka} \mathrm{BP}$, and are considered minimum, but possibly finite ages. These results are similar to the eight mollusc ages for the Changeable Lake sections, but all are much older than the $28-21 \mathrm{ka}$ ages below $\sim 25 \mathrm{~m}$ a.s.l. previously reported by Bolshiyanov and Makeyev (1995). The latter ages are based on conventional analyses of large samples that were not leached heavily, and probably reflect contamination by $5-2 \%$ of modern carbon (Taylor, 1987, p. 117). ESR dating of two marine molluscs at D-3 and D-1 yielded ages of 29 and $32 \mathrm{kaBP}$, respectively. These ages appear to be too young by at least $10 \mathrm{ka}$. Aspartic acid (D/L Asp) dating of 24 mollusc shells from the three sites yielded Asp values of $0.12 \pm 0.02$ (Table 7; Fig. 9), also similar to the Changeable Lake sections. GSL dates have a large scatter. Relatively young GSL ages of $36 \mathrm{ka}$ and $49 \mathrm{kaBP}$ were obtained from the D-3 sands and coarse upper deposits at D-2, respectively and are consistent with finite ${ }^{14} \mathrm{C}$ ages. In contrast, relatively old GSL ages of 129, 144, and $153 \mathrm{ka} \mathrm{BP}$ were obtained from the lower silts of D-2 and both the lower silts and upper sands of D-1, potentially indicating older depositional events. The GSL scatter is not likely to be representative of depositional ages given that the other three dating methods all suggest that raised marine sediments at the three Ozernaya River Delta sites are similar in age. The older GSL ages may reflect incomplete re-setting of the GSL signal (inheritance) with high suspended-sediment concentrations and rapid deposition at a delta front. We assign an age of ca 50 cal ka to these deposits, approximately equal to the oldest ${ }^{14} \mathrm{C}$ and youngest GSL ages on littoral facies obtained.

Interpretation - The laminated sands at the D-3 site combined with their beach crest morphology and in situ molluscs demonstrate a beachface environment. The D-1 and D-2 sites, with their transitions from massive marine silts and clays to uppermost gravel terraces, have a more complex environmental history. The lower fine-grained and fossiliferous portions of their sequences probably reflect offshore marine conditions, with interbedded sands representing storm events. At sites D-1 and D-2, the fine-grained sediments may also reflect former riverine input onto the deeper flanks of a delta system. The upward change across an erosional contact into laminated sands followed by laminated or clast-supported gravels suggests a sharp transition to a foreshore/beachface environment with sealevel regression. The Ozernaya Delta and correlative Changeable Lake sites reflect a regression from a marine limit of at least $40 \mathrm{~m}$ a.s.l. due to a single glacio-isostatic event at ca $45 \mathrm{cal} \mathrm{ka}$ or slightly older.

\section{Between-site correlations, event stratigraphy and chronology}

The stratigraphy of southern October Revolution Island (as summarized in Figs. 7 and 24) shows at least four cycles of glacial isostatic compensation, coupled to marine inundations with deglaciation. There is no evidence of 


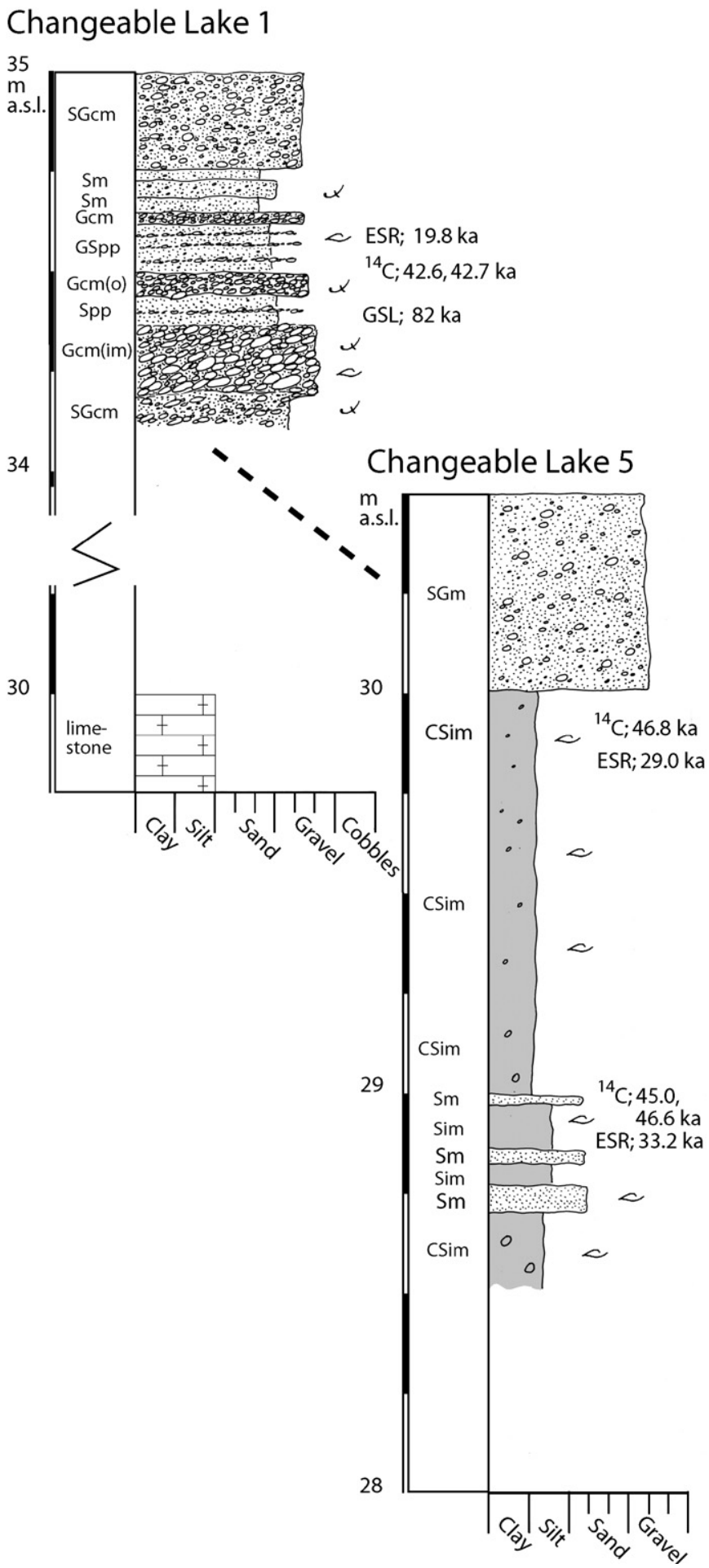

Fig. 19. Stratigraphic logs for the Changeable Lake sites 1 and 5 (CL 1 and CL 5; Fig. 18 for location).

stratigraphic repetitions due to glaciotectonic thrusting of the same till/marine units on top of each other, which have been shown from a number of localities in the Russian arctic/subarctic (e.g. Astakhov, 2001, 2004a), confusing the lithostratigraphy.

The Marine units I-IV in our field areas are sedimentologically distinct and yield statistically unique absolute $\left({ }^{14} \mathrm{C}\right.$, ESR and GSL; Fig. 23) and relative ages (D/L Asp ratios; Fig. 9) in nearly all cases. There are systematic differences between dating methods with ESR consistently yielding younger ages than ${ }^{14} \mathrm{C}$ and GSL. For example, the youngest shells from the Changeable Lake and Delta areas (M-IV) yield ESR ages of ca 20-30 ka (Table 5) versus finite ${ }^{14} \mathrm{C}$ ages of ca $40-46 \mathrm{ka}$ (Table 3 ) and young GSL ages on enclosing sediment of ca 36-49 ka (Table 5). ESR ages are also systematically younger than GSL ages for M-III sediments lower in the sequence (Table 5; Fig. 8B). The reason for this apparent underestimate of ESR ages relative to ${ }^{14} \mathrm{C}$ and GSL is unknown, but there is documented variability in the accuracy of ESR dating of molluscs that appears to be species dependent (e.g. Brumby and Yoshida, 1994; Schellmann and Radtke, 1997). In contrast, prior research on GSL in high Arctic near-shore environments (e.g. Forman, 1999) shows that this method yields close, but possibly overestimates. The latter are caused by insufficient solar resetting, which appears to be the cause for several GSL samples from the Delta areas yielding ages much older than ${ }^{14} \mathrm{C}(129-153 \mathrm{ka}$, Fig. 23). We thus report an age envelope for each unit based on using ESR ages as minimum estimates and GSL ages as close, but possibly overestimates.

The first glacial/deglacial cycle-T-I/M-I-forms the base of the $\mathrm{Oz} 1$ site and encompasses a basal till covered by marine deltaic and lagoonal deposits. The ESR and GSL ages, and the highest determined $\mathrm{D} / \mathrm{L}$ Asp ratios distinguish the M-I unit from the others, indicating a glacial phase that is pre-MIS 6, possibly MIS 10 in age, followed by deglacial high-stand marine levels (>70 ma.s.1.) at the MIS 10/9 transition (ESR age envelope 269-363 ka BP). Due to dating uncertainties however, it cannot be ruled out that it represents an even earlier (MIS 12/11) glacial/deglacial cycle (ESR age envelope 400-492 ka BP).

The second glacial cycle, T-II/M-II, shows extensive glacial deformation of M-I sediments followed by till deposition and then upon deglaciation deep-water glaciomarine sedimentation grading into a marine facies and subsequent shallowing. This deglacial hemicycle probably also occurred prior to MIS 6 according to GSL and ESR ages. As the ESR ages of ca $220 \mathrm{ka}$ are minimums, this deglacial event may correspond to the transition from MIS 8 to 7 with deglacial relative high sea level stand at $>71 \mathrm{~m}$ a.s.l.

The third glacial/deglacial cycle, T-III/M-III (Oz-1b and -1d), encompass a thick unit of deformation till, followed by a regressional sequence initiating with off-shore glaciomarine-marine sediments and capped by shoreface to foreshore sands and gravels. The M-III unit at $\mathrm{Oz} 1$ is correlated with the sediment sequences at the $\mathrm{Oz} 2$ and 3 sites. All have similar facies succession and ESR and D/L Asp age envelopes. The high-elevation shoreline sites, 125-140 m a.s.l., are correlative to M-III, thus evidently overrun by a regional-scale ice sheet but not here covered by Till unit IV as is the case at the $\mathrm{Oz} 1$ site. 
(A)
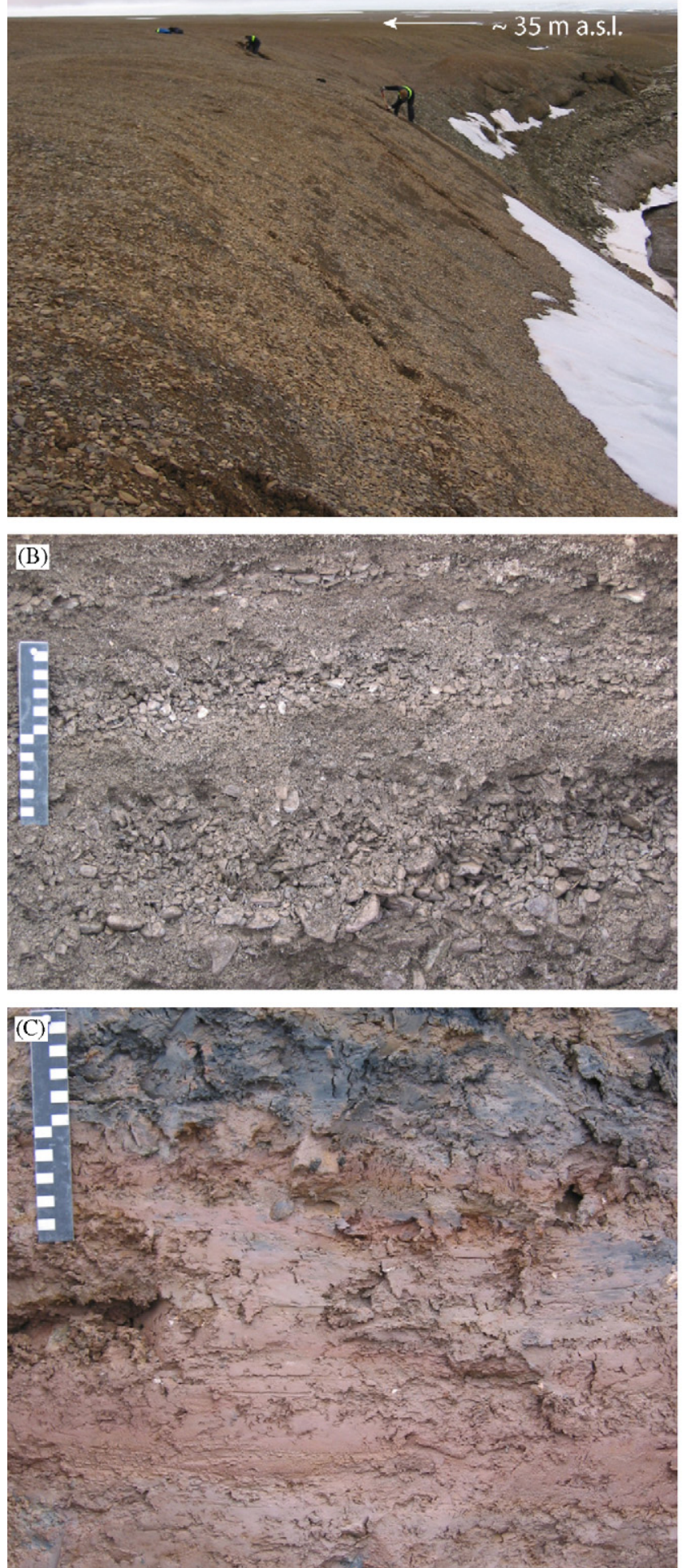
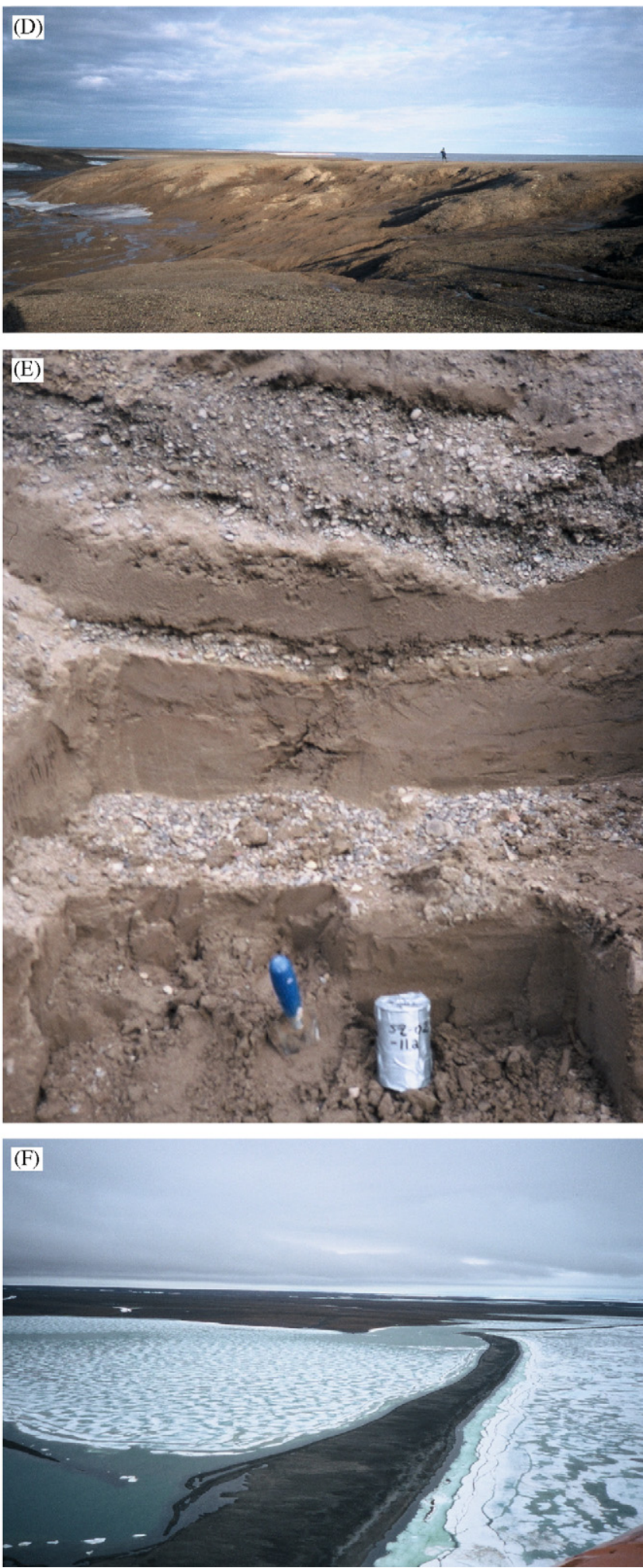

Fig. 20. (A) Broad beach terrace at site CL 1 (for location, see Fig. 18), cut by one of large number of meltwater streams, emanating from the Vavilov Ice Cap (seen in the distant background). This terrace, situated at 30-40 ma.s.l., is part of the most prominent raised shoreline encountered on S. October Revolution Island. (B) Open-work gravels interbedded with massive gravelly sand in the topmost part of the beach section at site CL 1 (Fig. 22 for sedimentary log). (C) Massive clay, interbedded with thin sand beds at site CL 5 with a rich fossil mollusc fauna (Fig. 19 for sedimentary log). (D) Overview of Delta-2 site (see Fig. 18 for location). Upper surface at $12 \mathrm{~m}$ a.s.l. Site later heavily excavated. (E) Gravel and sands in the upper portion of the Delta-1 section (Fig. 22). Sand sample SZ02-11a was collected for OSL dating at the height of base of can. (F) One of many spits along the southern shore of October Revolution Island. Ocean to the right. 


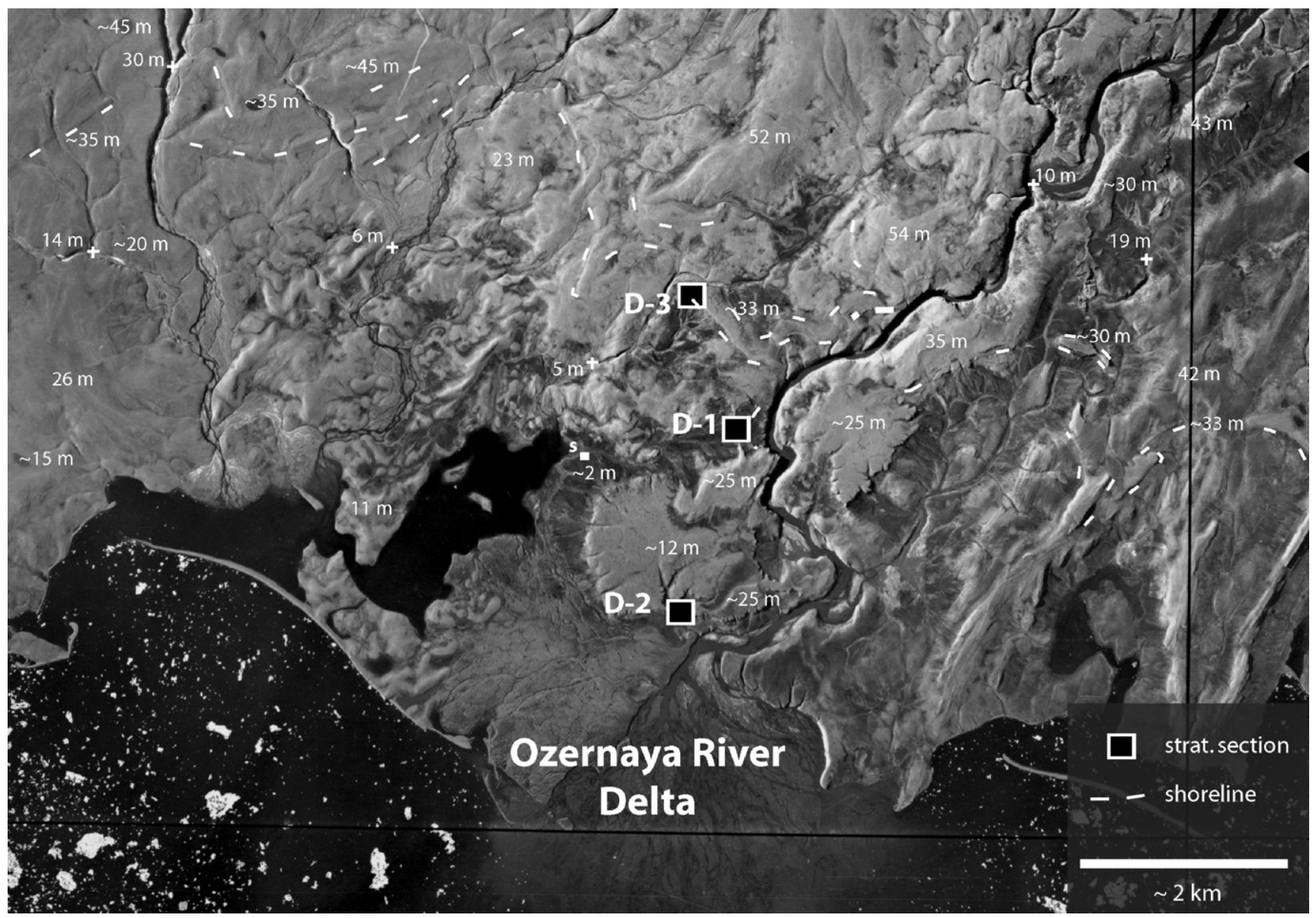

Fig. 21. Aerial photograph image of the lower part of the Ozernaya river valley, showing raised beach features, sampling localities and studied stratigraphic sections.

The preservation of old beach features on October Revolution Island is spectacular but not unique; such ones suggested to have been overrun by later glaciations have also been described from, e.g., Svalbard (Mangerud et al., 1992) and Ellesmere Islands (England, 1999). Two viable age options are at hand for the T-III/M-III cycle. The mean ESR age of $89 \mathrm{ka}$ BP (age envelope 77-105 ka) indicates an Early Weichselian stadial/interstadial transition, most probably MIS 5d/5c (Lambeck and Chappell, 2001). In contrast, the mean GSL age of $160 \mathrm{ka} \mathrm{BP}$ (age envelope 143-176 ka BP) suggests a Saalian to Eemian (MIS 6/5e) transition for M-III sediments and thus concordantly a Saalian age for T-III (MIS 6). Palaeontological data from M-III sediments show several subarcticboreal warmer-than-present indicators (Buccinum undatum and Balanus crenatus, Polydoria ciliata burrows on shell surfaces). According to Funder et al. (2002) a boreal-subarctic biogeographical zone extended through the Barents and the Kara Seas to Taymyr during the Eemian, as opposed to present-day arctic conditions, which support an Eemian age of this unit. Although nearly all of the foraminifera are arctic species, a few specimens of Trifarina cf. angulosa (see above) imply occasional input of Atlantic water deeply into the Kara Sea. Another potential age indicator is the co-occurrence of the foraminifera Elphidium ustulatum and Islandiella inflata, which are only rarely encountered in deposits younger than the Eemian in NW Europe. We favour an Eemian age for M-III, partly based on the palaeontological indicators and, more importantly, results of comparisons between dating methods for M-IV sediments (see below).

Offering additional support for an Eemian age assignment for M-III are results from site 101 in the Changeable Lake watershed ( $\sim 30 \mathrm{~m}$ a.s.1.), described by Bolshiyanov and Makeyev (1995) (Fig. 3). Here a short section of silt contains a foraminiferal fauna resembling that of our

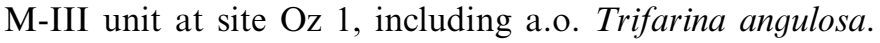
Even more important is that the sediments host the mollusc Chlamus islandicus, a subarctic, but for Severnaya Zemlya a real warmer-than-present indicator, yielding ESR ages of $105 \pm 11$ and $120 \pm 13 \mathrm{ka}$ BP (Bolshiyanov and Makeyev, 1995). Strengthened by this correlation, we place the Marine III unit in the late MIS 6 and early MIS 5e (Eemian), and based on the foraminifera, we place the MIS $6 / 5$ e boundary (Termination 2) at the faunal shift between 79.5 and $80.0 \mathrm{~m}$ a.s.1. in the lower part of Oz-1d (Fig. 12). A consequence of this age assignment is that T-III is Saalian in age (MIS 6) and that T-IV is Weichselian in age. 


\section{Ozernaya River Delta 1}

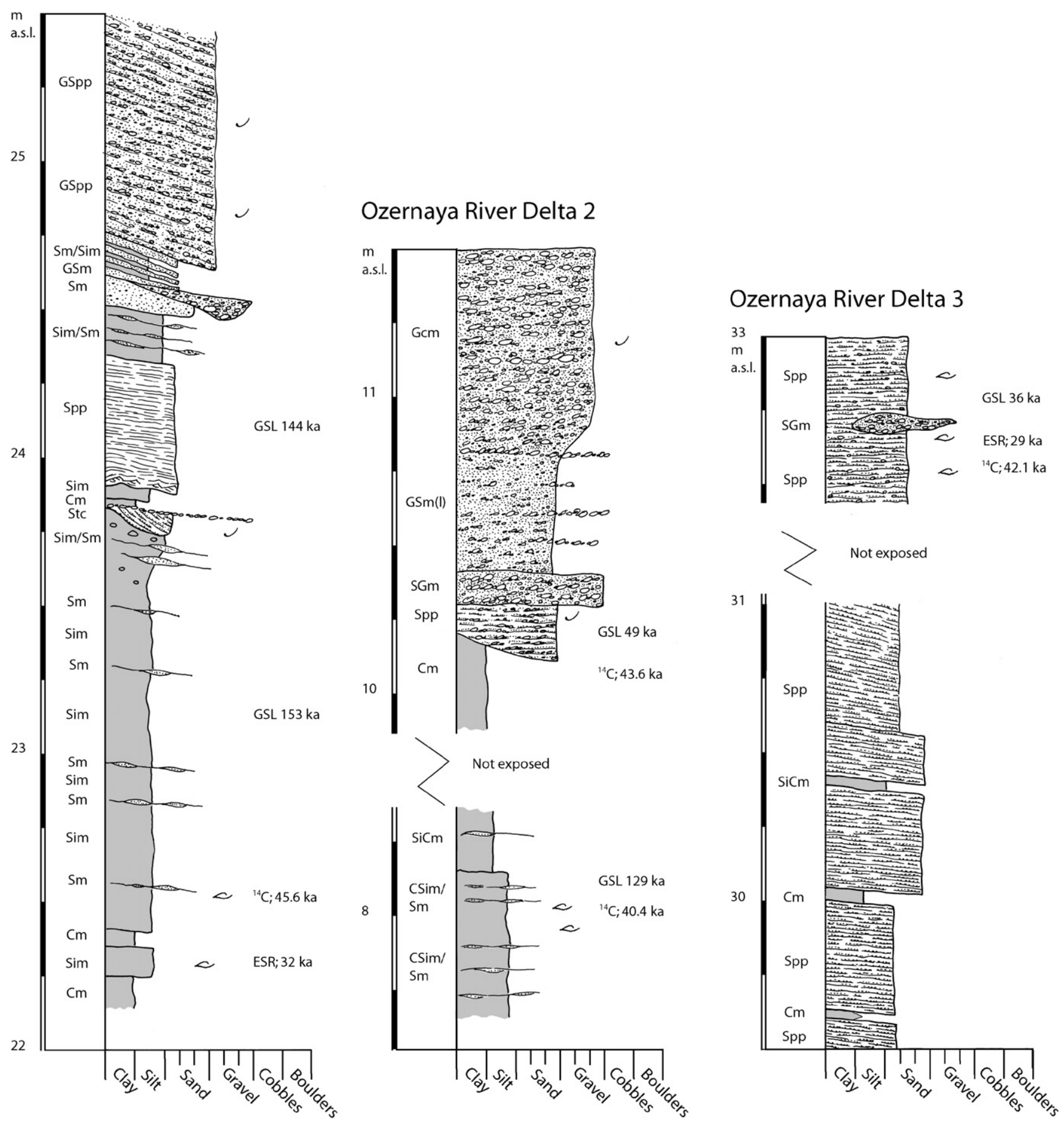

Fig. 22. Stratigraphic logs for the Ozernaya River Delta sites (D-1, D-2 and D-3; Fig. 21 for location).

The sediment successions in the Changeable Lake $(\mathrm{CL}$ 1-CL 5; Fig. 18) and in the Ozernaya River Delta areas $(\mathrm{Oz}$ RD 1-3; Fig. 21) are correlative and reflect a regression from a marine limit of at least $40 \mathrm{~m}$ a.s.l., marked by the highest extent of the prominent shoreline physically connecting the areas (Fig. 4B). Both areas have similar, coarsening-upwards sediment successions from off-shore marine muds to foreshore/shoreface sands and gravels, consistently with low $\mathrm{D} / \mathrm{L}$ Asp ratios on molluscs, and finite ${ }^{14} \mathrm{C}$ ages of $36.6-46.8 \mathrm{cal} \mathrm{ka} \mathrm{BP}$, which are finite but close to the analytical limit. The GSL ages of ca $40-50 \mathrm{ka}$ on littoral facies support the finite ${ }^{14} \mathrm{C}$ ages whereas GSL ages from the lower parts of these successions are significantly older (82-153 ka). However, mollusc shells here give the same low $\mathrm{D} / \mathrm{L}$ Asp ratios as those higher up in the successions (Table 7; Fig. 9) with considerably younger 


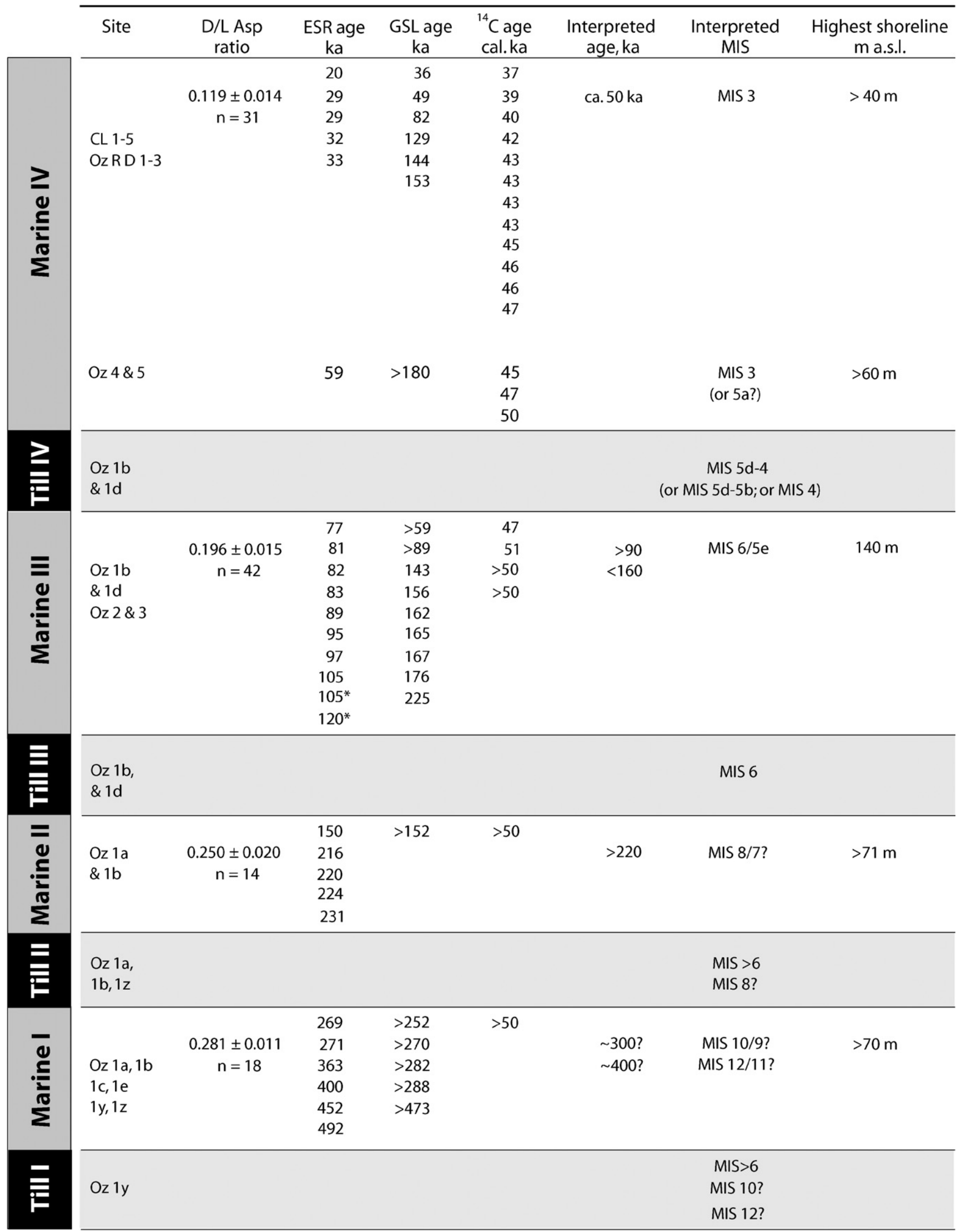

Fig. 23. Summary of geochronological data for October Revolution Island (Tables 3-6; ESR ages marked * are from Bolshiyanov and Makeyev, 1995). 


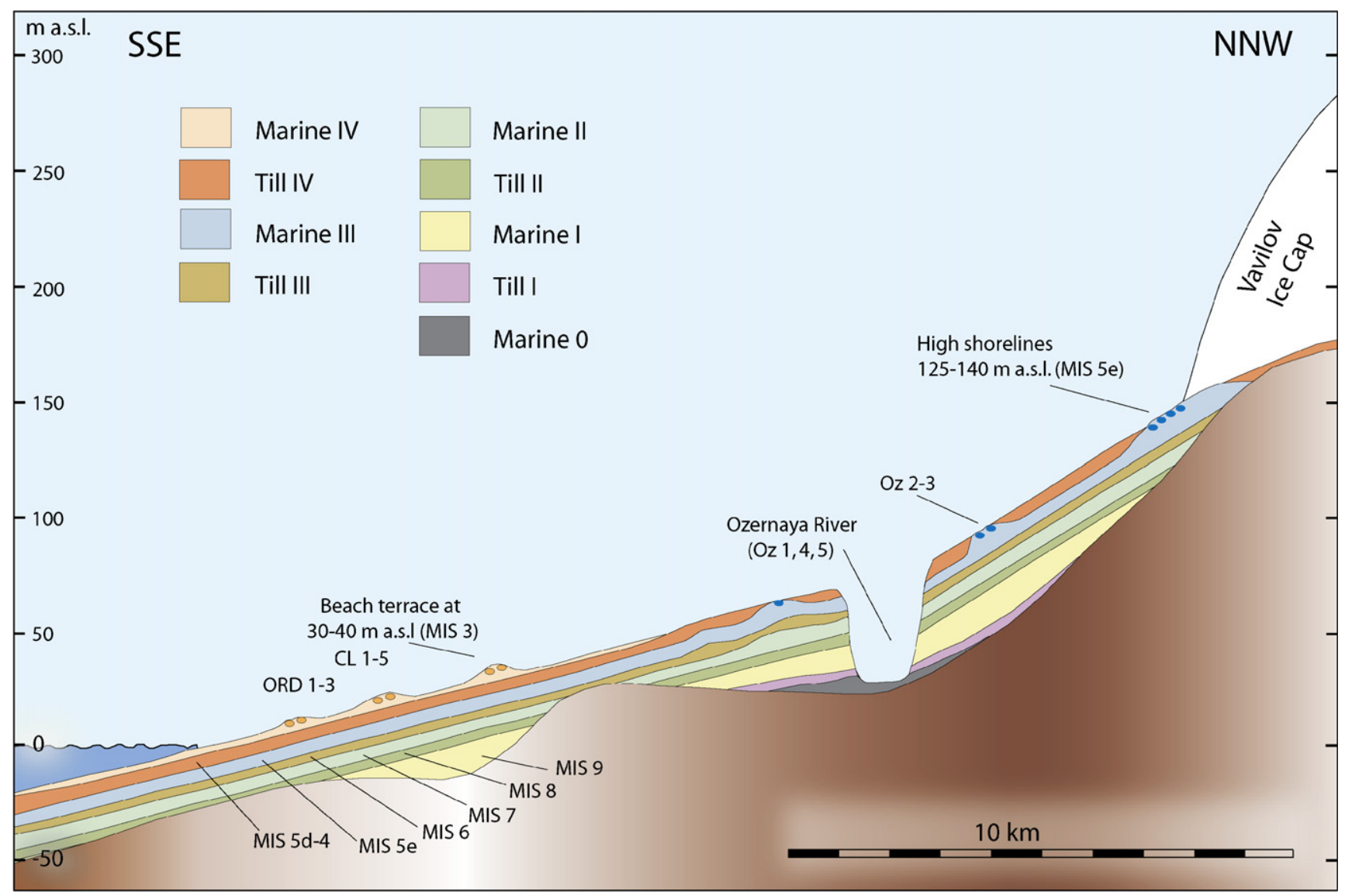

Fig. 24. Generalized stratigraphy for southern October Revolution Island showing the inferred relation between identified tills, marine sediments and beach deposits, and their tentative chronology.

GSL dates; it is hence suggested that these older GSL ages reflect insufficient solar resetting of sediment particles at transport/deposition and thus yield overestimates. In summary, we assign an age of ca 50 cal ka BP (MIS 3) for these sediment successions, thus being our youngest marine unit, labelled Marine unit IV.

The lagoonal sediments at sites $\mathrm{Oz} 4$ and $\mathrm{Oz} 5$ are probably correlative with M-IV, but an older age assignment is possible given limited chronologic control and inability to physically correlate to other deposits. However, the foraminiferal composition is different from the Marine units I-III, e.g. in the absence of Islandiella inflata and Elphidium ustulatum that are otherwise present in all other marine units, indicating that the $\mathrm{Oz} 4$ and 5 marine sediments may not be correlative to any of these marine units. The most compelling age control is a $\mathrm{D} / \mathrm{L}$ asp ratio from Oz $5(n=4)$ with a similarly low value as Changeable Lake and the Ozernaya River Delta localities (Table 7). In contrast, a single ESR age of $59 \mathrm{ka} \mathrm{BP}$, interpreted as minimum, is approximately twice as old as at those localities. ${ }^{14} \mathrm{C}$ ages at $\mathrm{Oz} 4$ (45 and $47 \mathrm{cal} \mathrm{ka}$ ) and $\mathrm{Oz} 5$ (interpreted as $>50 \mathrm{ka}$ ) are ambiguous; they are consistent with those localities as well as the ESR age because of their close proximity to the ${ }^{14} \mathrm{C}$ analytical limit. Thus, we assign an age of MIS 3 to the $\mathrm{Oz} 4$ and $\mathrm{Oz} 5$ sediments, but cannot exclude the possibility that they are associated with an older marine event following an Early Weichselian deglaciation (MIS 5b/5a?).

With M-III in the Eemian and M-IV at the Changeable Lake and the Ozernaya River Delta successions in the Middle Weichselian (MIS 3), what is the stratigraphic position and age of T-IV? T-IV lies on top of M-III at site $\mathrm{Oz} 1$ but it has not been observed to be intercalated between M-III and M-IV in a continuous stratigraphic sequence. The simplest explanation is that the intercalation exists but has simply not yet been found, and that Severnaya Zemlya was covered by an ice sheet of varying size for much or all of MIS 5d to MIS 4, with emplacement of T-IV followed by deglaciation and deposition of M-IV at the MIS $4 / 3$ transition. The age of T-IV is poorly constrained, however, and we cannot rule out the possibility that it may be linked to an earlier glacial-deglacial cycle (5b/5a?), possibly associated with the $\mathrm{Oz} 4$ and $\mathrm{Oz}$ 5 marine sediments. This scenario, which we consider less likely, would imply deglaciation of Severnaya Zemlya in MIS 5a followed by a re-glaciation in MIS 4 (Fig. 24).

\section{Regional correlations}

The literature on the Quaternary stratigraphy of the West Siberian Plain and the Taymyr Peninsula is vast, but comprehensive summaries and critical reviews are now 

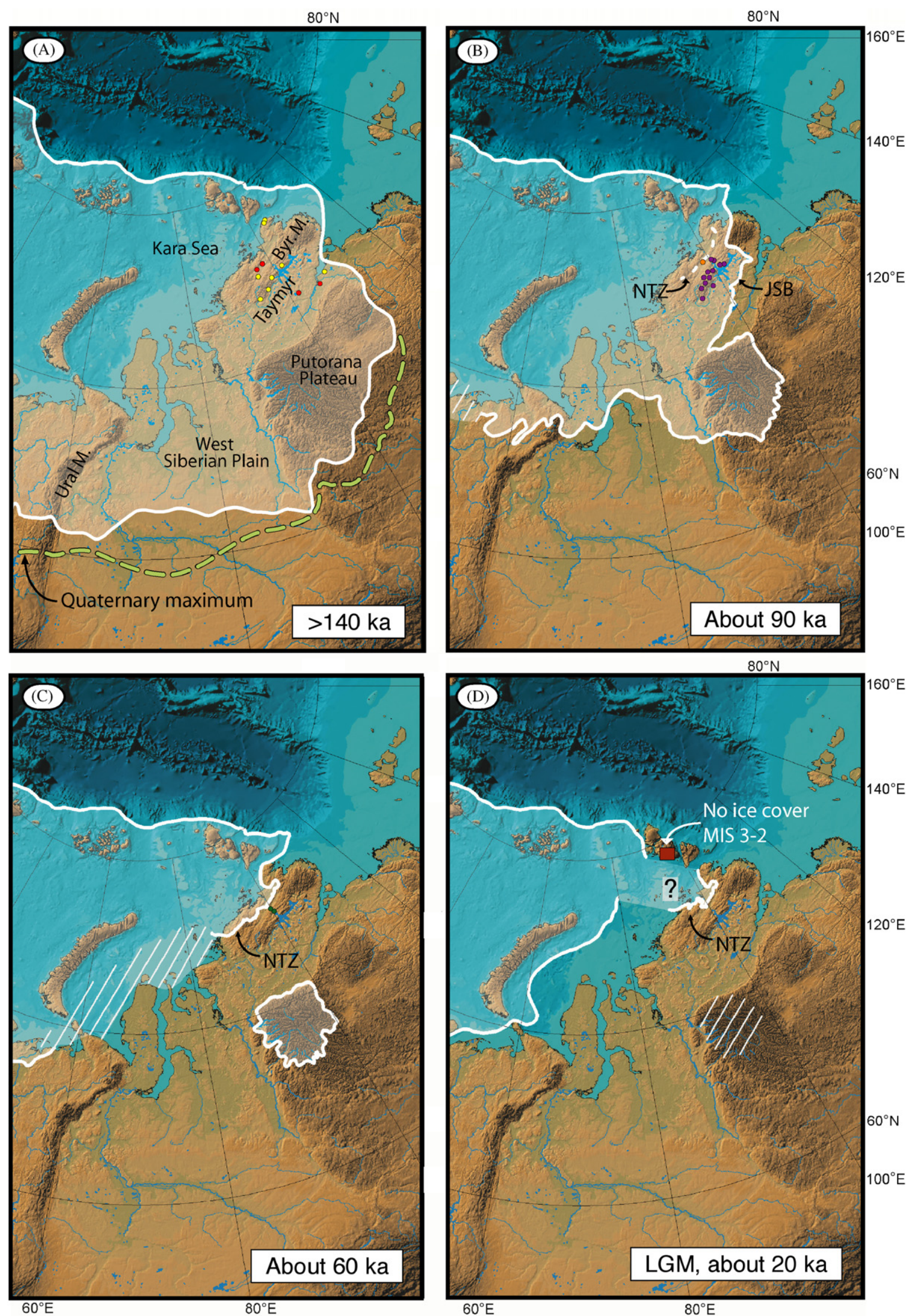
available as part of the QUEEN programme (Astakhov, 2001, 2004a, b). In all regions three to five diamict sheets are found interbedded with interglacial or interstadial deposits. The latter are preferentially stratified terrestrial deposits in the subarctic areas closer to the maximum drift boundary (Fig. 25A) and marine deposits in the arctic areas within and just outside the more restricted maximum boundary of the Late Pleistocene glaciations (Fig. 25B) (Astakhov, 2004a). However, this stratigraphy is rarely observed in stratigraphic superposition but constructed from borehole correlations; thus the Ozernay River sections are unique for Arctic Russia with at least three marine units intercalated with tills in superposition. The Kazantzevo marine beds with an arctic-boreal mollusc and foraminiferal fauna, correlated with the Eemian sediments of the Boreal transgression in European Russia (MIS 5e), are an important stratigraphical marker for western Siberia. However, some supposedly Kazantzevo-aged marine strata also contain shells extinct species as Cyrtodaria augusta (Kind and Leonov, 1982), indicating that these sediments belong to an earlier interglacial, possibly the Tobol interglacial (Astakhov 2004a; Svendsen et al., 2004), and thus reducing the usefulness of marine strata with boreal-arctic faunas as a stratigraphic key horizon. The till lying immediately below the Kazantzevo deposits on southern Taymyr belongs to the Murukta glaciation (Kind and Leonov, 1982), which is correlated to the Taz glaciation of western Siberia (Arkhipov et al., 1986; Arkhipov, 1989) and regarded as Late Saalian in age (MIS 6). The largest ice sheet expansion is tied to the Middle Pleistocene Samarovo glaciation (MIS 8), forming the maximum glacial drift boundary in western Siberia (Fig. 25B) and overlying the Tobol interglacial strata (Astakhov, 2004b). However, the age of the Tobol strata is poorly constrained; a number of ESR and TL ages cluster at ca 300 ka BP (Arkhipov, 1989), suggesting a MIS 9 age, but also older ESR and TL ages at ca $390 \mathrm{ka}$ BP have been retrieved (Volkova and Babushkin, 2000; as cited in Astakhov, 2004a), suggesting a MIS 11 age. This is correlative to the Holsteinian, which seems to be the preferred interpretation (Astakhov, 2004b) as the palaeontological proxies indicate a full interglacial climate at deposition of the Tobol beds. Even older, pre-Holstein glaciations are recognized as the Shaitan glaciation (MIS 12-16) and the Mansi glaciation (MIS 18) (Arkhipov, 1989), but all with more limited extensions than the aforementioned Samarovo glaciation.
Marine successions below at least one till and yielding ESR ages compatible to those for Marine unit I in the Ozernaya River sections have been reported from a few localities on the Taymyr Peninsula (Fig. 25A, red dots; Bolshiyanov and Molodkov, 1998). Molluses in marine sediments from the Shrenk and Mamonta River valleys north of the Byrranga Mountains yield ESR ages of 332 and $268 \mathrm{ka} \mathrm{BP}$. From south of the Byrranga Mountains, marine sediments at Labaz Lake yield a set of ESR ages between 274 and $320 \mathrm{ka} \mathrm{BP}$ and at the Novorybnoe Village, along the Khatanga River $(750 \mathrm{~km}$ SSE of October Revolution Island; Fig. 25A), a lower marine succession has an ESR age of $336 \mathrm{ka} \mathrm{BP}$. All these dates conform to the ESR ages given for the Tobol interglacial in Astakhov (2004a), thus indicating wide-spread marine conditions over NW Siberia, presumably during the MIS 10/9 transition, and T-I at Ozernaya River could then possibly correlate to the Shaitan glaciation (MIS 10).

The stratigraphic record from the Taymyr Peninsula have yet to yield any marine sediments with ages compatible to those of M-II of Ozernaya River (i.e. $220 \mathrm{ka} \mathrm{BP})$. However, Molodkov and Bolikhovskaya (2002) report an ESR age cluster of about $220 \mathrm{ka}$ on high sea-level stand, raised marine deposits for northern Eurasia. The ESR age envelope for M-II might possibly fit into the Shirta interglacial (MIS 7), as dated on the NW Siberian Plain (Astakhov, 2004a), but interglacial sediments with rich organic remains, sandwiched between Taz and Samarovo tills, are rarely encountered (Volkova and Babushkin, 2000; as cited in Astakhov, 2004a).

The Ozernaya River M-III is correlated to the Kazantzevo/Eemian marine deposits described from a large number of sites on the Taymyr Peninsula south of the Byrranga Mountains (Urvantsev, 1931; Saks, 1953; Kind and Leonov, 1982). The sediments here range from deepermarine deposits on low altitudes to shallow-water sediments close to $130 \mathrm{~m}$ a.s.l. These sediments are often tillcovered proximal to the reconstructed Early Weichselian ice sheet maximum (Fig. 25B; Fisher et al., 1990; Svendsen et al., 2004) and then, further south, not till-covered but draping Murukta/Taz/Saalian till, the latter correlated with our T-III on October Revolution Island. Typical ESR ages reported for Kazantzevo/Eemian marine sediments from south of the Byrranga Mountains (Molodkov and Bolikhovskaya, 2002) range from 111 to $140 \mathrm{ka} \mathrm{BP}$ (120 ka BP mean for eight ages), whereas Eemian beachface to foreshore sediments from the Cape Chelyuskin area

Fig. 25. QUEEN reconstructions of ice sheet extent over the eastern Eurasian Arctic, rearranged from Svendsen et al. (2004). (A) The Late Saalian and the Quaternary maximum ice-sheet extent. Red dots are ESR-dated sites on Taymyr Peninsula with presumably Tobol interglacial marine sediments (MIS 9?) (Bolshiyanov and Molodkov, 1998). Yellow dots within and south of the Byrranga Mountains are ESR-dated sites with Kazantzevo/Eemian marine sediments according to Bolshiyanov and Molodkov (1998), whereas those in the north are ESR and OSL-dated Eemian marine sediments in the Cape Chelyuskin area (Hjort et al., 2004). (B) The Early Weichselian maximum ice-sheet extent. Violet dots are ESR and OSL-dated sites with marine/marine deltaic sediments deposited during ice recession toward the Byrranga Mountains; orange dot is site with OSL-dated glaciolacustrine deltaic sediments from ice-dammed lake in front of the North Taymyr ice-marginal Zone (Hjort et al., 2004). JSB = the Jangoda-Syntabu-Baikuronyora line, the EW maximum on Taymyr; NTZ = North Taymyr ice-marginal zone at EW deglaciation. (C) The Middle Weichselian maximum ice-sheet extent. Green dots are OSLdated sites with glaciolacustrine sediments within, and in out-flow areas from ice-dammed lake in front of the NTZ according to Hjort et al. (2004). (D) The Late Weichselian maximum ice-sheet extent. 


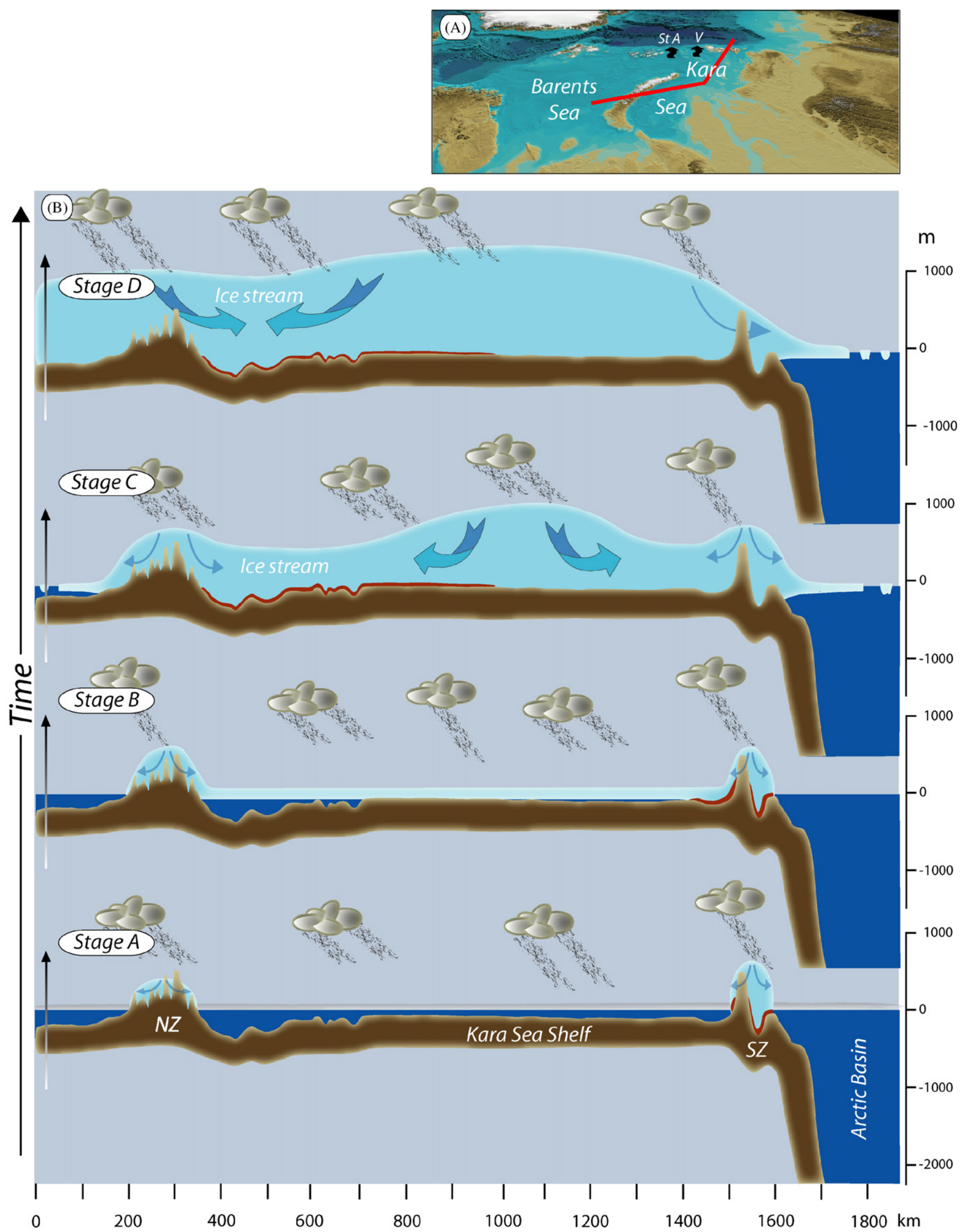


(Fig. 2), here sandwiched between two till units, give ESR ages between 111 and $156 \mathrm{ka}$ BP (131 ka BP mean for nine ages), supported by OSL ages of $100-110 \mathrm{ka} \mathrm{BP}$ on the same sediments (Svendsen et al., 2004; Möller et al., in prep).

Weichselian ice-sheet extent reconstructions of the QUEEN community (Astakhov, 1998; Svendsen et al., 2004; Hjort et al., 2004) suggest that the Weichselian maximum of a Kara Sea-based ice sheet (KSIS) in the south is demarcated by the Jangoda-Syntabul-Baikuronyora ridges, the JSB line, (Fig. 25B), a wide push moraine that can be followed for some $850 \mathrm{~km}$ (ca 90-100 ka BP; MIS 5b). Subsequent ice recession is associated with marine inundation south of the Byrranga mountains and deposition of marine sediments and deltas reaching $100 \mathrm{~m}$ a.s.l. along the southern Byrranga Mountains, the "Ledyanaya Gravel Event," dated to 95-70 ka BP (26 ESR ages and 5 OSL ages; Möller et al., 1999a, b; Hjort et al., 2004). The KSIS recession halted temporarily north of the Byrranga Mountains and constructed the complex North Taymyr ice-marginal Zone (NTZ, Fig. 25B) (Alexanderson et al., 2001, 2002). Simultaneously an ice-dammed lake was formed between the ice margin and the Byrranga Mountains with meltwater rerouting southwards along the Taymyr River valley, all dated by OSL ages of ca $80 \mathrm{ka}$ BP (Hjort et al., 2004). On the northern flank the KSIS seems to have expanded to the continental shelf margin also in the Early Weichselian, as indicated by IRD peaks in sediment cores retrieved off the shelf, interpreted to represent advance/retreat phases of the KSIS (Knies et al., 2001). The Kara Sea ice sheet re-advanced southwards to the NTZ at around 70-54 ka BP according to OSL ages (Alexanderson et al., 2001, 2002), i.e. in the Middle Weichselian (Fig. 25C), adding sediments to this complex marginal zone and depositing deltaic sediments in a reformed, lower-altitude ice-dammed lake. It is not known how far the KSIS retreated before this Middle Weichselian advance (Hjort et al., 2004, Fig. 7). Along the northern margin the KSIS advanced to the shelf break, as indicated by the largest IRD peak within Weichselian deep-sea mud, set at MIS 4 (Knies et al., 2001), and from a well-defined moraine ridge at $385 \mathrm{~m}$ water depth NE of Severnaya Zemlya, suggested to be Middle Weichselian in age (Niessen et al., 1997).

This regional glacial-stratigraphic assessment of above indicates glaciation of Severnaya Zemlya in the earliest part of the Early Weichselian (MIS 5d), building to a full KSIS ice sheet with its maximum margin at MIS 5b. Our preferred interpretation of the youngest part of the Severnaya Zemlya stratigraphy suggests glacier coverage until MIS 3 (ca 50-60 ka; Marine unit IV). Thus, Severnaya Zemlya probably supported glaciers throughout MIS 5 and served as a nucleation area for the re-growth and expansion of the KSIS to the northern shelf and the NTZ in the south during MIS 4. Such an ice remnant would probably be detached from any remaining ice of the Barents Sea Ice Sheet. The Till corresponding to the prolonged Severnaya Zemlya glaciation would thus be T-IV in the Ozernaya River sections. Till IV is also correlated to the diamicton deposited at the base of the sediment sequence recovered from Changeable Lake on October Revolution Island, having a minimum age constrained by ${ }^{14} \mathrm{C}$ ages of $>47$ and $>48 \mathrm{ka} \mathrm{BP}$ and one IRSL age of $53 \mathrm{ka} \mathrm{BP}$ on marine sediments immediately above the diamicton (Raab et al., 2003; Berger et al., 2004), which is compatible with the ages received for our M-IV.

Our studies indicate a clear lack of younger sedimentary successions and raised shoreline features on October Revolution Island that could be associated with a Late Weichselian (MIS 2) glacial/deglacial event. This is also

Fig. 26. A conceptual build-up model for a Kara Sea-based ice sheet based on ideas put forward by, e.g. Siegert et al. (2002). (A) 3D-view of the Arctic Ocean, courtesy Martin Jakobsson. Bathymetry is based on the International Bathymetric Chart of the Arctic Ocean (IBCAO) (Jakobsson et al., 2000). Vertical profiles in panel B, crossing Novaya Zemlya and the Severnaya Zemlya archipelago, is outlined with red line (western endpoint at $48^{\circ} \mathrm{E}$ and $72^{\circ} 30^{\prime} \mathrm{N}$, eastern end point at $122^{\circ} \mathrm{E}$ and $80^{\circ} 20^{\prime} \mathrm{N} ; 1800 \mathrm{~km}$ ). Black arrows mark the St. Anna (St A) and the Voronin Troughs (V). (B) Arbitrary chosen time-slices, stages A-D, of the gradual build-up of a Kara Sea-based ice sheet. Red line at ice/bed boundary on Severnaya Zemlya indicate wet-based conditions during inception phases of the KSIS, later transforming into cold-based conditions during full glacial conditions over the more highly situated KSIS nucleation areas.

Stage A: Local ice caps start to develop on islands within and along the perimeter of the shallow Kara Sea shelf, and also over, e.g., the Byrranga Mountains on the Taymyr Peninsula to the south. The local ice-caps were characterized by wet-based thermal regimes, producing basal tills in the stratigraphy. A pre-requisite for this is ice-cap build-up during a relatively mild climate, possibly starting during interglacial conditions(?), as frictional heating at the base would hardly overcome the very low built-in glacier surface temperatures at stadial conditions on these latitudes (Severnaya Zemlya ice caps are cold-based today). Later, perennial sea ice on the Kara Sea becomes fast ice, increasing the albedo and creating a positive feed-back loop increasing the snow accumulation and lowering of the snowline.

Stage B: Fast ice transforms into an ice shelf that thickens due to surface snow accumulation and basal freezing. Global ice sheet build-ups lead to globally falling sea level, reducing water depths over the shelf area.

Stage C: Shelf ice thickens, both due to surface accumulation and basal freezing, and gets grounded in the shallowest areas. A marine ice dome is formed which coalesces with the terrestrial ice caps, initiating redistribution of ice drainage patterns and basal thermal regimes.

Stage D: A fully developed Kara Sea Ice Sheet (KSIS) which drains towards the Arctic basin in the north, preferentially as ice streams developed along the Voronin and St. Anna troughs, but also drains towards the south, impinging on the Taymyr Peninsula and crossing the Byrranga Mountains. During full KSIS conditions, the stratigraphic information from Severnaya Zemlya suggests cold-based thermal regime over "inception islands," as no KSIS tills could be recognized. 
suggested from the freshness of the 30-40 $\mathrm{m}$ a.s.l. beach system, being the youngest encountered marine sediments (M-IV) never seen to be overlain till, as is the case for M-III sediments. Further, the young GSL ages of redeposited M-I sediment at the $\mathrm{Oz} 1$ site $(\mathrm{Oz}-1 \mathrm{e} / 15$, Table 6; 22 and $17 \mathrm{ka} \mathrm{BP})$ provide a minimum age for the onset of the erosional processes forming the heavily dissected Ozernaya 1 site and also indicate the dominance of non-glacial processes during LGM. Combined with reported ages on mammoth remains (Table 4) and the sediment succession in Changeable Lake, indicating continuous deposition since ca $53 \mathrm{ka} \mathrm{BP}$ (Raab et al., 2003), there is strong support for ice-free conditions over the Severnaya Zemlya archipelago during the LGM (MIS 2).

\section{Implications for KSIS build-up and dynamics}

Reconstructed ice sheet margins on the terrestrial NW Siberian plain (Fig. 25; Svendsen et al., 2004)) and IRD peaks in deep-marine muds off the continental shelf in the north (Knies et al., 2001; Spielhagen et al., 2004), all signify repeated build-up of thick ice sheets on the shallow shelves of the Barents and Kara Seas during the Middle and Late Quaternary. The substantial glacioisostatic loading from these continental-scale ice sheets are mirrored in high raised beaches, among the highest described from the Eurasian Arctic. Examples include the 130-140 ma.s.l. Saalian/Eemian-inundation shoreline on October Revolution Island, located just $200 \mathrm{~km}$ from the shelf break to the Arctic Ocean and a similar age Kazantzevo/Eemian shoreline at $130 \mathrm{~m}$ a.s.1. on the Taymyr lowlands, $\sim 300 \mathrm{~km}$ south of the present Kara Sea coast. Using such shoreline evidence and dated ice-marginal formations, the maximum KSIS thickness during the Saalian is estimated to $3000-3300 \mathrm{~m}$ by earth rheological inverse modelling (Lambeck et al., in press). The thick Saalian KSIS may have produced an ice shelf protruding into the Arctic Ocean that grounded over the Lomonosov Ridge at $1000 \mathrm{~m}$ of water depths (Jakobsson et al., 2001; Polyak et al., 2001).

Glacial geologic evidence from Severnaya Zemlya and several other areas along the perimeter of the shallow Kara Sea suggests that peripheral sites were critical for the initiation of a large Kara Sea ice sheet. Structural and textural evidence from tills and sub-till sediments in our Severnaya Zemlya stratigraphy imply deformation and deposition during expansion of local ice caps, with no evidence other than the raised beaches for expansion of thick Kara Sea-based ice sheets onto southern October Revolution Island. These observations suggest that initial KSIS growth occurred with formation of local ice caps, consistent with data from, e.g., the Taymyr Peninsula (Hjort et al., 2003; Möller et al., in prep), the Yugorski Peninsula (Lokrantz et al., 2003) and the western Yamal Peninsula (Forman et al., 1999, 2002). These local icecaps were characterized by wet-based thermal regimes, as suggested from basal tills and sub-till plastic deformational structures on Severnaya Zemlya. As local ice domes in highland areas and along the perimeter of the Kara Sea grew, they coalesced on the adjacent shelf with globally falling sea level, and large ice domes formed, initiating redistribution of ice drainage and basal thermal regimes. A fully developed KSIS drained preferentially towards the Arctic Ocean to the north as ice streams developed along, e.g., the Voronin and St. Anna Troughs, but also expanded southward, impinging on the Taymyr Peninsula and crossing the Byrranga Mountains. Stratigraphic data from Severnaya Zemlya suggests cold-based thermal regimes over "inception islands" during maximum ice sheet extent because there is a lack of tills associated with Kara Sea sources. A conceptual model for this KSIS build-up scenario is presented in Fig. 26. As well as lowered sea levels during glacial inceptions promoted ice-sheet build-up on the shallow Kara Sea shelf, we propose that shelf-based ice was broken down during world sea-level rise during glacial terminations.

\section{Conclusions}

On the basis of our field data and re-interpretation of previous studies of the Quaternary environmental history of Severnaya Zemlya we draw the following conclusions:

(i) Stratigraphical and morphological records on Severnaya Zemlya reveal a long and complex Middle to Late Pleistocene history of glaciations and associated sea level changes.

(ii) At least four distinct sedimentologic, morphologic and geochronologic glacial/deglacial events are identified. Till sheets (Till units I-IV) interbedded with marine sediments (Marine units I-IV), exposed in superposition in stratigraphical sections, and raised beach sequences at altitudes up to $140 \mathrm{ma}$ a.s.l., relate to repeated glacial loading by Kara Sea-based ice sheets.

(iii) Careful assessment of an extensive dating program (AMS ${ }^{14} \mathrm{C}$, electron spin resonance, green stimulated luminescence, and Aspartic Acid geochronology) shows major glaciations followed by deglaciation and marine inundation during MIS 10-9, MIS 8-7, MIS 65e and MIS 5d-3.

(iv) There is a noticeable lack of till and raised marine evidence for Late Weichselian glaciation of Severnaya Zemlya, which is consistent with previous assessments concluding restricted glaciations in the Kara Sea during MIS 2 (Raab et al., 2003; Svendsen et al., 2004; Siegert and Dowdeswell, 2004).

(v) Structural and textural evidence from tills and sub-till sediments on southern October Revolution Island suggest that ice repeatedly advanced from the north implying expanding, wet-based local ice caps from Severnaya Zemlya towards the Kara Sea.

(vi) The build-up of local icecaps on the Severnaya Zemlya archipelago, and probably in several other areas along the perimeter of the Kara Sea, reflect the initiation 
stage of a Kara Sea Ice Sheet. Local ice caps during the inception phases were wet-based as indicated by till deposition and subglacial deformation, whereas the lack of tills associated with Kara Sea Ice Sheets reflects cold-based ice sheet coverage at a later stage in the glacial cycle. The presence of raised beaches up to $140 \mathrm{~m}$ reflects regional isostatic deformation with ice sheet loading of $>2000 \mathrm{~m}$ (Lambeck et al., submitted) over the Kara Sea shelf and large-scale glaciation of the Eurasian North.

\section{Acknowledgements}

The Swedish part of this work has been financially supported by a grant from the Swedish Research Council (VR), given to Ó. Ingólfsson and P. Möller (Contract No. G-5103-20005347/2000) and is a contribution to the EU and ESF-supported project "Quaternary Environments of the Eurasian North" (QUEEN). The American contribution was supported by US National Science Foundation collaborative grants NSF OPP 0196182 and NSF OPP 0001885 to D. Lubinski and S. Forman, respectively. This project is a contribution to the NSF RAISE program sponsored by the Office of Polar Programs and ARCSS. The logistics for the 2002 and 2003 expeditions were planned and financed by the Swedish Polar Research Secretariat and the US National Science Foundation. Logistics was provided through subcontracts to INTAARI and CERPOLEX. Svend Funder, Geological Museum, Copenhagen, Denmark determined mollusc species. Anatoly Molodkov, Tallin Technical University, Estonia, performed ESR datings and provided background information on ESR dating. Darrell Kaufman, Department of Geology, Northern Arizona University provided amino acid geochronology on shell samples. Henning Lorenz, Department of Earth Sciences, Uppsala, Sweden, collaborated on satellite and aerial imagery and assisted with logistics in 2003. Svend Meldgaard Christiansen and Jette Gissel Nielsen, Department of Earth Sciences, University of Aarhus, Denmark, carried out the laboratory treatment of most samples for foraminiferal analyses. Tatiana Dmitrieva at the "All Russian oil geology Institute," St. Petersburg, Russia, carried out foraminiferal analyses of sections $\mathrm{Oz} 1 \mathrm{y}$ and 1z. Skilled helicopter crews from Khatanga safely transported us sometimes in trying conditions. QSR reviewers Kurt Kjær, Copenhagen University, Denmark, and Jan Mangerud, University of Bergen, Norway, gave positive and valuable suggestion for improving this work. To all these organizations and persons we proffer our sincere gratitude.

\section{References}

Alexanderson, H., Hjort, C., Bolshiyanov, D.Yu., Möller, P., Antonov, O., Fedorov, G.B., Pavlov, M., 2001. The North Taymyr ice-marginal zone - a preliminary overview and dating. Global and Planetary Change 31, 427-445.

Alexanderson, H., Adrielsson, L., Hjort, C., Möller, P., Antonov, O., Eriksson, S., Pavlov, M., 2002. The depositional history of the North Taymyr ice-marginal zone, Siberia - a landsystem approach. Journal of Quaternary Science 17, 361-382.

Andreev, A.A., Nikolaev, V.I., Bolshiyanov, D.Yu., Petrov, V.N., 1997. Pollen and isotope investigations of an ice core from Vavilov Ice Cap, October Revolution Island, Severnaya Zemlya Archipelago, Russia. Geographie Physique et Quaternaire 51, 379-389.

Arkhipov, S.A., 1989. A chronostratigraphic scale of the glacial Pleistocene of the West Siberian North. In: Skabichevskaya, N.A. (Ed.), Pleistotsen Sibiri. Stratigrafia i Mezhregionalnye Korrelatsii. Nauka, Novosibirsk, pp. 19-30 (in Russian).

Arkhipov, S.A., Isayeva, L.L., Bespaly, V.G., Glushkova, O., 1986. Glaciation of Siberia and North-East USSR. Quaternary Science Reviews 5, 463-474.

Astakhov, V.I., 1998. The last ice sheet of the Kara Sea: terrestrial constraints on its age. Quaternary International 45/46, 19-28.

Astakhov, A., 2001. The stratigraphic framework for the Upper Pleistocene of the glaciated Russia: changing paradigms. Global and Planetary Change 31, 283-295.

Astakhov, A., 2004a. Middle Pleistocene glaciations of the Russian North. Quaternary Science Reviews 23, 1285-1311.

Astakhov, A., 2004b. Pleistocene ice limits in the Russian northern lowlands. In: Ehlers, J., Gibbard, P.L. (Eds.), Quaternary Glaciations-Extent and Chronology. Part 1: Europe, Developments in Quaternary Science, vol. 2A. Elsevier, Amsterdam, pp. 309-319.

Benn, D.I., 1995. Fabric signature of subglacial till deformation, Breidamerkurjökull, Iceland. Sedimentology 42, 735-747.

Benn, D.I., Evans, J.A., 1996. The interpretation and classification of subglacially deformed materials. Quaternary Science Reviews 15, 23-52.

Berger, G.N., Melles, M., Banerjee, D., Murray, A.S., Raab, A., 2004. Luminescence chronology of non-glacial sediments in Changeable Lake, Russian High Arctic, and implications for limited Eurasian icesheet extent during the LGM. Quaternary Science Reviews 19, 513-523.

Blieck, A.R.M., Karatajute-Talima, V.N., Mark-Kurik, E., 2002. Upper Silurian and Devonian heterostracan teraspidomorphs (Vertebrata) from Severnaya Zemlya (Russia): a preliminary report with biogeographical and biostratigraphical implications. Geodiversitas 24, 805-820.

Bolshiyanov, D.Yu., Makeyev, V.M., 1995. Arkhipelag Severnaya Zemlya: oledeneniye, istoria razvitia prirodnoi sredy (Severnaya Zemlya Archipelago: Glaciation, Environmental History). Gidrometeoizdat, St. Petersburg, 215pp. (in Russian).

Bolshiyanov, D.Yu., Molodkov, A., 1998. Marine Pleistocene deposits of the Taymyr Peninsula and their age from ESR dating. In: Kassens, H., Bauch, I., Dmitrenko, H., Eicken, H., Hubberten, H.-W., Melles, M., Thiede, J., Timokhov, L. (Eds.), Land-Ocean Systems in the Siberian Arctic: Dynamics and History. Springer, Berlin, pp. 469-475.

Boulton, G.S., Hindmarsh, R.C.A., 1987. Sediment deformation beneath glaciers: rheology and sedimentological consequences. Journal of Geophysical Research 92, 9059-9082.

Bouma, A.H., 1962. Sedimentology of Some Flysch Deposits: A Graphic Approach to Facies Interpretation. Elsevier, Amsterdam (168pp.).

Brumby, S., Yoshida, H., 1994. ESR dating of mollusc shell: investigations with modern shell of four species. Quaternary Science Reviews 13, $157-162$.

Bude, S.-O., 1997. Artengemeinschaften bentischer Foraminifeen in der Laptev-See, sibirische Arktis: Rezente Verteilungsmuster und Ökologie. M.Sc. Thesis, Christian-Albrecht-Universität zu Kiel, 60pp.

Elliot, T., 1986. Siliscastic shorelines. In: Reading, H.G. (Ed.), Sedimentary Environments and Facies, second ed. Blackwell Scientific, Oxford, pp. $155-188$. 
England, J., 1999. Coalescent Greenland and Innuitian ice during the Last Glacial maximum: revising the Quaternary of the Canadian High Arctic. Quaternary Science Review 18, 421-456.

Eyles, N., Eyles, C.H., Miall, A.D., 1983. Lithofacies types and vertical profile models; an alternative approach to the description and environmental interpretation of glacial diamict and diamictite sequences. Sedimentology 30, 393-410.

Fain, J., Soumana, S., Montret, M., Miallier, D., Pilleyre, T., Sanzelle, S., 1999. Luminescence and ESR dating-beta-dose attenuation for various grain shapes calculated by a Monte-Carlo method. Quaternary Science Reviews 18, 231-234.

Feyling-Hanssen, R.W., 1983. Quantitative methods in micropaleontology. In: Costa, L.I. (Ed.), Palynology-Micropalaeontology: Laboratories, Equipment and Methods. Norwegian Petroleum Directorate Research Bulletin, vol. 2, pp. 109-128.

Fisher, E.L., Leonov, B.N., Nikolskaya, M.Z., Petrov, O.M., Ratsko, A.P., Sulerzhitsky, L.D., Cherkasova, M.N., 1990. The Late Pleistocene of the central North-Siberian Lowland. Izvestiya Academii Nauk SSSR, Seriya Geograficheskayua 6, 109-118 (in Russian).

Forman, S.L., 1999. Infrared and red stimulated luminescence dating of late Quaternary near shore sediments from Spitsbergen, Svalbard. Arctic, Antarctic and Alpine Research 31, 4-49.

Forman, S.L., Polyak, L., 1997. Radiocarbon content of pre-bomb marine molluscs and variations in the ${ }^{14} \mathrm{C}$ reservoir age for coastal areas of the Barents and Kara seas, Russia. Geophysical Research Letters 24, $885-888$.

Forman, S.L., Ingólfsson, Ó., Gataullin, V., Manley, W.F., Lokrantz, H., 1999. Late Quaternary stratigraphy of western Yamal Peninsula, Russia: new constraints on the configuration of the Eurasian ice sheet. Geology 27, 807-810.

Forman, S.L., Maslowski, W., Andrews, J.T., Lubinski, D., Steele, M., Zhang, J., Lammers, R., Peterson, B., 2000. Researchers explore Arctic freshwater's role in ocean circulation. EOS, Transactions, American Geophysical Union 81, 169-174.

Forman, S.L., Ingolfsson, O., Gataullin, V., Manley, W., Lokrantz, H., 2002. Late quaternary stratigraphy, glacial limits, and paleoenvironments of the marresale area, Western Yamal Peninsula, Russia. Quaternary Research 57, 355-370.

Funder, S., Demidov, I., Yelovicheva, Y., 2002. Hydrography and mollusc faunas of the Baltic and the White Sea-North Sea seaway in the Eemian. Palaeogeography, Palaeoclimatology, Palaeoecology 184, 275-304.

Grosswald, M.G., 1998. Late-Weichselian ice sheets in Arctic and Pacific Siberia. Quaternary International 45/46, 3-18.

Gudina, V.I., Evzerov, V.Ya., 1973. The stratigraphy and foraminifera of the Upper Pleistocene in the Kola Peninsula. Geologiya i Geofizika 175, 1-146 (in Russian).

Gudina, V.I., Levchuk, L.K., 1989. Fossil and modern Elphidiids of arctic and boreal regions: morphology and taxonomic classification. Journal of Foraminiferal Research 19, 20-37.

Hald, M., Steinsund, P.I., 1992. Distribution of surface sediment benthic foraminifera in the southwestern Barents Sea. Journal of Foraminiferal Research 22 (4), 347-362.

Hart, J.K., 1994. Till fabric associated with deformable beds. Earth Surface Processes and Landforms 19, 15-32.

Hart, J.K., Rose, J., 2001. Approaches to the study of glacier bed deformation. Quaternary International 86, 45-58.

Hjort, C., Fedorov, G., Funder, S., Onishev, A., 2003. Taymyr Quaternary geology 2002 - the glaciers did not always come from the Kara Sea. In: Rickberg, S. (Ed.), Polarforskningssekretariatet. Årsbok, pp. 80-84.

Hjort, C., Möller, P., Alexanderson, H., 2004. Weichselian glaciation of the Taymyr Peninsula, Siberia. In: Ehlers, J., Gibbard, P.L. (Eds.), Quaternary Glaciations-Extent and Chronology. Part 1: Europe, Developements in Quaternary Science, vol. 2A. Elsevier, Amsterdam, pp. 359-367.

Jakobsson, M., Cherkis, N., Woodward, J., Coakley, B., Macnab, R., 2000. A new grid of Arctic bathymetry: a significant resource for scientists and mapmakers. EOS Transactions, American Geophysical Union 81 (9), 89 93, 96.

Jakobsson, M., Løvlie, R., Arnold, E.M., Backman, J., Polyak, L., Knutsen, J.-O., Musatov, E., 2001. Pleistocene stratigraphy and palaeoenvironmental variation from Lomonosov Ridge sediments, central Arctic Ocean. Global and Planetary Change 31, 1-22.

Jain, M., Botter-Jensen, L., Singhvi, A.K., 2003. Dose evaluation using multiple-aliquot quartz OSL: test of methods and a new protocol for improved accuracy and precision. Radiation Measurements 37, 67-80.

Kaufman, D.S., Manley, W.F., 1998. A new procedure for determining DL amino acid ratios in fossils using reverse phase liquid chromatography. Quaternary Science Reviews 17, 987-1000.

Kind, N.V., Leonov, B.N. (Eds.), 1982. Antropogen Taymyra (The Antropogene of the Taymyr Peninsula). Nauka, Moscow (184pp.) (in Russian).

Knies, J., Kleiber, H.-P., Matthiessen, J., Müller, C., Nowaczyk, N., 2001. Marine ice-rafted debris records constraining the maximum extent of Saalian and Weichselian ice-sheets along the northern Eurasian margin. Global and Planetary Change 31, 45-64.

Kotlyakov, V.M., Arkhipov, S.M., Henderson, K.A., Nagornov, O.V., 2004. Deep drilling of glaciers in Eurasian Arctic as a source of paleoclimatic records. Quaternary Science Reviews 23, 1371-1390.

Lambeck, K., Chappell, J., 2001. Sea level change trough the last glacial cycle. Science 292, 679-686.

Lambeck, K., Purcell, A., Funder, K., Kjær, K.H., Möller, P. (in press). The Eurasian ice sheet from Late Saalian to Early Middle Weichselian constrained by field data and rebound modelling. Boreas.

Lokrantz, H., Ingólfsson, Ó., Forman, S.L., 2003. Glaciotectonised quaternary sediments at Cape Shpindler, Yugorski Peninsula, Arctic Russia: implications for glacial history, ice-movements and Kara Sea ice sheet configuration. Journal of Quaternary Research 18, $527-543$.

Lorange, K., 1977. En mikropaleontologisk-stratigrafisk undersøkelse av kvartære sedimenter i nordvestre del av Barentshavet. M.Sc. Thesis, Geological Institute, University of Oslo, Norway, 237pp.

Lowe, D.R., 1982. Sediment gravity flows: II. Depositional models with special reference to the deposition of high-density turbidity currents. Journal of Sedimentary Petrology 52, 279-297.

Lykke-Andersen, A.-L., 1987. A Late Saalian, Eemian and Weichselian marine sequence at Nørre Lyngby, Vendsyssel, Denmark. Boreas 16, 345-357.

Mackensen, A., 1997. Zur Paläoozeanographie hoher Breiten: stellvertreterdaten aus foraminiferen. Berichte zur Polarforschung 243, 1-146 (in German).

Mackensen, A., Schmiedl, G., Harloff, J., Giese, M., 1995. Deep-sea foraminifera in the south Atlantic Ocean: ecology and assemblage generation. Micropaleontology 41 (4), 342-358.

Makeyev, V.M., Bolshiyanov, D.Yu., 1986. Formation of the relief and deposits in areas of present-day glaciation on Severnaya Zemlya. Polar Geography and Geology 10, 331-338.

Makeyev, V.M., Arslanov, K.A., Garutt, V.Y., 1979. Age of mammoths of Severnaya Zemlya and some aspects of Late Pleistocene paleogeography. Doklady Academii Nauk SSSR 245, 421-424 (in Russian).

Makeyev, V.M., Bolshiyanov, D.Yu., Malakhovskiy, D.B., Baranskaya, A.I., Ponomareva, D.P., 1992. Stratigraphy and geochronology of the Pleistocene deposits of Severnaya Zemlya. Geokhronologiya Chetvertichnogo Periots, 132-137 (in Russian).

Mangerud, J., Gulliksen, S., 1975. Apparent radiocarbon ages of recent marine shells from Norway, Spitsbergen, and Arctic Canada. Quaternary Research 5, 263-273.

Mangerud, J., Bolstad, M., Elgersma, A., Helliksen, D., Landvik, J.Y., Lønne, I., Lycke, A.K., Salvigsen, O., Sandahl, R., Svendsen, J.I., 1992. The last glacial maximum on Spitsbergen, Svalbard. Quaternary Research 38, 1-31.

Mark, D.M., 1973. Analysis of axial orientation data, including till fabrics. Geological Society of America Bulletin 84, 1369-1374.

Mejdahl, V., Christiansen, H.H., 1994. Procedures used for luminescence dating of sediments. Boreas 13, 403-406. 
Möller, P., Bolshiyanov, D.Yu., Bergsten, H., 1999a. Weichselian geology and palaeoenvironmental history of the central Taymyr Peninsula, Siberia, indicating no glaciation during the last global glacial maximum. Boreas 28, 92-114.

Möller, P., Bolshiyanov, D.Yu., Jansson, U., Schneider, G.V., 1999b. The "Ledyanaya gravel event"- a marker of the last glacioisostaticinduced depression along the Byrranga Mountains and south thereof. Abstract. Quaternary Environments of the Eurasian North (QUEEN), Third QUEEN Workshop, Øystese, Norway, 17-18 April 1999, p. 41.

Möller, P., Fedorov, G., Pavlov, M., Seidenkrantz, M.-S., Sparrenbom, C. (in prep). Glacial and palaeoenvironmental history of the northern Taymyr Peninsula, arctic Siberia.

Molodkov, A., 1988. ESR dating of quaternary shells: recent advances. Quaternary Science Reviews 7, 477-484.

Molodkov, A.N., Bolikhovskaya, N.S., 2002. Eustatic sea-level and climate changes over the last $600 \mathrm{ka}$ as derived from mollusc-based ESR-chronostratigraphy and pollen evidence in Northern Eurasia. Sedimentary Geology 150, 185-201.

Molodkov, A., Dreimanis, A., Ăboltiņš, O., Raukas, A., 1998. The ESR age of Portlandia arctica shells from glacial deposits of Central Latvia: an answer to a controversy on the age and genesis of their enclosing sediments. Quaternary Science Reviews 17, 1077-1094.

Nemec, W., 1990. Aspects of sediment movement on steep delta slopes. In: Colella, A., Prior, D.P. (Eds.), Coarse-Grained Deltas, vol. 10. International Association of Sedimentologists Special Publication, UK, pp. 29-73.

Niessen, F., Weiel, D., Ebel, T., Hahne, J., Kopsch, C., Melles, M., Musatov, E., Stein, R., 1997. Weichselian glaciation in central Siberia-implications from marine and lacustrine high resolution seismic profiles and sediment cores. EUG 9 Conference Strasbourg, France. Terra Nova 9, Abstract Supplement 1, p. 208.

Olsson, I.U., 1980. Content of ${ }^{14} \mathrm{C}$ in marine mammals from northern Europe. Radiocarbon 22, 662-675.

Peltier, W.R., 1994. Ice age paleotopography. Science 265, 195-201.

Polyak, L., Edwards, M.H., Coakley, B.J., Jakobsson, M., 2001. Ice shelves in the Pleistocene Arctic Ocean inferred from glaciogenic deepsea bedforms. Nature 410, 453-457.

Polyak, L., Korsun, S., Febo, L.A., Stanovoy, V., Khusid, T., Hald, M., Paulsen, B.E., Lubinski, D.J., 2002. Benthic foraminiferal assemblages from the southern Kara Sea, a river-influenced arctic marine environment. Journal of Foraminiferal Research 32, 252-273.

Porsild, M.P., 1918. On "savssats" - a crowding of arctic animals at holes in the sea ice. Geographical Review 6, 215-228.

Prescott, J.R., Hutton, J.T., 1994. Cosmic ray contributions to dose rates for luminescence and ESR dating: large depths and long-term time variations. Radiation Measurements 23, 497-500.

Raab, A., Melles, M., Berger, G.W., Hagedorn, B., Hubberten, H.-W., 2003. Non-glacial paleoenvironments and the extent of Weichselian ice sheets on Severnaya Zemlya, Russian High Arctic. Quaternary Science Reviews 22, 2267-2283.

Richardson, C.A., 1994. Effects of bleaching on the sensitivity to dose of the infrared-stimulated luminescence of potassium-rich feldspars from Ynyslas, Wales. Radiation Measurements 23 (2-3), 587-591.

Rosing, J., 1986. Havets Enhjørning. Wormanium, Højbjerg, Denmark (82pp.).

Saks, V.N., 1953. The Quaternary Period in the Soviet Arctic. (Chetvertichny period v Sovietskoi Arktike). Vodtransizdat, Leningrad, Moscow (627pp.) (in Russian).

Schellmann, G., Radtke, U., 1997. Electron spin resonance (ESR) techniques applied to mollusc shells from South America (Chile, Argentina) and implications for palaeo sea-level curve. Quaternary Science Reviews 16, 465-475.
Seidenkrantz, M.-S., 1993. Benthic foraminiferal and stable isotope evidense for a "Younger Dryas-style" cold spell at the Saalian-Eemian transition, Denmark. Palaeogeography, Palaeoclimatology, Palaeoecology 102, 103-120.

Siegert, M.J., Dowdeswell, J.A., 2004. Numerical reconstructions of the Eurasian Ice Sheet and climate during the Late Weichselian. Quaternary Science Reviews 23, 1273-1283.

Siegert, M.J., Dowdeswell, J.A., Svendsen, J.I., Elverhøi, A., 2002. The Eurasian Arctic during the last ice age. American Scientist 90, 32-39.

Singhvi, A.K., Sharma, Y.P., Agrawal, D.P., 1982. Thermoluminescence dating of dune sands in Rajasthan, India. Nature 295, 313-315.

Spielhagen, R.F., Bauman, K.-H., Erlenkeuser, H., Nowaczyk, N.R., Nørgaard-Pedersen, N., Vogt, S., Weiel, D., 2004. Arctic Ocean deepsea records of northern Eurasian ice sheet history. Quaternary Science Reviews 23, 1455-1483.

Stafford Jr., T.W., Hare, P.E., Currie, L., Jull, A.J.T., Donahue, D.J., 1991. Accelerator radiocarbon dating at the molecular level. Journal of Archaeological Science 18, 35-72.

Steinsund, P.I., Polyak, L., Hald, M., Mikhailov, V., Korsun, S., 1994. Distribution of calcareous benthic foraminifera in recent sediments of the Barents and Kara Sea. In: Steinsund, P.I. (Ed.), Benthic Foraminifera in Surface Sediments of the Barents and Kara Seas: Modern and Late Quaternary Application. Ph.D. Thesis, Department of Geology, Institute of Biology and Geology, University of Tromsø, Norway.

Svendsen, J.I., Alexanderson, H., Astakhov, V.I., Demidov, I., Dowdeswell, J.A., Funder, S., Gataullin, V., Henriksen, M., Hjort, C., Houmark-Nielsen, M., Hubberten, H.W., Ingólfsson, Ó., Jakobsson, M., Kjær, K.H., Larsen, E., Lokrantz, H., Lunka, J.P., Lysa, A., Mangerud, J., Matiouchkov, A., Murray, A., Möller, P., Niessen, F., Nikolskaya, O., Polyak, L., Saarnisto, M., Siegert, C., Siegert, M.J., Spielhagen, R.F., Stein, R., 2004. Late quaternary ice sheet history of northern Eurasia. Quaternary Science Reviews 23, 1229-1271.

Taylor, R.E., 1987. Radiocarbon Dating: An Archaeological Perspective. Academic Press, New York (212pp.).

Urvantsev, N.N., 1931. Quaternary glaciation of Taymyr. Bulleten Komissii po Izucheniyu Chetvertichnogo Perioda 3, 23-42 (in Russian).

Vaikmäe, R., Punning, Y.-M.K., Romanov, V.V., Barkov, N.I., 1988. Stratigraphy of the Vavilov Ice Dome in Severnaya Zemlya using isotopic geochemical methods. Data of Glaciological Studies 40, 127-135.

Velichko, A.A., Isayeva, L.L., Makeyev, V.M., Matishov, G.G., Faustova, M.A., 1984. Late Pleistocene glaciation of the Arctic Shelf, and the reconstruction of Eurasian ice sheets. In: Velichko, A.A., Wright, H.E., Barnosky, C.W. (Eds.), Late Quaternary Environments of the Soviet Union. University of Minnesota Press, Minneapolis, pp. $35-41$.

van der Plicht, J., Beck, J.W., Bard, E., Baillie, M.G.L., Blackwell, P.G., Buck, C.E., Friedrich, M., Guilderson, T.P., Hughen, K.A., Kromer, B., McCormac, F.G., Ramsey, C.B., Reimer, P.J., Reimer, R.W., Remmele, S., Richards, D.A., Southon, J.R., Stuiver, M., Weyhenmeyer, C.E., 2004. NotCal04 comparison/calibration ${ }^{14} \mathrm{C}$ records 26-50 cal kyr BP. Radiocarbon 46 (3), 1225-1238.

Volkova, V.S., Babushkin, A.Ye., 2000. Unifitsirovannaya Regionalnaya Stratigraficheskaya Skhema Chetvertichnykh Otlozheniy ZapadnoSibirskoi Ravniny (The Unified Regional Stratigraphic Scheme of the Quaternary of the West Siberian Plain). SNIIGGiMS, Novisibirsk (64pp.) (in Russian).

Weaver, A.J., 1995. Driving the ocean conveyor. Nature 378, 135-136. 